\title{
Databases Available in the National Institute of Standards and Technology Research Library
}

\section{Diane Cunningham}

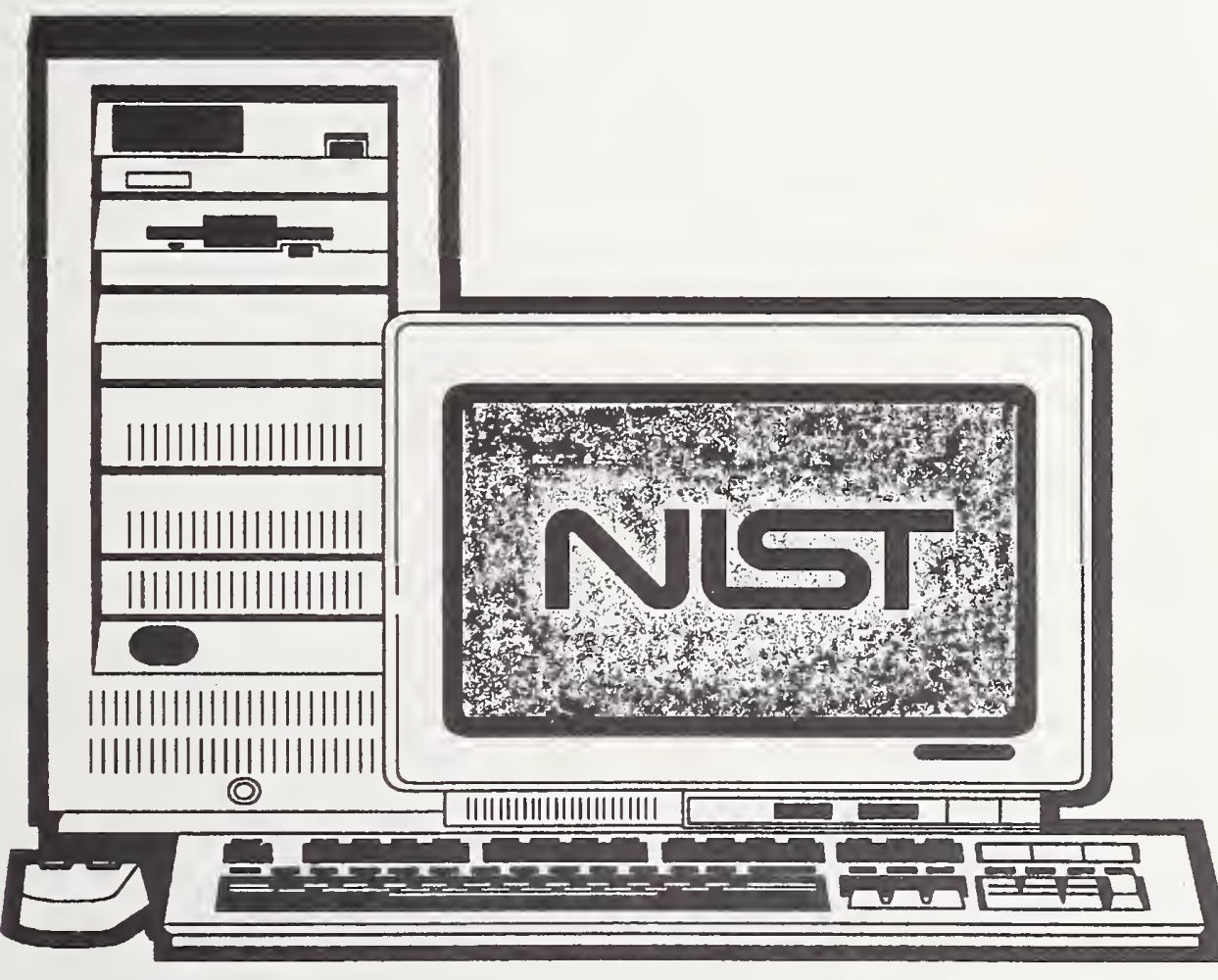


$T$ he National Institute of Standards and Technology was established in 1988 by Congress to "assist industry in the development of technology ... needed to improve product quality, to modernize manufacturing processes, to ensure product reliability ... and to facilitate rapid commercialization ... of products based on new scientific discoveries."

NIST, originally founded as the National Bureau of Standards in 1901, works to strengthen U.S. industry's competitiveness; advance science and engineering; and improve public health, safety, and the environment. One of the agency's basic functions is to develop, maintain, and retain custody of the national standards of measurement, and provide the means and methods for comparing standards used in science, engineering, manufacturing, commerce, industry, and education with the standards adopted or recognized by the Federal Government.

As an agency of the U.S. Commerce Department's Technology Administration, NIST conducts basic and applied research in the physical sciences and engineering, and develops measurement techniques, test methods, standards, and related services. The Institute does generic and precompetitive work on new and advanced technologies. NIST's research facilities are located at Gaithersburg, MD 20899, and at Boulder, CO 80303. Major technical operating units and their principal activities are listed below. For more information contact the Publications and Program Inquiries Desk, 301-975-3058.

Office of the Director

- National Quality Program

- International and Academic Affairs

Technology Services

- Standards Services

- Technology Partnerships

- Measurement Services

- Technology Innovation

- Information Services

\section{Advanced Technology Program}

- Economic Assessment

- Information Technology and Applications

- Chemical and Biomedical Technology

- Materials and Manufacturing Technology

- Electronics and Photonics Technology

\section{Manufacturing Extension Partnership Program \\ - Regional Programs \\ - National Programs \\ - Program Development}

\section{Electronics and Electrical Engineering}

\section{Laboratory}

- Microelectronics

- Law Enforcement Standards

- Electricity

- Semiconductor Electronics

- Electromagnetic Fields'

- Electromagnetic Technology'

- Optoelectronics'

\section{Chemical Science and Technology Laboratory \\ - Biotechnology \\ - Physical and Chemical Properties ${ }^{2}$ \\ - Analytical Chemistry \\ - Process Measurements \\ - Surface and Microanalysis Science}

Physics Laboratory

- Electron and Optical Physics

- Atomic Physics

- Optical Technology

- Ionizing Radiation

- Time and Frequency ${ }^{1}$

- Quantum Physics'

\section{Materials Science and Engineering} Laboratory

- Intelligent Processing of Materials

- Ceramics

- Materials Reliability'

- Polymers

- Metallurgy

- NIST Center for Neutron Research

\section{Manufacturing Engineering}

Laboratory

- Precision Engineering

- Automated Production Technology

- Intelligent Systems

- Fabrication Technology

- Manufacturing Systems Integration

Building and Fire Research Laboratory

- Structures

- Building Materials

- Building Environment

- Fire Safety Engineering

- Fire Science

\section{Information Technology Laboratory}

- Mathematical and Computational Sciences ${ }^{2}$

- Advanced Network Technologies

- Computer Security

- Information Access and User Interfaces

- High Performance Systems and Services

- Distributed Computing and Information Services

- Software Diagnostics and Conformance Testing

\footnotetext{
${ }^{1}$ At Boulder, CO 80303.

${ }^{2}$ Some elements at Boulder, CO.
} 


\section{NIST Special Publication 927}

\section{Databases Available in the National Institute of Standards and Technology Research Library}

Diane Cunningham

Office of Information Services

National Institute of Standards and Technology

Gaithersburg, MD 20899-0001

February 1998

Supersedes NIST Special Publication 909 (December 1996)

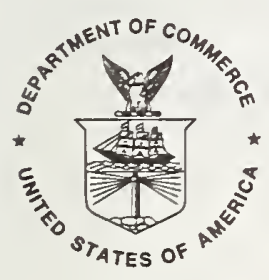

U.S. Department of Commerce

William M. Daley, Secretary

Technology Administration

Gary R. Bachula, Under Secretary for Technology

National Institute of Standards and Technology

Raymond G. Kammer, Director 
National Institute of Standards and Technology

Special Publication 927

Natl. Inst. Stand. Technol.

Spec. Publ. 927

Supersedes NIST Spec. Publ. 909

149 pages (Feb. 1998)

CODEN: NSPUE2
U.S. Government Printing Office Washington: 1998

For sale by the Superintendent of Documents U.S. Government Printing Office Washington, DC 20402 


\section{FOREWORD}

The mission of the Office of Information Services (OIS) is "to support and enhance the research activities of the NIST Scientific and Technological community through a comprehensive program of knowledge management. To constantly improve and increase information collection and dissemination to meet the needs of the broadest possible audience. To deliver superior and timely service through a trained, responsive, and professional staff."

In fulfilling this mission, the OIS NIST Research Library collects and supports information resources regardless of the form in which they appear or the source from which they emanate. Recognizing that the NIST Research Library cannot collect all knowledge, it seeks to augment its collections by identifying and providing access to a broad variety of bibliographic and full-text databases. Access is provided through subscriptions to vendor services, such as The Dialog Corporation, ${ }^{1}$ or by the acquisition of databases. The NIST Research Library supports access through the services of research consultants specially trained to assist the NIST technical staff in formulating and carrying out searches, thereby facilitating effective and efficient use of the databases.

In addition, the OIS has initiated a NIST Virtual Library Program (NVL) providing NIST-wide online access from the staff's desktop computer to a variety of information resources and services, regardless of the form or the source of the information. Through special licensing agreements, the NVL is providing access from the desktop to a selection of these databases, which, in some cases, facilitate or provide online desktop access to the full text of the desired information. For example, Computer Select is a database providing access to the abstracts or full text of articles from a selection of journals covering computer technology, the industry, and consumer news. This is available for use in the NIST Research Library, and is accessible on the desktop by networking the CD-ROM on the NVL. Through an agreement with the Online Computer Library Center (OCLC), the NVL provides access to bibliographic citations to articles, and in some cases to the full text of articles, in over 9,000 journals included through the Article First service. The capability of online ordering of the journal articles is also provided. In addition, the Web of Science provides access to references and abstracts from scientific journals.

This publication lists databases by acronyms and full titles. Citations also include dates covered, brief descriptions, kinds of information each contains, producers, the titles of corresponding hard copy, and vendors. (Databases in the LEXIS/NEXIS service are too numerous to mention individually in this report.) An asterisk $(*)$ in the vendor's column denotes availability of the CD-ROM format of the database in the NIST Research Library. A list of vendors with addresses and telephone numbers precedes the list.

The General Subject Index is arranged alphabetically by subject categories, and the Cross Reference Index lists variant forms of the names of the databases in the left column with cross references to the name of the database used in this publication on the right. A list of Full Text Databases is also included.

Following the main database list, is a separate list of databases available on CD-ROM.

If you are interested in a literature search, call 301/975-3052 or see a Research Consultant in the NIST Research Library. For additions or changes that have occurred since the publication of this report, please contact a Research Consultant.

This publication supersedes and revises NIST SP 909, which is dated December 1996.

I wish to thank Karen Wick for her able assistance and diligence in preparing this publication.

Diane Cunningham

Research Consultant

\footnotetext{
${ }^{1}$ The identification in this report of certain commercial products is not intended to imply recommendation or endorsement by the National Institute of Standards and Technology, nor that the products are necessarily the best available for the purpose.
} 



\section{CONTENTS}

Foreword $\ldots \ldots \ldots \ldots \ldots \ldots \ldots \ldots \ldots \ldots \ldots \ldots \ldots \ldots \ldots \ldots \ldots \ldots \ldots$ iii

Vendors/Database Inquiries......................... vii

List of Databases............................

Databases on CD-ROM........................... 104

General Subject Index..................... 106

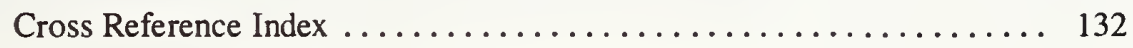

Full Text Databases............................ 139 



\section{VENDORS/DATABASE INQUIRIES}

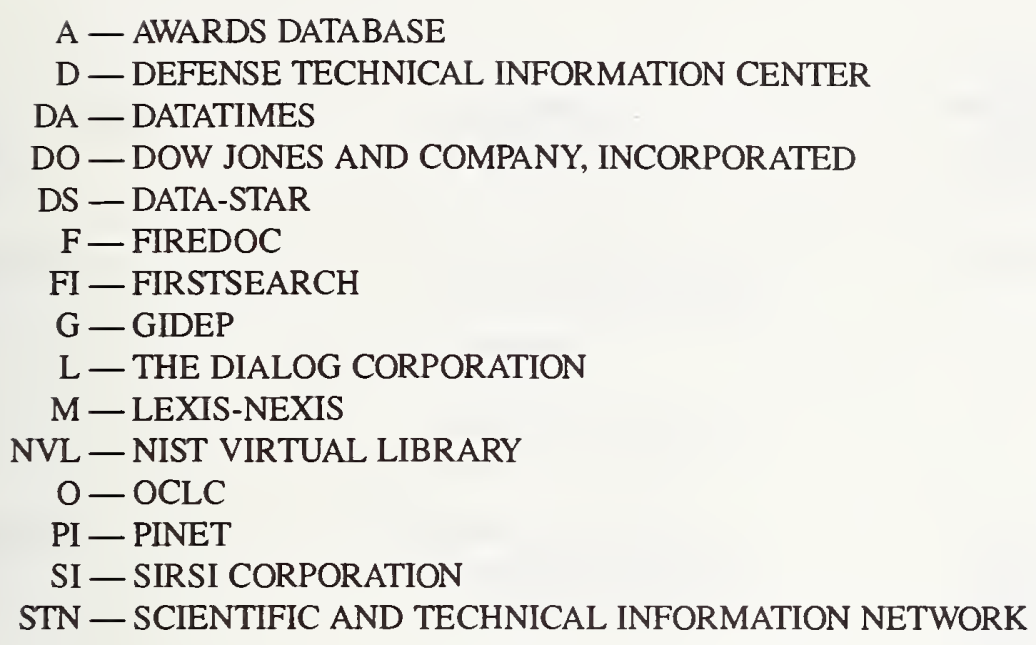

A - AWARDS DATABASE Sami Klein

NIST Research Library

National Institute of Standards and Technology

Bldg. 101 Room E124

Gaithersburg, Maryland 20899

(301) $975-2790$

D - Defense Technical Information Center Defense RDT \& E OnLine System (DROLS) 8725 John J. Kingman Road Suite 0944

Ft. Belvoir, Virginia 22060-6218

(703) $767-8222$

DA - UMUDataTimes 14000 Quail Springs Parkway

Suite 450

Oklahoma City, Oklahoma 73134-2613

(800) 642-2525

(405) $751-6400$

DO - Dow Jones and Company, Incorporated P.O. Box 300

Princeton, New Jersey 08543-0300

(800) 369-7466

DS - Data-Star The Dialog Corporation 2440 W. El Camino Real Mountain View, California 94040

(800) 334-2564

(415) 2548800
F - FIREDOC

Nora H. Jason

Fire Research Information Service

Building and Fire Research Laboratory

National Institute of Standards and Technology

A252 Polymer Bldg.

Gaithersburg, Maryland 20899

(301) 975-6862

FI - FIRSTSEARCH

OCLC

6565 Frantz Road

Dublin, Ohio 43017-3395

(800) $848-5878$

(614) 764-6000

G - Government-Industry Data Exchange Program 2300 Fifth Street

Norco, California 91760

(909) 273-4677

L - The Dialog Corporation 2440 W. El Camino Real

Mountain View, California 94040

(800) 334-2564

(415) $254-8800$

$M$ - LEXIS-NEXIS

P.O. Box 933

Dayton, Ohio 45401-0933

(800) $227-4908$

(937) 859-1608 


\section{VENDORS/DATABASE INQUIRIES}

NVL — NIST Virtual Library William Trefzger NIST Research Library Bldg. 101 Room E216 Gaithersburg, Maryland 20899 (301) 975-2146

$\mathrm{O}-\mathrm{OCLC}$ 6565 Frantz Road Dublin, Ohio 43017-3395

(800) 848-5878

(614) $764-6000$

PI — PINET

American Institute of Physics Electronic Publishing Division 500 Sunnyside Blvd.

Woodbury, New York 11797-2999

(516) $576-2262$

SI - SIRSI CORPORATION

STILAS System

William Trefzger

NIST Research Library

National Institute of Standards and Technology Bldg. 101 Room E216

Gaithersburg, Maryland 20899

(301) 975-2146

STN - STN International c/o Chemical Abstracts Service 2540 Olentangy River Road

P.O. Box 3012

Columbus, Ohio 43210-0012

(800) 848-6533

(614) 447-3698 


\section{DATABASES AVAILABLE IN THE NATIONAL INSTITUTE OF STANDARDS AND TECHNOLOGY (NIST) RESEARCH LIBRARY}

DATABASE AND DATES

COVERED

A-V ONLINE

1964
DESCRIPTION/

PRINCIPAL SOURCES
PRODUCER AND

HARD COPY COUNTERPART
VENDOR AND/OR

DATABASE INQUIRIES
Nonprint media covering all

levels of education and

instruction/

Audiovisual materials

$\begin{array}{ll}\text { ABC EUROPE } & \text { Detailed information on } \\ \text { Current } & 149,000 \text { companies in } 32 \\ & \text { European countries/ }\end{array}$

ABC EUROPE

European countries/
Access Innovations, Incorporated L

$\mathrm{L}$
ABC der Deutschen Wirtschaft

Verlagsgesellschaft $\mathrm{mbH}$ and Europe Export Edition GmbH (Germany)

\section{ABI/INFORM}

1971-
Literature on all phases of business management and ad-

ministration including accounting, data processing, finance, market-

ing, and production/

Journals
Literature on all areas of science and engineering/

Journals
DS

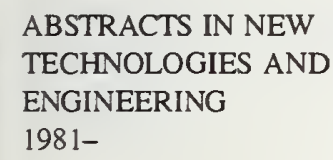

UMI

L, STN
C. STN

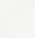


ACCOUNTING \& TAX

DATABASE

1971-
Accounting, taxation, and

financial management

publications from the United

States and other countries/

Journals, newspapers, newsletters, books, pamphlets, theses
UMI

L

ACCOUNTING \& TAX INDEX
ADIS NEWSLETTERS

1982-
Pharmaceutical news and full-text articles/

Newsletters
Adis International, Incorporated

L

INPHARMA; REACTIONS;

PHARMACOECONOMICS

\& OUTCOMES NEWS

\section{ADIS R\&D INSIGHT \\ Current}

The latest on drugs in active development worldwide/
Adis International Ltd. (New Zealand)
DS, L

Journals, industry contacts, reports, newsletters, meetings

\section{ADVERTISE}

Current
Database (in German) of business opportunities for small to medium sized companies, mainly European/
Deutscher Sparkassenverlag GmbH (Germany)
DS

Advertisements

\section{ADVERTISER \& AGENCY RED} BOOKS: ADVERTISERS

Current
Business profiles and corporate linkages for over 29,000 top

U.S. and international companies/

Questionnaires, press releases, telephone research

National Register Publishing

L

Business profiles, corporate linkages and account information for the world's top advertising agencies and their branches/

Questionnaires, press releases, telephone research
ADVERTISER \& AGENCY RED BOOKS: AGENCIES

Current
Worldwide literature related to aerospace information/

\section{2-}

Journals, proceedings, books, theses, reports
American Institute of Aeronautics

L and Astronautics (AIAA); National Aeronautics and Space Administration. (NASA); Aeroplus Access

INTERNATIONAL AEROSPACE ABSTRACTS; SCIENTIFIC AND TECHNICAL AEROSPACE REPORTS 


\section{AERZTE ZEITUNG} 1984
Full text of current information

(in German) on medical trends and management of health services and the pharmaceutical industry/

Newspapers, journals, press releases
Aerzte Zeitung Verlagsgesellschaft mbH (Germany)
DS

AERZTE ZEITUNG

News on political, economic and social developments in Africa/
Comtex Scientific Corporation

L

\section{AFRICA NEWS}

July 1996-

News

Information on services provided

to older persons and services

rendered by them/

Journals, books, reports,

proceedings, theses
American Association of

Retired Persons (AARP)

L

1978-

Full text articles relating to

international news/
Agence France-Presse

DS, $\mathrm{L}$

\section{ENGLISH WIRE}

June 1991-

News items

Full text articles (in French) relating to international news/

Agence France-Presse

DS, L

AGENCE FRANCE-PRESSE

INTERNATIONAL FRENCH WIRE

Sept. 1991-

News items

AGRICOLA (AGRICULTURAL ON-LINE ACCESS)

1970
Worldwide literature in agriculture and related areas/

Journals, monographs, pamphlets, reports, proceedings, translations
U.S. National Agricultural Library; National Technical Information Service

BIBLIOGRAPHY OF AGRICULTURE

\section{AGRIS INTERNATIONAL} 1975-
Worldwide literature on agriculture with emphasis on the United States/

Journals, books, reports, proceedings
U.S. National Agricultural Library; National Technical Information Service

AGRINDEX
FI, L

L 
AIDS/CANCER

1991-
Worldwide scientific literature

in cancer and AIDS research/

Journals
Cambridge Scientific Abstracts

FI
VIROLOGY \& AIDS ABSTRACTS; ONCOGENES \& GROWTH FACTORS ABSTRACTS; IMMUNOLOGY ABSTRACTS

\section{AIDSLINE \\ 1980-}

Literature on AIDS focusing on the biomedical, epidemiological, social, and behavioral areas/
National Library of Medicine

DS, L, STN

Journals

\section{ALLIED AND ALTERNATIVE MEDICINE 1985-}

Literature covering the alternatives to conventional clinical medicine/

Journals, newspapers, books

The British Library (U.K.)

DS, L

The Aluminum Association,

STN composition limits, mechanical and physical properties and Incorporated minimum tensile properties of commercial wrought aluminum alloys/

Property data

Compilation of results of individual plane strain fracture toughness and associated unevaluated notch-tensile test results for aluminum alloys/
The Aluminum Association, Incorporated; National Institute of Standards and Technology (NIST)

Report

World's literature on aluminum from ore processing (not mining) through end uses/

Journals, reports, proceedings, dissertations
Materials Information; Cambridge

L Scientific Abstracts

ALUMINUM INDUSTRY ABSTRACTS

\section{ALUMINUM INDUSTRY ABSTRACTS 1968- TOUGHNESS DATABASE 1968-1989}

Comprehensive literature on U.S. and Canadian history and culture; current affairs and area studies/

Journals, monographs, dissertations
ABC-CLIO, Incorporated

\section{4}


AMERICAN BANKER

1981-
Complete text of articles in the daily financial services newspaper, AMERICAN BANKER/

Newspaper

Contains the most recent news stories and analytic commentary appearing in AMERICAN BANKER/

Newspaper

Directory file providing address, financial and marketing information on U.S. single and multiestablishment companies/

U.S. Bureau of the Census statistics, reports, journals
American Banker-Bond Buyer

DS, L
AMERICAN BANKER NEWS

Current

AMERICAN BUSINESS

DIRECTORY

Current
Information on public, academic, special, and government libraries/

Directory information
R. R. Bowker

L

\section{DIRECTORY}

Current
American Business Information,

L, NVL
L

\section{AMERICAN BANKER}

\section{AMERICAN LIBRARY} DIRECTORY

\begin{abstract}
AMERICAN MEDICAL ASSOCIATION JOURNALS

1982-
\end{abstract}

Full text articles from eleven medical journals/
The American Medical Association

L

Journals $\quad$ Various full text journals

$\begin{array}{lll}\begin{array}{l}\text { ANALYTICAL ABSTRACTS } \\ 1980-\end{array} & \begin{array}{l}\text { Comprehensive literature on } \\ \text { analytical chemistry/ }\end{array} & \begin{array}{l}\text { Royal Society of Chemistry } \\ \text { (U.K.) }\end{array} \\ \begin{array}{l}\text { Journals, books, proceedings, } \\ \text { reports, standards }\end{array} & \text { ANALYTICAL ABSTRACTS }\end{array}$

\section{AP NEWS}

July 1984
Full text of the national, international and business news from the Associated Press/
The Associated Press

L

News

\footnotetext{
*Available also in CD-ROM format from 1980
} 
API ENCOMPASS: NEWS 1975-
International coverage of the literature of petroleum and energy-related news items/

Journals
American Petroleum Institute

L
PETROLEUM/ENERGY BUSINESS NEWS INDEX

\section{APILIT**}

1964
Worldwide coverage of nonpatent literature pertaining to the petroleum and petrochemical industry/

Journals, reports, API publications, conference papers
American Petroleum Institute

L, STN
API LITERATURE

ABSTRACTS
APIPAT**

1964
Petroleum and petrochemical patents/

Patents
American Petroleum Institute

L, STN
Online catalogue of the British Architectural Library covering all aspects of architecture/

Journals, books, reports, proceedings
Royal Institute of British Architects (U.K.)

ARCHITECTURAL PERIODICALS INDEX; ARCHITECTURAL BOOKS CATALOGUE
ART LITERATURE INTERNATIONAL 1973-1989
International literature on the history of art

Journals, books, essays, proceedings, exhibition catalogs, museum publications
RILA, The International

L Repertory of the Literature of Art

RILA
L

\section{8-}

International literature of modern art and design from 1800 to the present/

Journals, dissertations, exhibition catalogues, books
ABC-CLIO, Incorporated

L

ARTBIBLIOGRAPHIES MODERN

OCLC, Incorporated

FI
Index of articles from nearly 12,500 journals/

Journals

\section{ARTICLEFIRST \\ 1990 \\ MODERN \\ 1974}

Journals

\footnotetext{
**Limited to 3 hours use per year
} 
ARTS AND HUMANITIES

SEARCH

1980
Worldwide information on the major areas of the arts and humanities/

Journals
Institute for Scientific Information

DS, L

\section{ARTS AND HUMANITIES} CITATION INDEX

\section{ASFA (AQUATIC SCIENCES AND FISHERIES ABSTRACTS)} 1978-
International comprehensive literature on the life sciences of seas, inland waters, marine and fresh water/

Journals, books, proceedings, reports
Cambridge Scientific Abstracts L, STN

\section{ASI (AMERICAN STATISTICS} INDEX)

1974
Statistical publications of the Federal government with emphasis on environmental, economic, and social aspects/

Journals, reports, statistics
Congressional Information

Service, Incorporated
L
AQUATIC SCIENCES AND FISHERIES ABSTRACTS

\section{ASIA INTELLIGENCE WIRE} 1995-
News and business information covering the Asia-Pacific region/
Financial Times Information (U.K.)
L

\section{AMERICAN STATISTICS} INDEX

Newswires, newspapers, journals

\section{ASIA-PACIFIC}

1985-
Business, economics and new industries of the Pacific RIM nations/

Newspapers, journals, newsletters, proceedings, press releases, monographs
Aristarchus Knowledge

Industries, Incorporated
L
Business directories covering companies, products, and industries in the Asia-Pacific region/

Directories
Various newspaper publishers

L

\section{DIRECTORY}

Current
Important business publications originating in the Asia Pacific region/
JOURNALS

May 1994 
ASIA-PACIFIC BUSINESS NEWS

June 1994-
Important business newspapers originating in the Asia Pacific region/
Various newspaper publishers

L

Newspapers

\section{ASIAN BUSINESS INTELLIGENCE REPORTS \\ Current}

Full text of local reports focusing on developing markets, industries and products of Asia
Asian Business Intelligence, Ltd.

L

Reports

\section{ASIAN COMPANY PROFILES} Current
Records for public and private companies from major trading countries in Asial
Asian Company Profiles, Lid.

(Taiwan)
L

Directory information

ASMDATA

Current
Numeric property file that contains material identification and composition, properties and specifications for composites, plastics, ferrous and non-ferrous alloys and metals/

Property data
ASM International

STN
Literature on the applied aspects

of the social sciences/

Journals, newspapers
Bowker-Saur (U.K.)

DS, L
INDEX AND ABSTRACTS

1987-
ASSIA: APPLIED SOCIAL SCIENCES INDEX AND ABSTRACTS

\section{AUTOMOTIVE ENGINEERING}

1974
Worldwide literature (in German) on all aspects of motor vehicle design, construction, and manufacturing/

Journals, grey literature, reports, theses
Dokumentation Kraftfahrwesen eV.

DS
(Germany)

DKF-LITERATURENFORMATIONSDIENST

\section{AUTOMOTIVE INFORMATION} AND NEWS SERVICE 1987-
International coverage of news, information and the application of new technologies for the automotive industry/

Newspapers, journals, press releases
Forecast International

DS 
DATABASE AND DATES COVERED

\section{AWARDS DATABASE}

Current
DESCRIPTION/

PRINCIPAL SOURCES
PRODUCER AND

HARD COPY COUNTERPART
VENDOR AND/OR

DATABASE INQUIRIES
Scientific and technical awards and honors which are conferred by governments, institutions, foundations, associations, and societies worldwide/

Awards
National Institute of Standards and Technology (NIST) Research Library
A, NVL
News from Estonia, Latvia,

Lithuania and Russia/
Baltic News Service

DS
News

BALTIC

BALTIC NEWS SERVICE
Information on organizations which comprise the financial services industry and on the products and services they offer/

Journals, newspapers, newsletters, case histories
UMI L
1982-
International political and

economic news/

BBC Monitoring (U.K.)

DS

Sept. 1993-

\section{Reports}

\section{SUMMARY OF WORLD BROADCASTS}

BCC MARKET RESEARCH 1990
Market research reports in the areas of plastics, medicine, materials, packaging, ceramics, optics, food, electronics, chemicals and waste treatment research/

Reports
Business Communications

Company
DS, L
Directory of over 20,000 major export-oriented German industrial companies and their products/

Directory information

Structural and factual database in organic chemistry containing more than 350,000 heterocyclic substances/

Property data
Verlag W. Sachon GmbH \& Company DS (Germany)

BDI-DIE DEUTSCHE INDUSTRIE

Beilstein Institute (Germany)

L, STN

\section{9}

BDI GERMAN INDUSTRY

Current 
DATABASE AND DATES

COVERED

BEVERAGE MARKETING

RESEARCH REPORTS

Current

Reports
DESCRIPTION/

PRINCIPAL SOURCES
PRODUCER AND

HARD COPY COUNTERPART
VENDOR AND/OR

DATABASE INQUIRIES
Complete text of reports that detail all aspects of the beverage industry/
Beverage Marketing Corporation

$\mathbf{L}$
Complete text of the modern day revision of the $1769 \mathrm{Bible} /$

Bible
Thomas Nelson Publishers

$\mathbf{L}$

Die Deutsche Bibliothek

STN

BIBLIODATA

Contains publications (in German) collected by the German Library in Frankfurt/ (Germany)

GERMAN NATIONAL BIBLIOGRAPHY
Books, theses, journals, reports, maps, proceedings
Sterling \& Francine Clark Art

Institute
L
European art from the fourth century to the present/

\section{THE HISTORY OF ART}

1990-

Books, periodicals, reviews, proceedings, catalogs, dissertations

BIOBUSINESS

1984
Information on the business applications of biological and biomedical research/

Journals, proceedings
BIOSIS

DS, L, STN
News items on the business aspects of biotechnology and the commercial applications of the biological sciences/

Newsletters, newspapers, journals
BioCommerce Data, Ltd. (U.K.)

DS, L

\section{AND DIRECTORY}

1981-
Information concerning the

BIOETHICS

1973 ethical and public policy aspects in health care or biomedical research/

Journals, newspapers, monographs, court decisions, bills, laws, audiovisuals
Kennedy Institute of Ethics, DS Library of Medicine

\section{ABSTRACTS IN BIOCOMMERCE}

BIBLIOGRAPHY OF BIOETHICS 
DATABASE AND DATES

COVERED

BIOGRAPHY INDEX

July 1984

DESCRIPTION/

PRINCIPAL SOURCES

Listing of biographical material/

Periodicals, books

Locations of biographical

information found in biographical

directories/

Biographical directories
BIOGRAPHY MASTER INDEX

Current
PRODUCER AND

HARD COPY COUNTERPART

H. W. Wilson Company

FI

VENDOR AND/OR

DATABASE INQUIRIES
Life sciences for the undergraduate and high school student

Journals
BIOGRAPHY INDEX

Gale Research Company

L

\section{BIOLOGY DIGEST}

September 1989-
Worldwide literature of the life

sciences/

Journals, reports, reviews,

symposia, books, bibliographies
BIOSIS

BIOGRAPHY AND GEN-

EALOGY MASTER INDEX
BIOSIS PREVIEWS

1969-
Plexus Publishing, Incorporated

FI
BIOLOGICAL ABSTRACTS;

BIORESEARCH INDEX;

BIOLOGICAL ABSTRACTS/

REPORTS, REVIEWS, MEETINGS
BIOTECHNOLOGY ABSTRACTS 1982-
Technical aspects of biotechnology/

Journals, proceedings, patents

Worldwide biotechnology

Journals
Derwent Information, Ltd. (U.K.)

DS, L, STN
DS, FI, L, STN

\section{BIOTECHNOLOGY CITATION \\ INDEX \\ 1994}

\section{literature/}

Institute for Scientific Information

BIO'TECHNOLOGY ABSTRACTS

\begin{tabular}{|c|c|c|c|}
\hline - & Journals & $\begin{array}{l}\text { BIOTECHNOLOGY CITATION } \\
\text { INDEX }\end{array}$ & \\
\hline \multirow[t]{2}{*}{$\begin{array}{l}\text { BISNES PLUS BELGIAN COMPANIES } \\
\text { Current }\end{array}$} & $\begin{array}{l}\text { Complete financial data for all } \\
\text { companies of commercial } \\
\text { significance in Belgium/ }\end{array}$ & INFOTRADE (Belgium) & DS \\
\hline & Newspapers, Official Gazette & - & \\
\hline \multirow{2}{*}{$\begin{array}{l}\text { BLICK-GERMAN BUSINESS } \\
\text { NEWS DAILY } \\
1994\end{array}$} & $\begin{array}{l}\text { Financial overview of the } \\
\text { German business community/ }\end{array}$ & $\begin{array}{l}\text { Frankfurter Allgemeine Zeitung } \\
\text { GmbH (Germany) }\end{array}$ & DS \\
\hline & Newspapers & - & \\
\hline
\end{tabular}

* Available only in CD-ROM format 
BLLDB (BIBLIOGRAPHY OF LINGUISTIC LITERATURE DATABASE)

1971-
Worldwide literature in genuine linguistics and its neighboring disciplines/
Stadt und Universitaetsbibliothek

STN
(Germany)

Journals, proceedings, books, thesis, nonconventional literature

BNA DAILY NEWS FROM WASHINGTON

1990
Daily comprehensive news coverage of national and international government and private sector activities/

Journals
Complete text of the BOND BUYER, a newspaper concerning the U.S. municipal bond industry/

Newspaper
American Banker-Bond Buyer

L

Nov. 1981-
Reviews of fiction and nonfiction books/
H. W. Wilson Company

FI 1983-

Book reviews

BOOK REVIEW DIGEST

References to reviews of books and periodicals/ 1969-
Books, periodicals

Bibliographic information on print, out of print, and forthcoming book titles/

Books
Gale Research Company

L
BOOKS IN PRINT

Current
BOOKS IN PRINT; FORTHCOMING BOOKS IN PRINT; SCIENTIFIC AND TECHNICAL BOOKS IN PRINT; MEDICAL BOOKS IN PRINT
BOWKER BIOGRAPHICAL DIRECTORY

Current
Collection of biographical directories listing biographies of scientists, artists, and politicians/

Biographical data
R. R. Bowker

L
AMERICAN MEN AND WOMEN OF SCIENCE; WHO'S WHO IN AMERICAN ART; WHO'S WHO IN AMERICAN POLITICS 
DATABASE AND DATES

COVERED
DESCRIPTION/

PRINCIPAL SOURCES
PRODUCER AND

HARD COPY COUNTERPART
BRANDS AND THEIR

COMPANIES

Current edition
Worldwide directory of consumer brand names and their owners or distributors/

Questionnaires, published sources
Gale Research, Incorporated

L

BRANDS AND THEIR

COMPANIES; INTER-

NATIONAL BRANDS

AND THEIR COMPANIES

BRIDGE WORLD MARKET NEWS 1989-
Full text financial news/

Reports, market data, quotes
BRITANNICA ONLINE

1997
Full text encyclopedia/

Encyclopedia

Comprehensive index of books published in the United Kingdom/

Books
Britannica Advanced Publishing, Incorporated

\section{ENCYCLOPEDIA BRITANNICA}

J. Whitaker \& Sons, Ltd.

(U.K.)

L
BRITISH BOOKS IN PRINT

Current
Literature on British education

from preschool to adult and

higher education/

Journals

\section{BRITISH BOOKS IN PRINT}

L

NVL
BRITISH EDUCATION INDEX

$1950-$
University of Leeds (U.K.)

L

BRITISH EDUCATION INDEX;

BRITISH EDUCATION THESIS

INDEX (Microfiche)
BUSINESS \& INDUSTRY

1994
Facts, figures, and key events dealing with public and private companies, industries, markets, and products for all manufacturing and service industries at an international level/

Journals, newspapers, newsletters
Responsive Database Services, Incorporated
DS, FI, L
Information dealing with the processes, methods and strategies of managing a business/
Responsive Database Services, Incorporated
L
PRACTICES 1995-

Journals, books 
BUSINESS DATELINE

1985-
Full text of major news and feature stories from U.S. and

Canadian regional business publications/

Business publications
UMI

FI, L
World wide comments and analysis

from leading professional firms and financial advisors on legislative, regulatory, and business issues/

Unpublished information of professional service companies
Business Monitor (U.K.)

DS

1995-
Worldwide directory of organizations that serve business and industry/

Directory information
BUSINESS ORGANIZATIONS

Current
Gale Research, Incorporated

FI

The McGraw-Hill Companies

L
Complete text of articles from BUSINESS WEEK/

BUSINESS WEEK
Publications Online

BUSINESS WEEK
BUSINESS WIRE

1986-
Full text of news releases issued by corporations and other organizations/

News releases
Business Wire

L
Comprehensive literature in agriculture, biology, leisure, recreation, and tourism/

Journals, monographs, reports, patents, proceedings, bibliographies
CAB International (U.K.)

DS, L, STN

\section{WEALTH AGRICULTURAL} BUREAUX)

1973-

\begin{tabular}{ll}
$\begin{array}{l}\text { BUSINESS WEEK } \\
1985-\end{array}$ & $\begin{array}{l}\text { Complete text of articles from } \\
\text { BUSINESS WEEK/ }\end{array}$ \\
& BUSINESS WEEK \\
\hline $\begin{array}{l}\text { BUSINESS WIRE } \\
1986-\end{array}$ & $\begin{array}{l}\text { Full text of news releases issued } \\
\text { by corporations and other organ- } \\
\text { izations/ }\end{array}$
\end{tabular}

al (U.K.)

COMMONWEALTH AGRI-

CULTURAL BUREAUX, JOINT

PUBLICATIONS; LEISURE, RECREATION, AND TOURISM ABSTRACTS

\section{CAB HEALTH \\ 1973-}

Worldwide research on human health and communicable diseases/

Journals, proceedings, books, reports, reviews
CAB International (U.K.)

DS, $\mathbf{L}$ 
CABLE, SATELLITE \& TV NEWS 1995-
Information on cable systems operations, broadcasting, satellite trading, equipment manufacture, etc.

Magazines, newsletters
21 st Century Publishing (U.K.)

DS
Various magazine and newsletter publications

\section{CAMBRIDGE SCIENTIFIC ABSTRACTS \\ Coverage varies}

Literature in the areas of the environment, medicine, biology, aquatics, materials science, and technology/

Journals, proceedings, monographs
Cambridge Scientific Abstracts

NVL

Various abstract publications

Cambridge Scientific Abstracts

L, STN*

Literature of the life sciences/ ABSTRACTS LIFE SCIENCE 1978-
Journals, books, proceedings

Full text of press releases prepared by companies, government, and financial institutions/

CANADA NEWSWIRE

Current

\section{Press releases}

Canadian company, product, and industry information

Newspapers, periodicals
Micromedia, Ltd. (Canada)

$\mathrm{L}$

\section{CURRENT AFFAIRS FULLTEXT}

1982-

\section{Various abstract sources}

L

Canada Newswire, Ltd.

(Canada)

(1)

CANADIAN BUSINESS INDEX; CANADIAN NEWS INDEX

\section{CANADIAN NEWSPAPERS}

1990

\section{Complete text of six Canadian} newspapers/

Newspapers
(Canada)

CALGARY HERALD; FINANCIAL POST; THE GAZETTE; THE OTTAWA CITIZEN; THE TORONTO STAR; THE VANCOUVER SUN

*Available also in CD-ROM format from 1986-1994 


\section{CANCERLINE (CANCER} LITERATURE)

1963-
Articles related to all aspects of cancer/

Journals, reviews, proceedings, government reports
National Cancer Institute;

National Library of Medicine

CANCER THERAPY ABSTRACTS; CARCINOGENESIS ABSTRACTS

\section{CANCORP CANADIAN CORPORATIONS}

Current
Directory, financial, and textual information on more than 6000 public and private Canadian corporations/

Reports, financial statements
Micromedia, Ltd (Canada)

DS, L
Complete coverage of over 1300

key chemistry and chemical-

related journals/

Journals
Chemical Abstracts Service

STN
1967-
Literature on organic chemical reactions/

Journals
Chemical Abstracts Service

STN
1985-
International scientific and technical literature on chemical engineering and biotechnology/ ING AND BIOTECHNOLOGY ABSTRACTS) 1975-
DECHEMA Deutsche STN Gesellschaft für Chemisches Apparatewesen, Chemische Technik und Biotechnologie e.V. (Germany)

Journals, books, reports, theses

CELEX (COMPUTERIZED DOCUMENTATION SYSTEM ON EUROPEAN COMMUNITY LAW) 1951-
Full text and/or references for all European community legislation/
Commission of the European

Communities (Belgium)
DS, L, STN

Treaties, journals, reports, debates

Full text of CHEMICAL AND ENGINEERING NEWS/
American Chemical Society

STN
ENGINEERING NEWS ONLINE) 1991-
Journal
CHEMICAL AND ENGINEERING NEWS 
CERAMIC ABSTRACTS

1976-
Literature on all aspects of ceramics/

Journals, proceedings, patents, reports, books
Cambridge Scientific Abstracts

L, STN

CERAMIC ABSTRACTS

Physical/chemical data, use, hazard, and key reference data on the world's more important chemical substances/

Property data, journals List of chemicals available from

suppliers worldwide/

Chem Sources International

DS
Chapman \& Hall, Ltd. (U.K.)

$\mathrm{L}$
Various print publications
Current
DIRECTORY

Current
CHEM SOURCES INTERNATIONAL

Chem Sources International

DS

\section{DIRECTORY}

Current
Chemicals

Listing of products, names, addresses, telephone and fax numbers of chemical suppliers

worldwide/
Directory information

\section{CHEMCATS}

Current
Catalog file containing information

about commercially available

chemicals and their worldwide

suppliers/

Catalogs

\section{CHEM SOURCES INTERNATIONAL}

Chemical Abstracts Service

STN

\section{CHEMICAL ABSTRACTS \\ 1967-}

Worldwide literature in chemistry and chemical engineering/

Journals, books, reviews, patents, reports, proceedings, dissertations
Chemical Abstracts Service

DS, L, STN*

\section{CHEMICAL BUSINESS \\ NEWSBASE}

October 1984
Covers trends and current affairs in the chemical industry and end-markets/

Journals
Royal Society of Chemistry (U.K.)
DS, L, STN 


\section{CHEMICAL ECONOMICS} HANDBOOK

1955-
Full text chemical supply and demand data/

Chemical data
SRI International

L
CHEMICAL ECONOMICS HANDBOOK
CHEMICAL ENGINEERING AND BIOTECHNOLOGY ABSTRACTS 1970
Theoretical and practical material in all aspects of chemical engineering/
Royal Society of Chemistry

(U.K.)
DS, L

Journals

CHEMICAL SAFETY

NEWSBASE

1981-
Health and safety effects of hazardous chemicals encountered by employees in industry and laboratories/

Journals, books, proceedings
Royal Society of Chemistry

(U.K.)
DS, L, STN

Organic and organometallic

FIZ CHEMIE GmbH (Germany)

STN

1991reactions/

CHEMINFORM

Journals

Chemical Abstracts Service

STN

Listing of chemical substances on the EPA TSCA inventory or subject to regulation under the TSCA/

TSCA chemistry data, FEDERAL

REGISTER data, TSCATS database
Chemical names, formulas, synonyms, registry numbers/

Chemical Abstracts Service

L

\section{NAME DICTIONARY)}

1967

Chemical substance data

\section{CHEMPLANT PLUS}

1980
Information on chemical

manufacturing plants/

Reports, press releases
Reed Information Services

(U.K.)
DS, L 
CHEMREACT

1975-1988
Reaction-based chemical reaction database containing about 300,000 organic reactions selected from published reactions in the chemical literature/

Journals
InfoChem GmbH (Germany)

STN

\section{CHEMSAFE}

Current
Flammable substances safety data/
Bundesanstalt für Materialforschung und-pruefung (BAM);

DECHEMA; Physikalisch-Technische

Bundesanstalt (PTB) (Germany)

Journals, laws, regulations, datasheets

\section{CHEMSEARCH}

1957-
Identifying information for over 12 million chemical substances/
CHEMICAL ABSTRACTS SERVICE
L

Chemical substance data

Information on chemical trade and production statistics/
Reed Information Services

(U.K.)
L

Statistical publications, journals, reports, tapes

\section{CHEMTOX ONLINE}

Current
Environmental, health and safety data for chemical substances/

MSDS, government agency data, books, reports, journals

Resource Consultants, Incorporated

L

Bibliographic information on all patent applications published under the new Chinese patent law/
Patents
European Patent Office (Austria)
L
April 1985-

\section{PATENT ABSTRACTS OF CHINA}

\section{CIN (CHEMICAL INDUSTRY NOTES)}

1974
Business-oriented literature in the chemical industry/
Chemical Abstracts Service

DS, L, STN 
CIVIL ENGINEERING DATABASE

1975-
Literature on all aspects of civil engineering/

Books, proceedings, journals, reports, standards, news
American Society of Civil

STN

\section{Engineers}

Full text of American Chemical American Chemical Society

Society journals/

Journals

Full text of papers included in JOURNAL OF THE ASSOCIATION OF OFFICIAL ANALYTICAL CHEMISTS/

Journal
JOURNAL OF THE ASSOCIATION OF OFFICIAL ANALYTICAL CHEMISTS

\section{CJELSEVIER 1990-1997}

Full text of four chemical journals published by Elsevier/

Journals
Elsevier Science B.V.

STN
STN

Various ACS Journals
STN
ANALYTICA CHIMICA ACTA; APPLIED CATALYSIS; CARBOHYDRATE RESEARCH; JOURNAL OF ORGANOMETALLIC CHEMISTRY

\section{CJRSC}

1987-1997
Full text of the chemical journals of the Royal Society of Chemistry/

Journals

Full text of papers in ANGEWANDTE CHEMIE/

Journal

Full text information from polymer journals/

Journals
Royal Society of Chemistry

STN (U.K.)

Various Royal Society journals

VCH Verlagsgesellschaft

STN

(Germany)

ANGEWANDTE CHEMIE

CJWILEY

1987-1997
John Wiley and Sons, Incorporated

STN 


\section{CLAIMS/CITATION}

1947-
A listing of U.S. patents and cited references/

Patents
Search Check, Incorporated;

IFI/Plenum Data Corporation
L
CLAIMS/COMPOUND REGISTRY

Current
Dictionary of specific chemical compounds of interest for

searching in the claims/uniterm

patent files/

Compound data
IFI/Plenum Data Corporation

L
COMPOUND TERM LIST

NAME/NUMBER ORDER;

COMPOUND TERM LIST

MOLECULAR FORMULA

ORDER

\begin{tabular}{|c|c|c|c|}
\hline $\begin{array}{l}\text { CLAIMS/REASSIGNMENT \& } \\
\text { REEXAMINATION } \\
\text { 1980- }\end{array}$ & Current status of U.S. patents/ & IFI/Plenum Data Corporation & L, STN \\
\hline & Patents & - & \\
\hline $\begin{array}{l}\text { CLAIMS/REFERENCE } \\
\text { Current }\end{array}$ & $\begin{array}{l}\text { Dictionary index to the U.S. } \\
\text { Patent Office's classification } \\
\text { codes/ }\end{array}$ & IFI/Plenum Data Corporation & L, STN \\
\hline & Patents & - & \\
\hline
\end{tabular}

\section{CLAIMS/U.S. PATENTS}

1950-
A series of files listing U.S. patents issued by the U.S. Patent and Trademark Office/

Patents
IFI/Plenum Data Corporation

L, STN

U.S. PATENT OFFICIAL

GAZETTE

\section{CLAIMS/UNITERM}

1950

Chemical and chemicallyrelated patents plus subject indexing/

Patents
IFI/Plenum Data Corporation

L, STN
Information about the computer, communications and electronics industries/

Newspapers, magazines
CMP Media, Incorporated

L

\section{8-}


COIN-NUMERIC

1983-
Balance sheets, profit/loss accounts and rations of Germany's biggest industrial trading and service companies/

Annual reports
Verband der Vereine Creditreform e.V. (Germany)
DS

U.S. Dept. of Commerce

L
COMMERCE BUSINESS DAILY

October 1982-
Announcements of products and services wanted or offered by the U.S. government
Contract awards or announcements

Directory information and news coverage for 100,000 private and public businesses/

\section{COMMERCE BUSINESS DAILY}

Information Access Company
COMPANY INTELLIGENCE

Current

Journals, questionnaires,

interviews, directories

Worldwide engineering and technological literature/
Engineering Information, Incorporated
DS, L*, NVL, STN

\section{INDEX)}

1970-
Journals, transactions, proceedings, government reports

ENGINEERING INDEX

Literature of theoretical and applied computer science/

INFORMATION SYSTEMS

ABSTRACTS)

1981-
Books, proceedings, reports, journals
COMPUTER AND INFORMATION SYSTEMS ABSTRACTS JOURNAL
COMPUSCIENCE

1972
Literature of computer science and technology/

Journals
FIZ Karlsruhe (Germany)

STN
Technical and consumer information with some full text on computers, telecommunications and electronics/

Journals, newsletters, proceedings
Information Access Company

DS, L

THE CON-

DS, L 
COMPUTER NEWS FULLTEXT 1989-
Full text of COMPUTERWORLD and NETWORK WORLD/

Journals
IDG Communications

L

COMPUTER WORLD; NETWORK WORLD
COMPUTER SELECT

Most recent 12 months

\section{Computer news and develop-} ments/

Journals
Information Access Company

NVL**

\begin{tabular}{lll}
\hline $\begin{array}{l}\text { CONF } \\
1976-\end{array}$ & $\begin{array}{l}\text { Information on past, current and } \\
\text { future conferences on energy, } \\
\text { physics, mathematics, computer } \\
\text { sciences and engineering/ }\end{array}$ & FIZ Karlsruhe (Germany) \\
& Conferences & \\
$\begin{array}{l}\text { CONFERENCE PAPERS INDEX } \\
\text { (CPI) }\end{array}$ & $\begin{array}{l}\text { Scientific and technical papers } \\
\text { presented at conferences/ }\end{array}$ & Cambridge Scientific Abstracts
\end{tabular}

1973-

Proceedings

Comprehensive legislative information from CONGRESSIONAL RECORD/

Bills, amendments, speeches, floor actions

CONGRESSIONAL RECORD

1981-
An index of articles providing consumer information

Periodicals

\section{CONFERENCE PAPERS INDEX}

M
CONGRESSIONAL RECORD

\section{CONSUMERS INDEX}

\section{6-}

Complete text of major articles from CONSUMER REPORTS/

Journal

Table of contents of nearly 12,500 journals/

Journals
Consumers Union

$\mathrm{L}$

\section{CONSUMER REPORTS}

OCLC, Incorporated

FI

1990

**Available in CD-ROM format 
COPPERDATA

Current
Numeric file of physical and mechanical properties of copper

and copper alloys/

Property data

Directory information on businesses and corporate linkages to parent organizations/

Directory information
Copper Development Association, Incorporated

STN

CDA STANDARDS HANDBOOK
CORPORATE AFFILIATIONS

Current
Facts and figures about the retail trade in Europe/ U.K. AND EUROPEAN RETAILING 1990

\section{Reports}

\section{CORPTECH}

Current
Profiles on over 30,000 U.S. entities that manufacture or develop high technology products/

Directory information
National Register Publishing

Company
L

Janet Matthews Information Services

DS (U.K.) 
CREDITREFORM GERMANY

Current
Comprehensive source of information on German companies/

Questionnaires, data from official sources
Verband der Vereine Creditreform DS

e.V. (Germany)

$-$

Profiles of companies registered in Switzerland/

Schweizerischer Verband

DS

\section{COMPANIES}

CREDITREFORM SWISS

Current
Directory information
UMI

L

\section{CRIMINAL JUSTICE PERIODICAL INDEX 1975-}

\section{Covers areas of criminology,}

criminal law, security systems, corrections and police/

Journals
CRIMINAL JUSTICE PERIODICAL INDEX

\section{CRIS/USDA}

Current
Listing of current research projects in agriculture and related subjects/

Research projects

\section{U.S. Department of Agriculture}

L

\section{CSCHEM}

Current
Catalog file containing information about chemical products and their suppliers/

Catalog information
Directories Publishing Company, Incorporated

CHEM SOURCES-USA

\section{CSCORP}

Current
Directory information about companies that supply chemicals and chemical products/

Directory information
Directories Publishing Company, Incorporated

STN
Literature on the scientific, technical and technocommercial aspects of biotechnology/
Royal Society of Chemistry

(U.K.)
STN

\section{ABSTRACTS} 1983-

\section{CHEM SOURCES-USA}


CURRENT CONTENTS SEARCH

Most current 6 months
Table of contents of journals in the areas of life sciences, physical sciences, engineering, agriculture, and biology/

Journals
Institute for Scientific Information

DS, L
Current pharmaceutical patents/

CURRENT PATENTS FAST-ALERT 1989-
Current Patents, Ltd. (U.K.)

DS

Patents

\section{D\&B-ASIA-PACIFIC DUN'S MARKET IDENTIFIERS Current}

Directory listings on businesses in forty countries within Asia and the Pacific RIM, including Australia and New Zealand/

Credit investigations, government registrations
Dun \& Bradstreet Information

DS, $\mathrm{L}$

\section{Services}

Financial data for 350,000

Canadian companies/
Dun \& Bradstreet Information

Services
DS, L
MARKET IDENTIFIERS

Current

\section{Business data}

D\&B-DUN'S FINANCIAL RECORDS PLUS

Current
Financial information on public and private companies/
Dun \& Bradstreet Information Services
L
Financial and marketing data
D\&B-DUN'S ELECTRONIC BUSINESS DIRECTORY

Current
Directory information for nearly 8.5 million businesses and professionals throughout the United States/
Dun \& Bradstreet Information Services
L
Data from interviews

\section{D\&B-DUN'S MARKET \\ IDENTIFIERS \\ Current}

Directory file containing address, financial and marketing information on U.S. business establishments/

Financial and marketing data
Dun \& Bradstreet Information
Services
DS, $\mathbf{L}$ 
D\&B-EUROPEAN DUN'S MARKET IDENTIFIERS

Current
Directory listings for over $1,500,000$ businesses in 29

European countries/

Interviews
Dun \& Bradstreet Information Services
L
Financial information on private and public companies in Europe/

Questionnaires, interviews, reports, financial statements
Dun \& Bradstreet Information Services
DS, L

\section{RECORDS}

Current
Worldwide links from companies to corporate families/
Dun \& Bradstreet Information Services
L

\section{LINKAGES}

Current
Interviews, government sources, mailings

\section{D\&B-INTERNATIONAL DUN'S MARKET IDENTIFIERS \\ Current}

Directory listing with sales volume and marketing data for leading companies throughout

the world/

Directory information, marketing

data
Dun \& Bradstreet Information Services
$\mathbf{L}$
Marketing information on more than 90,000 companies in

Switzerland/

Directory information
Dun \& Bradstreet (Switzerland)

DS

\section{MARKETING FILE}

1985-
Full financial accounts for all limited liability companies in DenmarkJ

Company information, financial accounts
Koebmandsstandens Oplysnings-

DS

\section{FINANCIAL DATA}

Current
Bureau A/S (Denmark)

(1)


DATAPRO REPORTS AND ANALYSIS Current
Full text market research reports on computers, communications, information systems, and workgroup computing/
Datapro Information Services Group
L

Reports

DELPHES EUROPEAN BUSINESS 1980-
French database on international markets, products, industries, and companies/

Journals, newspapers, books, reports, market studies
Paris Chamber of Commerce and Industry (France)
DS, L

German aerospace literature/

FIZ Karlsruhe (Germany)

STN

1985-1997

Books, journals, patents, reports, conferences, nonconventional literature

\section{DERWENT CROP PROTECTION}

FILE

1985 -
Worldwide information on all issues concerning pesticides and other agrochemicals/

Journals, proceedings, reports
Derwent Information, Ltd.

(U.K.)
DS, STN
DERWENT DRUG FILE

1964
Worldwide pharmaceutical literature/

Journals, proceedings
Derwent Information, Ltd.

(U.K.)
DS, L, STN
Structure-searchable chemical reactions database providing key references to novel synthetic methods from the worldwide patent and scientific literature/

Journals, patents
Derwent Information, Ltd. (U.K.)

STN SYNTHETIC METHODS FILE 1975-1994

Citation data from published patent applications from 16 countries/

\section{DERWENT JOURNAL OF SYNTHETIC METHODS}

\section{DERWENT PATENTS CITATION} INDEX

1973-
Derwent Information, Ltd.

L
(U.K.)

(


DETHERM (DECHEMA THERMOPHYSICAL PROPERTY DATA BANK)

1819-
Pure compound and mixture thermophysical data on some I2,000 organic and inorganic substances/

Journals
FIZ CHEMIE; DECHEMA

(Germany)
STN

\begin{tabular}{lll}
$\begin{array}{l}\text { DGENE (DERWENT GENESEQ) } \\
\text { I981- }\end{array}$ & $\begin{array}{l}\text { Nucleic acids and amino acids } \\
\text { that have been extracted from } \\
\text { the original patents from } 40 \\
\text { issuing authorities/ }\end{array}$ & $\begin{array}{l}\text { Derwent Information, Ltd. } \\
\text { (U.K.) }\end{array}$ \\
\hline $\begin{array}{l}\text { Patents } \\
\text { DHMT }\end{array}$ & $\begin{array}{l}\text { Medical toxicology and environ- } \\
\text { mental health }\end{array}$ & Dept. of Health (U.K.) \\
& $\begin{array}{l}\text { Journals, proceedings, reports, } \\
\text { books, pamphlets }\end{array}$ & \\
\hline
\end{tabular}

STN that have been extracted from the original patents from 40 (U.K.)

(n)

\begin{tabular}{|c|c|c|c|}
\hline $\begin{array}{l}\text { DHSS-DATA } \\
\text { 1983- }\end{array}$ & $\begin{array}{l}\text { Online database of the Depart- } \\
\text { ment of Social Security Library } \\
\text { in London' } \\
\text { Journals, books, reports, pamphlets }\end{array}$ & $\begin{array}{l}\text { Department of Health Library } \\
\text { and Information Services (U.K.) }\end{array}$ & DS \\
\hline $\begin{array}{l}\text { DIALOG HEADLINES } \\
\text { Current }\end{array}$ & $\begin{array}{l}\text { Latest information on the top } \\
\text { news topics of the day/ } \\
\text { Wire services, newspapers }\end{array}$ & $\begin{array}{c}\text { Selected news suppliers } \\
\text { - }\end{array}$ & $\mathrm{L}$ \\
\hline $\begin{array}{l}\text { DIALOG/MONEYCENTER } \\
\text { Current }\end{array}$ & $\begin{array}{l}\text { Menu-driven price and rate } \\
\text { quotation and news service } \\
\text { covering major U.S. and } \\
\text { international cash futures and } \\
\text { options markets/ } \\
\text { Exchanges, banks, mortgage } \\
\text { bankers, reporters }\end{array}$ & $\begin{array}{c}\text { The Dialog Corporation } \\
\\
-\end{array}$ & $\mathrm{L}$ \\
\hline $\begin{array}{l}\text { DIALOG QUOTES AND TRADING } \\
\text { Current }\end{array}$ & $\begin{array}{l}\text { Gateway service which provides } \\
\text { stock and option quotes from the } \\
\text { New York and American Stock } \\
\text { Exchange, NASDAQ and the } \\
\text { four major option exchanges/ } \\
\text { Stock exchange quotes }\end{array}$ & Trade * Plus & $\mathrm{L}$ \\
\hline
\end{tabular}


DIALOG SOURCEONE:

\section{ENGINEERING}

1991-
World's major engineering and technological literature plus document delivery of same/

Journals, proceedings, reports
Engineering Information,

L Incorporated
The Royal Society of Chemistry

L
(U.K.)
AND THEIR EFFECTS (DOSE)

Current de to impact of chemicals organisms and the environment/

Toxicity, regulatory information, environmental fate information
DIOGENES

1976-
Full text of published and unpublished regulatory information concerning the health care industry/

Regulations, newsletters
FOI Services, Incorporated

DS, L
Regulation of human drugs and medical devices/ UPDATES

Varies
DIOGENES

DS

Regulation, newsletters

Textual information and numeric physical property data for American Institute of Chemical STN* DIPPR (DESIGN INSTITUTE FOR PHYSICAL PROPERTY DATA) 1982Engineers commercially important chemical substances/

Chemical data

Comprehensive guide to Polish companies and government organizations/
Centrum Informacji Profesjonalne (Poland)
DS COMPANIES

Current

Directory information

Worldwide coverage of conference

proceedings/

Conference proceedings
InterDok Corporation

DS

\section{PROCEEDINGS} 1990
DIRECTORY OF PUBLISHED PROCEEDINGS

*PC version also available 
DATABASE AND DATES

COVERED

DISCLOSURE

Current
DESCRIPTION/

PRINCIPAL SOURCES
PRODUCER AND

HARD COPY COUNTERPART
VENDOR AND/OR

DATABASE INQUIRIES
Information extracted from reports filed with the SEC by

10,000 publicly-held companies/

Reports
Disclosure, Incorporated

DS, L
Detailed and summary ownership information for about 5000 public companies/

Data

DISCLOSURE/SPECTRUM
OWNERSHIP
Current

DISCLOSUR

Current
Disclosure, Incorporated

L
Listing of doctoral and master dissertations granted by U.S. universities and other countries/

Dissertations
University Microfilms International

DS, FI, L, STN
DISSERTAT
ONLINE
$1861-$
DISSERTATION ABSTRACTS

INTERNATIONAL; AMERICAN

DOCTORAL DISSERTATIONS
Directory of German and European certification and testing bodies/

Directory information

Information on vehicle tests taken from ten international journals/

Journals

\begin{abstract}
DITR-ZERTIFIZIERUNGSSTELLEN 1995-
\end{abstract}

DITR (Germany)

DS

\section{DKF VEHICLE TEST REPORTS}

1979-
Dokumentation Kraftfahrwesen e.V. (Germany)
DS
Company details on Norwegian public and privately-owned companies/

Industry catalogs, telephone interviews

\section{DM HUSET NORWEGIAN COMPANIES \\ Current}

Comprehensive listing of nonclassified U.S. government prime contracts of $\$ 25,000$ or more/
DM Huset (Norway)

DS

\section{DMS/FI CONTRACT AWARDS}

FY1981-
Forecast International/DMS

L

\section{Contracts}




DMS/FI MARKET INTELLIGENCE
REPORTS
1959-

\section{9-}

Worldwide comprehensive full text database covering activities within the aerospace/defense market/

Journals, reports, news releases
Forecast International/DMS

L
Full text of business and financial news/

Newspapers, journals
Dow Jones and Company,

DO 1979-(varies)
Incorporated

WALL STREET JOURNAL; WASHINGTON POST; BARRON'S; MCGRAW-HILL BUSINESS LIBRARY; etc.
DROLS (DEFENSE RDT+E ON-LINE SYSTEM)

1953-
Multidisciplinary coverage of classified and unclassified technical reports generated by U.S. government sponsored research/

Reports
Defense Technical Information Center (DTIC)

TECHNICAL ABSTRACT BULLETIN

\section{DRTE (DRT EC AND EASTERN EUROPE BUSINESS DATABASE) Current}

Comprehensive full text file of business and industry information in the European Community (EC)/
DRT Europe Services (Belgium)

DS

Newspapers, journals, unpublished data sources, EC official publications

DRUG DATA REPORT 1988-
Information on more than 65,000 bioactive compounds/

Journals, patents, symposia, company communications
Prous Science Publishers (Spain)

DS, L

D 
DRUG NEWS \& PERSPECTIVES

1992-
Most current news on drug developments and use/

DRUG NEWS \&

PERSPECTIVES
Prous Science Publishers

(Spain)

DRUG NEWS \&

PERSPECTIVES
Comprehensive drug monographs providing product information

on new compounds/

Monographs
Prous Science Publishers (Spain)

L
Directory and sales information for companies in Austria/

Interviews, questionnaires
Directory and sales information for Belgian companies/

Interviews, questionnaires
Dun \& Bradstreet International

DS

Current
Directory and sales information

for Danish companies/

Interviews, questionnaires
DRUGS OF THE FUTURE
DS, L
1990 -
DUN \& BRADSTREET AUSTRIA Current

\section{DRUGS OF THE FUTURE}

DUN \& BRADSTREET DENMARK

Current

\author{
Interviews, questionnaires
}

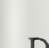

DUN \& BRADSTREET EASTERN

EUROPE

Current

\section{Business information on} companies in Poland, Hungary,

and Czechoslovakia/

Company information, government information
Dun \& Bradstreet Information Services DS

(1)


DATABASE AND DATES COVERED
DESCRIPTION/ PRINCIPAL SOURCES
PRODUCER AND

HARD COPY COUNTERPART
VENDOR AND/OR

DATABASE INQUIRIES
DUN \& BRADSTREET GREECE

Current
Directory and sales information

for Greek companies/

Interviews, questionnaires
Dun \& Bradstreet Information

DS
Directory and sales information

for Irish companies/

Interviews, questionnaires
Dun \& Bradstreet Information

DS

Current
Services
Business information on more then 12,000 Israeli companies/

Interviews, questionnaires
Dun \& Bradstreet Information

DS

Services

DUN'S GUIDE TO ISRAEL
DUN \& BRADSTREET ITALY

Current
Directory and sales information for Italian companies/

Interviews, questionnaires
Dun \& Bradstreet Information Services
DS
Directory and sales information for Japanese companies/

Interviews, questionnaires
Dun \& Bradstreet Information

DS
DUN \&
Current

DUN \& BRADSTREET

LUXEMBOURG

Current
Directory and sales information for companies in Luxembourg/
Dun \& Bradstreet Information

DS
Services
Interviews, questionnaires
DUN \& BRADSTREET MIDDLE EAST, AFRICA, AND LATIN AMERICA

Current
Directory of companies based in the Middle East, Africa, and Latin America/
Dun \& Bradstreet Information Services
DS

Company information, interviews

Directory and sales information for Dutch companies/
Dun \& Bradstreet Information Services

Current

Interviews, questionnaires 
DUN \& BRADSTREET PORTUGAL Current
Directory and sales information for companies in Portuga/

Interviews, questionnaires
Dun \& Bradstreet Information

DS
Directory and sales information for companies in Spain/

Interviews, questionnaires
Dun \& Bradstreet Information

Services
DS

DUN \&
Current
Full financial data for over 1000 Swiss companies/

Dun \& Bradstreet Information Services

DS

\section{COMPANIES FULL FINANCIAL}

DATA

Current
Company-derived data
Directory and sales information for British companies/
Dun \& Bradstreet Information Services
DS
Interviews, questionnaires
Complete text of current day's news from nine Canadian newspapers/

Newspapers

Complete text of current day's news from five U.S. newspapers/
The Dialog Corporation

L
L
CHICAGO TRIBUNE; LOS
ANGELES TIMES; NEW YORK
TIMES; SAN FRANCISCO

TIMES; SAN FRANCISCO

CHRONICLE; WASHINGTON POST

\begin{tabular}{ll}
$\begin{array}{l}\text { EBIS-EMPLOYEE BENEFITS } \\
\text { INFOSOURCE } \\
\text { 1986- }\end{array}$ & $\begin{array}{l}\text { Comprehensive information on } \\
\text { all facets of employee benefit } \\
\text { plans/ }\end{array}$ \\
& $\begin{array}{l}\text { Journals, newspapers, newslette } \\
\text { reports, news releases, proceed }\end{array}$ \\
\hline $\begin{array}{l}\text { EBSCO MAGAZINES } \\
1984-\end{array}$ & $\begin{array}{l}\text { Index with some full text to } \\
\text { business, humanities, general } \\
\text { science, social science, health, } \\
\text { trade, and vocation periodicals/ }\end{array}$ \\
& Periodicals
\end{tabular}

International Foundation of

L
Employee Benefit Plans

\section{\begin{tabular}{l} 
UNITED KINGDOM \\
Current \\
EARLY EDITION-CAN \\
Most recent 24 hours \\
\hline EARLY EDITION-U.S. \\
Most recent 24 hours
\end{tabular} \\ \begin{tabular}{l} 
UNITED KINGDOM \\
EArTent \\
Most recent 24 hours \\
\hline EARLY EDITION-U.S. \\
Most recent 24 hours
\end{tabular} \\ UNITED KINGDOM
Current
EARLY EDITION-CANADA
Most recent 24 hours

EARLY EDITION-U.S.
Most recent 24 hours \\ UNITED KINGDOM
Current
EARLY EDITION-CAN
Most recent 24 hours

EARLY EDITION-U.S.
Most recent 24 hours}


DATABASE AND DATES COVERED

ECONBASE: TIME SERIES AND FORECASTS

1948-
DESCRIPTION/

PRINCIPAL SOURCES
PRODUCER AND

HARD COPY COUNTERPART
VENDOR AND/OR

DATABASE INQUIRIES
Compilation of critical economic data used for researching, monitoring and reporting economic, financial and industry specific trends/

\section{WEFA Group}

L

Statistical data

Worldwide literature on all aspects of economics/

Journals
American Economics Association

FI, L 1969-
INDEX OF ECONOMICS

ARTICLES; JOURNAL OF

ECONOMICS LITERATURE
ECONOVO

1985-
Legal announcements (in

German) of German companies published in the official gazette of the Ministry of Justice/

Company information
Bundesanzeiger Verlagsgesellschaft

DS

\section{BUNDESANZEIGER}

Bundesanzeiger Verlagsgesellschaft

DS

Information (in German) on registration of German companies published in the official gazette mbH (Germany)

1985-

of the Ministry of Justice/

Company information

BUNDESANZEIGER

Documents filed with the

Disclosure, Incorporated

$\mathbf{L}$

1993-

Securities and Exchange

Commission (SEC)/

Reports, filings, prospectuses, statements

\section{EDUCATION INDEX}

June 1983-
Literature in the field of education/
H. W. Wilson Company

FI, L

Periodicals

Full text business information from 59 countries/
The Economist Intelligence Unit

DS, L

\begin{abstract}
1989-
\end{abstract}
Reports, newsletters, business guides, regional overviews, investment profiles 
EIU: BUSINESS NEWSLETTERS 1989-
EIU's international, regional and country business newsletters/
The Economist Intelligence Unit

DS, L

Newsletters

Complete text of EIU reports that provide useful background for operating in 180 countries/

Reports
The Economist Intelligence Unit

DS, L

\section{I989-}

Analysis of the short and medium term economic credit worthiness of over 90 countries/
The Economist Intelligence Unit

DS, L

EIU: COUNTRY RISK AND
FORECASTS
1989-

1989
Reports
Describes developments in over 180 countries and what these changes mean for business/

Original research, EIU publications, World Bank publications
The Economist Intelligence Unit

DS, L 1989-

Worldwide literature on electronic systems, circuits, devices and communications/

Proceedings, reports, journals, patents, theses

Listing of electrical and electronic products manufactured and offered for sale by about 1,950 companies in Germany/
Cambridge Scientific Abstracts

STN

\section{COMMUNICATIONS ABSTRACTS)}

1981-

\section{ELECTRO/ELECTRONICS Current}

EMBASE

1974
Worldwide biomedical literature/

Journals, books, proceedings

\section{ENCYCLOPEDIA OF ASSOCIATIONS \\ Current}

Descriptive information on nonprofit American membership organizations of national scope/

Directory information obtained from questionnaires

\section{ELECTRONICS AND COMMU- NICATIONS ABSTRACTS}

Elsevier Science B.V.

(The Netherlands) LITERATURE INDEX
EXCERPTA MEDICA; DRUG
Verlag W. Sachon, GmbH and

DS
DS, L, STN

Gale Research Incorporated

L, NVL
THE ENCYCLOPEDIA OF ASSOCIATIONS 
ENERGIE

1976-
Literature on energy research

and technology published in

German speaking countries/

Journals, reports, books, patents, proceedings
FIZ Karlsruhe (Germany)

STN
International literature on energy and related fields/

Reports, books, proceedings, patents, journals

National Technical Information

L, STN

\section{ENERGY SCIENCE AND} TECHNOLOGY

1974
Service; U.S. Department of

Energy

ENERGY RESEARCH ABSTRACTS; ENERGY ABSTRACTS FOR POLICY ANALYSIS

\section{ENERGYLINE}

1971-1993
Comprehensive coverage of energy and environment

Journals, reports, monographs, hearings
ENGINEERED MATERIALS

ABSTRACTS (EMA)

1986-
World's literature on polymers, ceramics, and composites/

Journals, proceedings, reports, books, theses, patents

\section{ENGINEERING INDEX see COMPENDEX}

\section{ENVIROLINE}

1975-
Worldwide coverage of literature in environmental studies/

Journals, new releases, reports, patents, films
Index to key aspects of environmental science/

Journals
ENVIRONMENT

1992-
ENVIRONMENTAL BIBLIOGRAPHY

(EPB)

1973-
Literature of general human ecology, atmospheric studies, energy, land, and water resources, health, and nutrition/

Journals
Congressional Information Service, Incorporated

ENERGY INFORMATION ABSTRACTS; ENVIRONMENT ABSTRACTS
Materials Information; Cambridge

L, STN Scientific Abstracts; Institute of Materials

\section{ENGINEERED MATERIALS} ABSTRACTS
Congressional Information Service, DS, L Incorporated

ENVIRONMENT ABSTRACTS
Cambridge Scientific Abstracts

FI
L
Environmental Studies Institute

L 
DATABASE AND DATES COVERED
DESCRIPTION/

PRINCIPAL SOURCES
PRODUCER AND

HARD COPY COUNTERPART
VENDOR AND/OR

DATABASE INQUIRIES
EPD (ELECTRIC POWER DATA

BASE)

1972-
Summaries of ongoing and completed research projects in the electric utility industry/

Research projects
Electric Power Research Institute
L

ERIC (EDUCATIONAL RESOURCES
INFORMATION CENTER)
1966-

Literature in education, social sciences, and educational-related areas/

Journals, research reports, ephemera
U.S. Department of Education; ERIC Research and Processing Facility

RESEARCH IN EDUCATION; CURRENT INDEX TO JOURNALS IN EDUCATION
DS, $\mathbf{L}$

\section{ESPICOM PHARMACEUTICAL \& MEDICAL DEVICE NEWS 1995-}

Worldwide news and developments on companies and markets in the pharmaceutical and medical device industry/

Newsletters
ESPICOM Business Intelligence

DS, L (U.K.)

MEDISTAT NEWS; PCA NEWS; MDCA NEWS

\section{ESPICOM TELECOMMUNICATIONS/ POWER REPORTS \\ Current}

Worldwide profiles of telecommunications operating companies, equipment manufacturers and markets/
ESPICOM Business Intelligence (U.K.)

Reports

Details of public financing programs which are available to support business activities in Europe/

Financing programs
Euro-Select-Datenbank GmbH

(Germany)
DS
Current
Full text of selected Euromoney financial publications/

Journals
Euromoney Publications plc

(U.K.)
DS

Various Euromoney publications

Euromonitor plc (U.K.)

DS

EUROMONITOR JOURNALS 1995-
Full text of Euromonitor's four monthly journals of European and international market research/

Journals

\author{
MARKET RESEARCH EUROPE; \\ MARKET RESEARCH GREAT \\ BRITAIN; MARKET RESEARCH \\ INTERNATIONAL; RETAIL \\ MONITOR INTERNATIONAL
}


EUROMONITOR MARKET

DIRECTION

Current
Marketing information on 57 consumer product sectors in the United Kingdom, France, Italy, Germany, and the United States/

Reports, journals, market analysis, forecasts
Euromonitor plc (U.K.)

DS, L
EUROMONITOR MARKET DIRECTION COUNTRY REPORTS

\section{EUROMONITOR MARKET REPORTS \\ 1990}

Full text of EUROMONITOR MARKET REPORTS containing consumer market analysis and company information/

Report
Euromonitor plc (U.K.)

DS, L
EUROMONITOR MARKET REPORTS

\section{EUROPATFUL}

1996-
Complete text of patent applications and granted patents/

Patents
Wila Verlag (Germany)

STN
European Chemical News (U.K.)

DS

Current news on chemicals and related industries/ Journal

EUROPEAN
April 1984

CHEMICAL NEWS

\section{EUROPEAN PATENTS FULLTEXT} 1978-
Full text of European patent applications and granted patents/

Patents
European Patents Office (Austria)

$\mathbf{L}$
Coverage of European commercial research activities and publicly-

funded and academic research/

Directory information
Bowker-Saur (U.K.)

DS, L DEVELOPMENT DATABASE Current

\section{EUROPEAN RESEARCH \&} DEVELOPMENT DATABASE

\section{EUROPEX}

Current
Directory database on exporting manufacturing companies in 40 European countries/
Unternehmensgruppe STN

\section{Directory information}

\section{EVENTLINE} 1989-
Listing of current and future international conferences, trade fairs, exhibitions, and major sports events/

Primary and secondary sources; Elsevier's publications
Elsevier Science B.V. (The Netherlands)
DS, FI, L, STN 
EXTEL INTERNATIONAL FINANCIAL CARDS

Oct. 1989-
Comprehensive financial, textual and background information on quoted, unquoted and other large international companies/

Reports
Extel Financial, Ltd. (U.K.)

DS, L
News and basic company information on quoted, unquoted and other large international companies/

Company announcements
Extel Financial, Ltd. (U.K.) DS, L

$\begin{array}{lll}\text { EXTEL INTERNATIONAL } & \text { News and basic company } & \text { Extel Financial, Ltd. (U.K.) } \\ \text { NEWS CARDS } & \begin{array}{l}\text { information on quoted, unquoted } \\ \text { and other large international } \\ \text { companies/ }\end{array} & \\ \text { Oct. 1989- } & \text { Company announcements } & -\end{array}$

EXTRAMED

1992-
Biomedical literature of the developing countries/

Journals
Informania Ltd. (U.K.)

L
Worldwide information on the health care industry/

Reports
F-D-C Reports, Incorporated

DS, L
$1987-$
Facts and statistics from various sources/
Pierian Press, Incorporated

FI
1984

Newspapers, periodicals, hearings

\section{FAKT \\ 1989-}

Current statistical information from the German business press/

Newspapers, journals, magazines, reports
Infratest Burke AG (Germany)

DS
FBR ASIAN COMPANY PROFILES Current
Profiles of companies from major trading countries in Asia/

Credit reports
FBR Data Base, Incorporated

L
Full text of the federal acquisition regulations and its supplements/
U.S. Government Printing Office

L

FEDERAL ACQUISITION
REGULATIONS
1984-1991

REGULATIONS 
DATABASE AND DATES

COVERED
DESCRIPTION PRINCIPAL SOURCES
PRODUCER AND

HARD COPY COUNTERPART
VENDOR AND/OR

DATABASE INQUIRIES
FEDERAL NEWS SERVICE

1991-
Full text information of federal government press briefings, speeches, and interviews/

Speeches, calendar of events, interviews, transcripts
Federal Information Systems

Corporation
L

Full text of the FEDERAL U.S. Government Printing Office L, M
REGISTER/

FEDERAL REGISTER

1988
FEDERAL REGISTER
FEDERAL REGISTER

FEDERAL RESEARCH IN
PROGRESS
Current

Current
Information about ongoing federally-funded research projects in the fields of physical sciences, engineering and life sciences/
National Technical Information Service (NTIS)
L

Research summaries

\section{FHGPUBLICA}

1980-
References to publications of the Fraunhofer Society Institute in the areas of microelectronics, sensor technology, automated production, and building materials/
Information Center for Regional STN Planning and Building Construction of the Fraunhofer Society (Germany)

Books, journals, conferences, reports, bibliographies

\section{FI DEFENSE MARKET \\ INTELLIGENCE REPORTS \\ Current}

Full text intelligence reports relating to the defense industry/
Forecast International/DMS

$\mathbf{L}$

Reports

\section{FUJI-KEIZAI MARKET RESEARCH Current}

Full text market research reports focusing on the high technology market in computers and communications/

Market research reports
FINANCIAL TIMES BUSINESS REPORTS EASTERN EUROPE DATABASE

1992-
Full text news and comment on political and economic developments throughout Eastern Europe/
Fuji-Keizai USA

L

Newsletters

Financial Times Information DS 


\section{DATABASE AND DATES COVERED}

DESCRIPTION/

PRINCIPAL SOURCES
PRODUCER AND

HARD COPY COUNTERPART
VENDOR AND/OR

DATABASE INQUIRIES
FINANCIAL TIMES BUSINESS

REPORTS ENERGY AND

ENVIRONMENT

1990-
Full text of detailed and authoritative analysis of energy and environment markets and issues/

Newsletters, reports
Financial Times Information Services (U.K.)

DS
Various FINANCIAL TIMES

newsletters and reports
FINANCIAL TIMES BUSINESS REPORTS FINANCIAL MANAGEMENT AND INSURANCE 1990-
Full text news and editorial comment on all aspects of financial services, financial management, and insurance/

Newsletters, journals
Financial Times Information

DS
Various FINANCIAL TIMES

business and financial newsletters
FINANCIAL TIMES BUSINESS REPORTS INDUSTRY 1992
Full text news and comment on market and product developments in the pharmaceuticals and biotechnology industries/
Financial Times Business Information (U.K.) DS

Reports, newsletters

News and analysis of product, company and market trends in telecommunications, office technology and the communications media worldwide/

Journals, newspapers
FINANCIAL TIMES BUSINESS REPORTS TECHNOLOGY 1990-
Complete text of all articles published in the London and international edition of the

FINANCIAL TIMES newspaper/

Newspaper

Full text of Belgium's leading financial daily newspaper/

Newspaper

Complete text of market research reports/
Financial Times Information

DS
Financial Times Business

Information, Ltd. (U.K.)
L
DE FINANCIEEL EKONOMISCHE TIJD 1990
De Financieel Ekonomische

DS
FINANCIAL TIMES
DE FINANCIEEL EKONOMISCHE TIJD
FIND/SVP MARKET RESEARCH REPORTS

Current
FIND/SVP

L 
FINDEX

1985-
Describes industry and market research reports and studies commercially available from U.S. and non-U.S. publishers/

Surveys
Cambridge Scientific Abstracts

L
FINDEX: THE DIRECTORY OF MARKET RESEARCH REPORTS, STUDIES AND SURVEYS

\section{FIREDOC}

Mid 1981-
Reports, books, journal articles and audiovisual materials in the collection of the Fire Research Information Service at NIST/

Reports, books, journals, audiovisuals

FIRMIMPORT/FIRMEXPORT

Current
Profiles of French companies which export or import products/

Business data

FLIGHTLINE

Dec. 1988-
Full text of all aspects of the international aerospace industry/

Journals
FLUIDEX

1973-
International coverage of the literature of fluid engineering

Journals, books, proceedings, reports, standards, patents
Fire Research Information Service, Building and Fire Research Laboratory, National Institute of Standards and Technology (NIST)
Association Telexport (France)

DS
Janet Matthews Information Services (U.K.)

FLIGHT INTERNATIONAL, AIRLINE BUSINESS
Elsevier Science B.V. (U.K.)

L
F, NVL

DS

Various abstract sources
Literature of research and development in food science and technology/

Journals, patents, monographs
IFIS Publishing (U.K.)

DS, L, STN
NOLOGY ABSTRACTS (FSTA) 1969-
Worldwide literature on food science and technology/
Leatherhead Food Research Association (U.K.)
DS, L

Journals, books, patents, reports, standards, proceedings

FOOD SCIENCE AND TECHNOLOGY ABSTRACTS
1972 
DATABASE AND DATES

COVERED
DESCRIPTION/

PRINCIPAL SOURCES
PRODUCER AND

HARD COPY COUNTERPART
VENDOR AND/OR DATABASE INQUIRIES

FOODLINE: CURRENT FOOD
LEGISLATION
CurTent

FOODLINE: CURRENT FOOD

Current
Source of food additives, composition and labeling

legislation/

Laws, official sources, standards
Leatherhead Food Research

Association (U.K.)
DS, L
Information and statistics on worldwide food and beverage markets/

Journals, reports, statistical publications
Leatherhead Food Research Association (U.K.)
DS, L
FOOD MARKET DATA

1982-
Literature on the examination of evidential materials, analytical methods, and the presentation and interpretation of findings/

Journals
Information relating to food

industry developments/

Journals
General Mills

FOODS ADLIBRA
The Forensic Science Service (U.K.)
L

FORENSIC SCIENCE 1976-
DS
Descriptions of nongovernmental, nonprofit organizations/

Reports
Current, planned and research projects in the social sciences carried out in the Federal Republic of Germany, Austria and Switzerland/

Research projects
Informationszentrum

Sozialwissenschaften (Germany)
FORIS

$1980-$
Descriptions of research and technology development projects supported by the Federal

Ministry for Research and Technology/

Projects
Der Bundesminister für Forschung und Technologie
FORK
1986
STN

\section{FOUNDATION DIRECTORY Current}

L

The Foundation Center

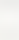

L


FOUNDATION GRANTS INDEX

1973-
Information on grants by nongovernmental, nonprofit foundations/

Reports, news releases

Germany's national daily newspaper/

\section{ZEITUNG}

1993-
The Foundation Center

L

FOUNDATION NEWS

Frankfurter Allgemeine Zeitung

DS

Newspaper

FRANKFURTER ALLGEMEINE ZEITUNG

FREEDONIA MARKET RESEARCH 1990
Full text industry studies, business research reports and corporate intelligence reports/

Reports, studies
The Freedonia Group, Incorporated
DS, L
S\&W (France)

DS

\section{FRENCH COMPANIES-FULL FINANCIAL INFORMATION Current}

Balance sheets and profit and loss information for about 100,000 French companies/

Company accounts
Full text of Frost \& Sullivan market research reports/
Frost \& Sullivan

DS, L

\section{RESEARCH}

$1990-$

Reports

FTN

1976-
Bibliographic database covering reports on publicly funded research projects in science and technology in the Federal Republic of Germany/

Reports
FIZ Karlsruhe (Germany)
FORSCHUNGSBERICHTE

AUS TECHNIK UND

NATURWISSENSCHAFTEN
GALE DATABASE OF

PUBLICATIONS AND BROADCAST MEDIA

Current edition
Comprehensive information on 65,000 newspapers, magazines, journals, periodicals, directories, newsletters, radio, TV and cable systems/.

Questionnaires, telephone calls
Gale Research, Incorporated

L
GALE DIRECTORY OF PUBLICATIONS AND BROADCAST MEDIA; DIRECTORIES IN PRINT; CITY AND STATE DIRECTORIES IN PRINT; NEWSLETTERS IN PRINT 
GALE DIRECTORY OF ONLINE, PORTABLE, AND INTERNET DATABASES

Current
Information about online

databases/
Gale Research, Incorporated

DS, L

Databases

GALE DIRECTORY OF DATABASES; CYBERHOUND'S GUIDE TO INTERNET DATABASES

GENBANK

1982-
Nucleic acid database containing references/

Journals, unpublished sources sequences, descriptive data, and
National Center for Biotechnology

STN
Information
Haymarket Medical, Ltd. (U.K.) DS

Full text of three major publications aimed at the medical practitioner/

Journals

GP-GENERAL PRACTITIONER;

MIMS MAGAZINE; MEDECO-

NOMICS

\section{GENERAL SCIENCE ABSTRACTS}

FULL TEXT

May 1984

Jan. 1995- (full text)
Literature on all areas of sciencel
H.W. Wilson Company

L

Journals

International coverage of the literature of the geosciences/

Journals, books, proceedings, reports
Geosystems (U.K.)

L
Worldwide literature on geography, geology, ecology and related disciplines/

Journals, books, proceedings, reports
Elsevier Science B.V. (U.K.)

FI, L 
GEOREF (GEOLOGICAL REFERENCE FILE)

1785-
Worldwide coverage of the literature of the geosciences/

Journals, proceedings, symposia, theses
American Geological Institute

FI, L, STN
THE GERMAN INDUSTRY Current
Detailed information on 18,000 major export-oriented German companies and their products/
BIBLIOGRAPHY AND INDEX OF GEOLOGY; GEOPHYSICAL ABSTRACTS; BIBLIOGRAPHY AND INDEX OF NORTH AMERICAN GEOLOGY; BIBLIOGRAPHY OF THESIS IN GEOLOGY; BIBLIOGRAPHY AND INDEX OF GEOLOGY EXCLUSIVE OF NORTH AMERICA
GFI (GMELIN FORMULA INDEX) 1817-1975

1983-
Formula index and complete catalog supplements to GMELIN HANDBOOK OF INORGANIC CHEMISTRY/

Chemical data
ABC der Deutschen Wirtschaft Verlagsgesellschaft $\mathrm{mbH}$ (Germany)
Gmelin Institute for Inorganic Chemistry (Germany)

DS, STN

FORMULA INDEX FOR THE

GMELIN HANDBOOK OF

INORGANIC CHEMISTRY;

GMELIN COMPLETE CATALOG

\section{GIDEP (GOVERNMENT-INDUSTRY DATA EXCHANGE PROGRAM) 1970}

Cooperative activity between government and industry to exchange technical data/
GIDEP

G

Reports, engineering, metrology, failure and safety data

Index of public documents of the Federal Government

Reports, hearings, laws, bills
Government Printing Office (GPO)

MONTHLY CATALOG OF U.S. GOVERNMENT PUBLICATIONS
GPO PUBLICATIONS REFERENCE FILE 1971-
List of public documents currently for sale by the Government Printing Office/
Government Printing Office (GPO)
STN

OG

GPO MONTHLY CATALOG July 1976-

Reports 


$\begin{array}{lll}\begin{array}{l}\text { GRANTS } \\ \text { Current }\end{array} & \begin{array}{l}\text { Grant programs offered by } \\ \text { government and nongovernment } \\ \text { organizations/ }\end{array} & \text { Oryx Press } \\ & \text { Directories, bulletins } & \text { GRANT INFORMATION } \\ & & \text { SYSTEM, FACULTY ALERT } \\ & \text { BULLETIN }\end{array}$

\section{HARVARD BUSINESS REVIEW/ ONLINE (HBRO) \\ 1971-}

Full text coverage of HARVARD BUSINESS REVIEW'S complete range of management subjects/

\section{HARVARD BUSINESS REVIEW}

Harvard Business School

Publishing

\section{HARVARD BUSINESS REVIEW}

L

\section{HEALSAFE}

1981-

\section{Literature on public health,} safety, and industrial hygiene/

Theses, reports, patents, journals, proceedings
Cambridge Scientific Abstracts

STN
DS, L

\section{HEALTH AND SAFETY}

SCIENCE ABSTRACTS

\section{HEALTH (HEALTH PLANNING AND ADMINISTRATION) 1975-}

International literature of the nonclinical aspects of health care delivery/

Journals, monographs, symposia
National Library of Medicine

DS, L

\section{HOSPITAL LITERATURE} INDEX

\section{HEALTH DEVICES ALERTS} 1977-
Comprehensive coverage of reported medical device problems, hazards, recalls, evaluations, and updates/

Journals, reports
ECRI

L
Directory containing current address and marketing information on the North American manufacturers and distributors of more than 4000 classes of medical devices/

Mailings, interviews
ECRI

L

\section{SOURCEBOOK}

Current 
HEALTH NEWS DAILY

March 1989-
Full text of HEALTH NEWS

DAILY covering events in

the healthcare industry/

HEALTH NEWS DAILY
F-D-C Reports, Incorporated

DS, L

\section{HEALTH NEWS DAILY}

Literature in the areas of health, medicine, fitness, and nutrition/

Journals
Information Access Company

DS
Literature on the clinical and nonclinical aspects of healthcare/

Journals, reports, monographs, newspapers

Worldwide coverage of the literature of history and related social sciences and humanities/

Journals
U.S. National Library of Medicine/ American Hospital Association

DS, L

HOSPITAL AND HEALTH ADMINISTRATION INDEX
HISTORICAL ABSTRACTS 1954
ABC-CLIO, Incorporated

L

HISTORICAL ABSTRACTS: PART A, MODERN HISTORY ABSTRACTS PART B, TWENTIETH CENTURY ABSTRACTS
HODOC

Current
Numeric file providing physical and chemical data on organic compounds/

Chemical data
CRC Press

STN

CRC HANDBOOK OF DATA ON ORGANIC COMPOUNDS

\section{HOPPENSTEDT AUSTRIA}

Current
Descriptions of over 3000 major companies in Austria/

Company data
Hoppenstedt Wirtschaftdatenbank GmbH (Germany)

OESTERREICH 2000
HOPPENSTEDT BENELUX

Current
Profiles of 77,000 companies in the Netherlands, Belgium, and Luxembourg/
$\mathrm{ABC}$ voor Handel en Industrie C.V. DS 


\section{HOPPENSTEDT DIRECTORY OF GERMAN COMPANIES \\ Current}

A directory file for 36,000

German companies/

Directory data
Hoppenstedt Wirtschaftdatenbank DS, L

GmbH (Germany)

HANDBUCH DER

GROSSUNTERNEHMEN;

HANDBUCH DER

MITTLESTAENDISCHEN

UNTERNEHMEN

$\begin{array}{lll}\text { HSDB (HAZARDOUS SUBSTANCE } & \text { Toxicity data on more than } & \text { National Library of Medicine } \\ \text { DATA BANK) } & 4300 \text { substances/ } & \text { DS, STN }\end{array}$

Current 4300 substances

Health and Safety Executive

DS

HSELIN

Health and safety aspects of

manufacturing industries, agri-

(U.K.)

culture, engineering, mining, etc./

Reports, journals, books,

proceedings, patents, standards

HUMANITIES ABSTRACTS

Literature of the humanities/

H.W. Wilson Company

FI, L

FULL TEXT

1984

1995- (full text)

Journals

IAC AEROSPACE/DEFENSE

MARKETS \& TECHNOLOGY

1982-
Coverage of aerospace and defense journals/
Information Access Company

DS, L

Journals

IAC BUSINESS A.R.T.S.

1976-
Scholarly business database with some full text focusing on the social, culture, political, and

psychological aspects of business/

Journals
Information Access Company

DS, L
Worldwide business and economics research/

Journals, reports, newspapers, bank letters
Information Access Company

DS, $\mathbf{L}$
1978-

\author{
CHANGE; F\&S INDEX INTERNA- \\ TIONAL; F\&S INDEX EUROPE
}

F\&S INDEX OF CORPORATE 
IAC GLOBALBASE

1985-
Business news articles/

Information Access Company

DS, L

Newspapers, journals

IAC HEALTH \& WELLNESS

DATABASE

1976-
Broad coverage with some full text in the areas of health, medicine,

fitness, and nutrition/

Books, pamphlets, journals, newsletters
Information Access Company

L

Information Access Company

L

Late-breaking coverage of specialized, high-value trade and business publications/

Journals

Index to legal and law-related literature/

Information Access Company

DS, L

1980

Journals, newspapers

LEGAL RESOURCE INDEX (COM); CURRENT LAW INDEX

Marketing and advertising of consumer goods and services/

Information Access Company

DS, L TISING REFERENCE SERVICE 1984

Journals, newsletters, newspapers

Full text of news releases issued by companies on new products/

Information Access Company

DS, L
IAC NEW PRODUCT

ANNOUNCEMENTS

1985-

News releases

Daily-updated file from nine Information Access Company (IAC) databases in the areas of business, computers, health, law, management, and current events/

Journals, newspapers, wires
Information Access Company

L
Current 
DATABASE AND DATES COVERED
DESCRIPTION

PRINCIPAL SOURCES
PRODUCER AND

HARD COPY COUNTERPART
VENDOR AND/OR

DATABASE INQUIRIES
IAC NEWSLETTER DATABASE
1988-
Full text of specialized industry newsletters/

Newsletters
Information Access Company

Various newsletters
Full text of wire stories from many worldwide news sources/

Wire service
IAC NEWSWIRE ASAP

1985
Full text of international trade publications in pharmaceuticals, biotechnology and health care/

Journals
Information Access Company

L

\section{IAC PHARMABIOMED BUSINESS JOURNALS 1990}

Coverage of companies, products, markets, and applied technologies for manufacturing and service industries'

Newspapers, reports, journals
IAC PROMT

1972-
Information Access Company

DS, L, STN
DS
Full text of the annual reports
ICC Information, Ltd. (U.K.)
DS, L and accounts produced by the leading 500 European quoted companies and all U.K. quoted companies/

Annual reports

$\begin{array}{ll}\text { ICC BRITISH COMPANY } & \text { Full text of the annual reports } \\ \text { ANNUAL REPORTS } & \text { and accounts produced by the } \\ \text { Current } & \text { leading } 500 \text { European quoted } \\ & \begin{array}{l}\text { companies and all U.K. quoted } \\ \text { companies/ }\end{array}\end{array}$
ANNUAL REPORTS

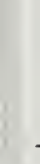

Directory and comprehensive information on companies in Scotland, England and Wales/

Financial data, directory information
ANNUAL REPORTS AND ACCOUNTS

\section{BRITISH COMPANY Current}

Commercial and financial information on 60,000 British companies/
ICC Information, Lid. (U.K.) ～DS, L

\section{ICC BRITISH COMPANY FINANCIAL DATASHEETS Current}

ICC Information, Ltd. (U.K.)

DS, L

Financial data 
ICC INTERNATIONAL BUSINESS RESEARCH Current
Full text information from bank and brokerage reports, annual reports and the "key note" series of marketing information reports/

Reports
ICC Stockbroker Research, Ltd.;
L
Detailed market information on 175 U.K. industry sectors/

Reports

Detailed company and industry analysis from stockbrokers/

Reports
Key Note, Ltd. (U.K.)

DS

ANALYSIS

Current

\section{ICC STOCKBROKER RESEARCH 1987-}

Stockbroker Research, Ltd. (U.K.)
Worldwide literature on all fields of building construction, construction engineering, architecture and town planning/

Journals, reports, books, proceedings, non-conventional literature
Information Center for Regional

STN Planning and Building Construction of the Fraunhofer Society (Germany)
1976-
Complete evaluated structural information for inorganic compounds/

Journals

\section{ICSD (INORGANIC CRYSTAL RUCTURE DATABASE) 1912-}

Literature relating to drugs and drug therapy in humans/
Iowa Drug Information Service

DS 1966-

Journals

FIZ Karlsruhe (Germany)

STN
Index and full text of IEEE/IEE publications/

Journals, proceedings, standards
Information Handling Services

IEEE/IEE publications 1989-

Industry, military, and federal specifications and standards/
Information Handling Services

L AND SPECIFICATIONS

Current

\section{Standards}

*Available only in CD-ROM format from the producer 
IMMUNOCLONE DATABASE

1986-
Data about cells of immunological interest, such as hybridomas, $\mathrm{T}$-cell clones, and monoclonal antibodies/

Catalogs, patents, journals, hybridoma collections
CERDIC (France)

DS
Profiles about 7000 pharmaceutical IMS Global Services (U.K.) DS, L and chemical manufacturing companies operating in healthcare markets around the world/

Company information
IMSWORLD DRUG MARKET

MANUAL-COMPANIES

DIRECTORY

\section{IMSWORLD DRUG MARKETS \\ Current}

Overview of pharmaceutical industry and health care provisions in 76 countries/

Journals, reports, company information

Worldwide pharmaceutical product information/
IMS Global Services (U.K.)

DS

\section{IMSWORLD NEW PRODUCT LAUNCH LETTER 1982-}

Original data

WORLD DRUG MARKET MANUAL-COUNTRIES

IMS Global Services (U.K.)

DS, L, STN
International evaluated pharma- $\quad$ IMS Global Services (U.K.) $\quad$ DS, L, STN ceutical product patent family datal

Patents, journals

$\begin{array}{ll}\begin{array}{l}\text { IMSWORLD PATENTS } \\ \text { 1987- }\end{array} & \begin{array}{l}\text { International evaluated pharma- } \\ \text { ceutical product patent family } \\ \text { datal }\end{array} \\ & \text { Patents, journals }\end{array}$

IMSWORLD PHARMACEUTICAL COMPANY PROFILES 1991-
Full text reports on pharmaceutical companies worldwide/

IMS Global Services (U.K.)
DS, L

\section{Reports}

\section{IMSWORLD PRODUCT MONOGRAPHS \\ Current}

Worldwide product information

on launched drugs/
IMS Global Services (U.K.)

DS, STN 
IMSWORLD R+D FOCUS

1977-
Latest scientific and commercial developments in international pharmaceutical $\mathrm{R}+\mathrm{D} /$

Company information, interviews, press releases
IMS Global Services (U.K.)

L, STN

\section{$\mathrm{R}+\mathrm{D}$ FOCUS}

News on international pharma-

IMS Global Services (U.K.)

DS, STN ceutical research and development/

June 1991-

Press releases, journals, newspapers, company reports, proceedings, direct company contacts

International coverage of forth-

IMS Global Services (U.K.)

DS

IMSWORLD R+D F
MEETINGS DIARY

coming pharmaceutical meetings/

Current

Journals, press releases, professional associations
INCIDENCE AND PREVALENCE

DATABASE

1988-
Incidence and prevalence data for more than 4,000 diagnoses and procedures/

Journals, reports, surveys

\section{INDEPENDENT (LONDON)}

Sept. 1988-
Complete text of the final edition of the INDEPENDENT newspaper/

Newspaper
Timely Data Resources

DS, L
Newspaper Publishing plc.

(U.K.)

THE INDEPENDENT (LONDON)
INDEX TO LEGAL PERIODICALS Index to the legal literature/ \& BOOKS

August 1981-
H. W. Wilson Company

FI

Journals, yearbooks, law reviews, government publications
INDUSTRY TRENDS AND

ANALYSIS

1977-
Index to the sources of the consulting firm Arthur D. Little, mainly in the area of management, technology and industry/
Decision Resources, Incorporated

$\mathbf{L}$

Reports 
INFO LATINO AMERICA

1988-
Worldwide literature on the contemporary, economic, political and social issues in Latin America/

Newspapers, journals

\section{INFOCHECK UK COMPANY FINANCIAL DATASHEETS Current}

Financial analysis and comment on over 400,000 registered UK companies/
National Information Services

Corporation
L

Reports, journals, newspapers

The Infocheck Group, Ltd.

(U.K.)
DS

Fachhochschule Potsdam

STN
Bibliographic database containing the relevant German and international literature in the field of information science/

Journals, books, reports, proceedings
Information in German concerning humanities, physical sciences, life sciences and engineering/

Questionnaires
INFOR (INFORMATION ABOUT RESEARCH IN THE FEDERAL STATE OF BADENWUERTTEMBERG) Current
Worldwide coverage of information science literature/

Reports, proceedings, journals patents, books

Profiles of 180,000 Belgium companies/

Reports, catalogs, journals, questionnaires, interviews
FIZ Karlsruhe (Germany)

STN

\author{
ABSTRACTS \\ 1966-
}

INFOTRADE BELGIUM COMPANY DATABASE Current
IFU/Plenum Data Company

L
INFORMATION SCIENCE ABSTRACTS

INFOTRADE (Belgium)

DS
INIS

1970-
Worldwide literature in nuclear research and technology/

Journals, reports, proceedings, books, patents
International Atomic Energy Agency STN 
INITIAL PUBLIC OFFERINGS 1980
Identifies U.S. companies issuing public stock and equity for the first time/

SEC filings, prospectuses, news sources, wires
Securities Data Company

L
Listing of worldwide patents $\quad$ European Patent Office L, STN in all areas of technology/

Patents
(Austria)

INPADOC PATENT GAZETTE
INPADOC

1968-
Up-to-date analyses of the important news on drugs and drug therapy/

Journals, press releases, reports, conferences
ADIS International, Ltd.

DS
1983-
Details of papers from conferences received at the British Library Document Supply Center/
British Library Document Supply Center
L

Oct. 1993-

Conference proceedings

INSIDER TRADING MONITOR 1984
Transaction details of all insider trading filings received by the SEC/
CDA Investment Technologies

L

SEC financial data

INSPEC

1969-
Worldwide coverage of the literature in physics, electrotechnology, computer and control engineering, and information technology/

Journals, technical reports, theses, proceedings, books, patents
Institution of Electrical Engineers (U.K.)

DS, FI, L, STN
PHYSICS ABSTRACTS (INSPEC A); ELECTRICAL AND ELECTRONIC ABSTRACTS (INSPEC B); COMPUTER AND CONTROL ABSTRACTS (INSPEC C); INFORMATION TECHNOLOGY (INSPEC D) 


\section{INSPHYS}

1979-1994
Bibliographic database covering worldwide literature on all fields of physics, astronomy, astrophysics and related fields/

Journals, books, reports, proceedings
The Institution of Electrical Engineers (U.K.)

PHYSICS BRIEFS/ PHYSIKALISCHE BERICHTE
Literature on insurance, Insurance Information Online DS reinsurance, risk management, loss adjustment, loss prevention, and insurance law/

Journals

\section{(Switzerland)}

\section{ONLINE}

$1987-$
Literature of the insurance

business/
NILS Publishing Company

L

\section{INDEX}

INSURANCE PERIODICALS

1984

Journals

Various directory publishers

L

Collection of important inter-

$\begin{array}{ll}\text { INTERNATIONAL BUSINESS } & \begin{array}{l}\text { Collection of important inter } \\ \text { national business directories }\end{array} \\ \text { DIRECTORY } & \end{array}$

Current
Directories
BUSINESS Datenbanken GmbH DS

(Germany)
INTERNATIONAL BUSINESS
OPPORTUNITIES SERVICE

Current
Worldwide business

opportunities/

Company and bank information

\section{INTERNATIONAL MARKET}

RESEARCH INFORMATION

1964
Worldwide market research information/

Norton Sterling Associates, Ltd. (U.K.)
DS

American Society of Health-System

DS, L, STN
International literature on all phases of drugs and pharmaceutical practices/

Journals, reports

\section{Pharmacists}

INTERNATIONAL PHARMACEUTICAL ABSTRACTS 
INTERNATIONAL PLASTICS

\section{SELECTOR DATABASE}

1977-
Manufacturer supplied data on mechanical, thermal, electrical and processing properties, flammability and uses for more than 12,000 commercial plastics/
Global/D.A.T.A Resources;

STN

Manufacturer specifications

Provides indicators of the stability and trading conditions in over 120 countries worldwide/

PAYMENT REVIEW

Current
Dun \& Bradstreet, Ltd. (U.K.)

DS

INTERNATIONAL RISK AND PAYMENT REVIEW

Official statistics, databases,

interviews

\section{INVESTEXT}

1982-
Full text of international industry and company reports generated by financial analysts of leading investment banking firms/
Thomson Financial Services

DS, L, STN

Business data

Full financial information on more than 250,000 Irish companies/

Government information, company's regist ration office
CFI Online, Ltd. (Ireland)

DS
Descriptions in German of computer programs for industryspecific and industry-wide commercial, technical and scientific applications available in Germany, Austria and Switzerland/

Reports

Listing of papers given at science and technology meetings/

Proceedings
Nomina Gesellschaft für

DS Wirtschafts und Verwaltungsregister mbH (Germany)

\section{ISTP}

1993-
Financial data on Italian companies/
Institute for Scientific Information

NVL TECHNICAL PROCEEDINGS

ITALIAN COMPANY PROFILES Current
Databank SpA (Italy)

DS 
News from Russia/

News
Comtex Scientific Corporation

L
JANAF

1959-1985
Critically evaluated chemical thermodynamic properties of inorganic and organic substances/

Property data
National Institute of Standards and Technology (NIST)

JANAF THERMOCHEMICAL TABLES
JANE'S DEFENSE AND AEROSPACE NEWS/ANALYSIS 1982-
International perspective on defense related topics/
Jane's Information Group (U.K.)

L
STN

\begin{tabular}{|c|c|c|c|}
\hline & Journals & JANE'S DEFENSE WEEKLY & \\
\hline $\begin{array}{l}\text { JAPAN ECONOMIC NEWSWIRE } \\
\text { PLUS } \\
1984\end{array}$ & $\begin{array}{l}\text { General and business news } \\
\text { from Japan and international } \\
\text { news that relates to Japan/ } \\
\text { Newswires }\end{array}$ & $\begin{array}{l}\text { Kyodo News International, } \\
\text { Incorporated (Japan) }\end{array}$ & $\mathrm{L}$ \\
\hline $\begin{array}{l}\text { JAPAN NEWS WIRE } \\
\text { 1986- }\end{array}$ & $\begin{array}{l}\text { Business and technical news } \\
\text { from Japan/ } \\
\text { Newspapers, journals, news } \\
\text { releases, government papers }\end{array}$ & $\begin{array}{l}\text { Comline Business Data, } \\
\text { Incorporated (Japan) } \\
-\end{array}$ & DS \\
\hline $\begin{array}{l}\text { JAPANESE GOVERNMENT } \\
\text { AND PUBLIC RESEARCH IN } \\
\text { PROGRESS } \\
5 \text { years of data }\end{array}$ & $\begin{array}{l}\text { Current and recently completed } \\
\text { research by public research } \\
\text { organizations in Japan/ } \\
\text { Questionnaires }\end{array}$ & $\begin{array}{l}\text { The Japan Information Center of } \\
\text { Science and Technology (JICST) } \\
\text { (Japan) } \\
\text { - }\end{array}$ & STN \\
\hline $\begin{array}{l}\text { JAPIO } \\
1976-\end{array}$ & $\begin{array}{l}\text { Japanese patent data for over } \\
1,000,000 \text { Japanese patent } \\
\text { records in English translation/ }\end{array}$ & $\begin{array}{l}\text { Japan Patent Information } \\
\text { Organization (Japan) }\end{array}$ & $\mathrm{L}, \mathrm{STN}$ \\
\hline 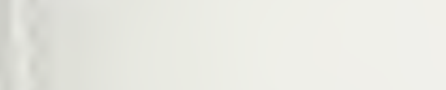 & Patents & $\begin{array}{l}\text { PATENT ABSTRACTS OF } \\
\text { JAPAN }\end{array}$ & \\
\hline
\end{tabular}




\section{JERUSALEM POST ELECTRONIC} EDITION

Oct. 1988-
Full text of the JERUSALEM POST, a daily newspaper which covers current events, business, and politics/

Newspaper

Literature from Japan on all fields of science, technology and medicinel

Journals, reports
The Jerusalem Post (Israel)

DS

THE JERUSALEM POST

The Japan Information Center of

DS, L, STN Science and Technology (JICST) (Japan)

\section{5-}

Information on over 95,000

British companies/

Information filed by each company, newspapers

Jordans, Ltd. (U.K.)

DS

Current

Full text of the world's leading daily newspaper for international trade and transportation/

Newspaper

Full text news from Japanese language sources and research/

Newspapers, journals, press releases, government statements
The Journal of Commerce, Incorporated

JOURNAL OF COMMERCE

COMLINE Business Data,

STN
L

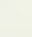

Complete text of reports focusing on the developing market of multimedia and interactive products and services/
Jupiter Communications

L
JUPITER MARKET RESEARCH Current

\section{Incorporated}

1986-

Reports

\section{KEY BRITISH ENTERPRISES} FINANCIAL PERFORMANCE Current
Financial information on the top 50,000 U.K. companies/

Questionnaires, telephone research, personal communication 
KIRK-OTHMER ONLINE

Current
Third and fourth edition of

Kirk-Othmer including index

entries, references, and tables/

Encyclopedia
Wiley Electronic Publishing

L

KIRK-OTHMER ENCYCLOPEDIA

OF CHEMICAL TECHNOLOGY

\section{KKF}

1973-
International literature on plastics and polymers/

Journals, books, proceedings

standards, reports
Deutsches Kunststoff-Institut

(Germany)

STN

Kompass International

L

Directory of approximately

167,000 companies in Asian

Neuenschwander SA (France)

and Pacific areas/

Directory information

Directory file providing

Micromedia (Canada)

L

business information for

35,000 Canadian companies/

Business data, personal visits,

phone interviews, media

surveys and questionnaires

\section{KOMPASS CANADA}

Directory information for over

100,000 Eastern European

countries/

Directory information
Kompass International

$\mathbf{L}$
KOMPAS
Current
Directory file of 210,000

European companies/

Directory information

Current

KOMPASS MIDDLE EAST/ AFRICA/MEDITERRANEAN

Current
Directory information for 80,000 companies in 11 countries/

Data from Kompass directories
Kompass International Neuenschwander SA (France)

Kompass International

L
L

\begin{tabular}{lll} 
KOMPASS ASIA/PACIFIC & $\begin{array}{l}\text { Directory of approximately } \\
\text { Current }\end{array}$ & $\begin{array}{l}\text { Kompass International } \\
\text { Neuenschwander SA (France) } \\
\text { and Pacific areas/ }\end{array}$ \\
& Directory information & \\
\hline
\end{tabular}

$$
\begin{aligned}
& \text { KOMF } \\
& \text { Currer } \\
& \text { KOMF } \\
& \text { Currer } \\
& \hline \text { KOMF } \\
& \text { Currer } \\
& \hline
\end{aligned}
$$

Currer

Neuenschwander SA (France) 
KOMPASS USA

Current

Directory information for over

53,000 U.S. companies/

Directory information
Kompass International

L Neuenschwander SA (France)
Literature concerning the cosmetics and perfume industries/
International Federation of the Society of Cosmetic Chemists (U.K.)
$1968-$

Reports, journals, proceedings

KR DEFENSE NEWSLETTERS

1989-
Full text defense-related

newsletters/

Newsletters
The Dialog Corporation

L
Full text newsletters on investments, finance, and banking/
The Dialog Corporation

L

1996-

Newsletters
NEWSLETTERS

1995- telecommunications industry/

Full text information on the
The Dialog Corporation

L

Various newsletters
DS

Financial information on Swedish companies'

Kreditfakta AB (Sweden)

Current

KREDITFAKTA COMPANY AIAL DATABASE
Newsletters

\& Registration Office and the

Commercial \& Registration

Office
Comprehensive information in

German on Austrian companies/
Kreditschutzverband von 1870 (Austria)
DS AUSTRIAN COMPANIES Current

Business data

Full text of 20 financial newsletters/
Janet Matthews Information Services (U.K.)
DS

\section{AND PROFESSIONAL SERVICES}

INTELLIGENCE

1994 
DATABASE AND DATES

COVERED

LANCET

1986-
DESCRIPTION/

PRINCIPAL SOURCES
PRODUCER AND

HARD COPY COUNTERPART
VENDOR AND/OR

DATABASE INQUIRIES
Full text of the medical weekly LANCET/

LANCET

Full text articles from Latin

American newspapers and

newsletters/

Newspapers, newsletters
The LANCET, Ltd. (U.K.)

DS, L
LATIN AMERICAN NEWS

Aug. 1994
Listing of monographic works of the Library of Congress/

\section{LANCET}

L

EL NORTE; REFORMA

\section{LC (LIBRARY OF CONGRESS)}

MARC

1968-
Monographs

Full text of the law from the various courts in the United

States and in the United

Kingdom; regulations/

Case law, slip opinions, slip

laws, regulations
Lexis-Nexis

M
U.S. Library of Congress

L

1890-(varies)

International literature in

library and information science/

Periodicals
Caselaw Publications; FEDERAL REGISTER; CODE OF FEDERAL REGULATIONS; etc.

\section{LIBRARY LITERATURE}

Dec. 1984
Worldwide literature on language and language behavior/

BEHAVIOR ABSTRACTS

1973-
Sociological Abstracts, Incorporated

Journals, monographs
H. W. Wilson Company

FI, L

\section{LINGUISTICS AND \\ LANGUAGE BEHAVIOR \\ ABSTRACTS; READING ABSTRACTS}

Bowker-Saur, Ltd. (U.K.)

L

\section{LISA (LIBRARY AND INFOR- MATION SCIENCE ABSTRACTS) 1969-}

Worldwide coverage of the literature of library and information science/

Journals, reports, monographs, proceedings

\section{LIBRARY AND INFORMATION SCIENCE ABSTRACTS}


LMS DRUG ALERTS 1983-
Summaries of key papers from the international literature on drugs, drug therapy, and adverse drug experiences/

Journals
Adis International, Ltd.

(New Zealand)
DS, L

\section{L}

Prentice-Hall Legal and Financial SEC Division

\section{M\&A FILINGS}

April 1985-
Detailed abstracts of every original and amended merger and acquisition document released by the SEC/

Merger and acquisition filings

Information on over 8000 fairs and exhibitions worldwide/ m\&a Publishers for Fairs, DS Exhibitions, and Conventions, Ltd. (Germany)

Directory information

MCGRAW-HILL PUBLICATIONS ONLINE

1985-
Full text of McGraw-Hill's leading magazines/
McGraw-Hill Companies

Publications Online
L

Magazines

McGraw-Hill Publications

Information Access Company

DS, L

MAGAZINE INDEX 1959-
Extensive coverage with some full text of the literature of current affairs, general news, and information/

Magazines
MAGAZINE INDEX (COM)

Salem Press, Incorporated

L

Full text articles on more than 1800 notable films from silent films to the present/

Film data
MAGILL'S CINEMA ANNUAL; MAGILL'S SURVEY OF CINEMA: FOREIGN LANGUAGE FILMS
MANAGEMENT AND MARKETING ABSTRACTS

1975-
Worldwide literature of management and marketing practice, customer and industrial relations/

Journals, newspapers, books, reports
Pira International (U.K.)

DS

\section{MANAGEMENT AND MARKETING ABSTRACTS}




\section{MANAGEMENT CONTENTS}

1974
Extensive coverage of the literature of business and management

Journals, proceedings, transactions, books, courses
Information Access Company

DS, L

\section{MANAGEMENT CONTENTS}

Management information on banking, finance, and the economy principally in the German-speaking countries/

Journals
Informationsrings Kreditwirtschaft

DS

\section{WIRTSCHAFT}

$1987-$
International literature on alternative healthcare/

Journals
Action Potential, Incorporated

DS
MANUAL, ALTERNATIVE, AND NATURAL THERAPY-MANTIS 1970

\section{that provide comprehensive analysis of the business to business market, concentrating on the utilities, engineering, construction and private health sections in the United Kingdom \\ Journals, government statistics, company information \\ DEVELOPMENT \\ Current}

Full text of research reports
Market \& Business Development,

DS
Ltd. (U.K.)

$-$

Business information on more

Databank SpA (Italy)

DS than 200 industrial and service

\section{sectors in Italy/ \\ Company information \\ TRENDS IN ITALY \\ Current}

Full text of the weekly publication MARKETLETTER which focuses on the pharmaceutical and healthcare industry/
Marketletter Publications, Ltd. (U.K.)
DS
Newsletter

Full text of MARKETLINE INTERNATIONAL MARKET REPORTS/

Reports
Marketline International (U.K.)

DS

\section{MARKETLINE MARKET REPORTS Current}

\section{MARKETLETTER}

\section{MARKETLINE INTERNATIONAL MARKET REPORTS}


MARKETSEARCH: INTERNATIONAL DIRECTORY OF PUBLISHED

MARKET RESEARCH

Current
Worldwide directory of market research studies/
Arlington Management Publications, Ltd. (U.K.)
DS

MARKETSEARCH: INTERNATIONAL DIRECTORY OF PUBLISHED MARKET RESEARCH
MARQUIS WHO'S WHO

Current
Detailed biographical information on outstanding professionals in all fields/

Biographical data

Full text database on the properties of drugs and medicines/

Drug data
Marquis Who's Who

$\mathbf{L}$

MARQUIS WHO'S WHO Series

\section{MARTINDALE PHARMACOPEIA}

Current
Royal Pharmaceutical Society of Great Britain (U.K.)

MARTINDALE, THE EXTRA PHARMACOPEIA
MATERIAL SAFETY LABEL DATA Current
Material Safety Data Sheet label information/

Material Safety Data Sheets
MDL Information Systems, Incorporated

DS

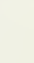


Worldwide publications in pure and applied mathematics/

Journals, proceedings, books
FIZ Karlsruhe (Germany)

STN

\section{ZENTRALBLATT FÜR} MATHEMATIK

Worldwide literature in mathe-

FIZ Karlsruhe (Germany)

STN matical education and related fields/

Journals, reports, books, proceed-

INTERNATIONAL REVIEWS

ings, non-conventional literature

EDUCATION

MATHSCI

1940
Worldwide literature on mathematics/

Journals, books, proceedings
American Mathematical Society

L, NVL*

MATHEMATICAL REVIEWS; CURRENT INDEX TO STATISTICS; INDEX TO STATISTICS AND PROBABILITY

\section{MDF}

1982-
Numerical information on all ferrous and non-ferrous metals and alloys/

Data
Materials Information

STN

\begin{tabular}{lll}
$\begin{array}{l}\text { MDIS COUNTRY HEALTHCARE } \\
\text { Current }\end{array}$ & $\begin{array}{l}\text { Market data on medical devices, } \\
\text { equipment, and healthcare services/ }\end{array}$ & MDIS Publications, Ltd. (U.K.) \\
& Market data & DS \\
\hline $\begin{array}{l}\text { MDX HEALTH DIGEST } \\
\text { 1988- }\end{array}$ & $\begin{array}{l}\text { Consumer-oriented health } \\
\text { articles/ }\end{array}$ & Medical Data Exchange \\
& Journals, newspapers, newsletters & \\
$\begin{array}{l}\text { MECHANICAL ENGINEERING } \\
\text { ABSTRACTS } \\
\text { 1973- }\end{array}$ & $\begin{array}{l}\text { Worldwide literature in the } \\
\text { fields of mechanical engineering } \\
\text { and engineering management }\end{array}$ & Cambridge Scientific Abstracts \\
& Journals & L, STN \\
& & MECHANICAL ENGINEERING
\end{tabular}

*Available also in CD-ROM format from 1980- 
MEDICONF

1993-
Comprehensive directory of

forthcoming conferences and

exhibitions in medicine, health

care, pharmaceuticals and

biotechnology/

Conference organizer information
FAIRBASE Datenbank GmbH

(Germany)
DS

FIZ Technik e.V. (Germany)

DS
MEDITEC: BIOMEDICAL ENGINEERING

1968-
International literature in

German on biomedical

engineering/

Journals, conference papers,

books, reports, thesis
National Library of Medicine

DS, FI, L, NVL, STN

Worldwide coverage of the literature of the biomedical sciences/

Journals, monographs

INDEX MEDICUS

International literature on all aspects of mental health and mental illness/

IFI/Plenum Data Corporation

L

1969

Journals, reports, proceedings, books
MERCK INDEX ONLINE

1889-
Descriptions of substances of chemical, biological, pharmaceutical and commercial interests/

Monographs

International literature of metallurgy/

Journals, proceedings, books, reports
Merck \& Co., Incorporated

L, STN

\section{MERCK INDEX}

Materials Information; Cambridge

DS, L, STN

\section{METADEX (METALS \\ 1966-}

Scientific Abstracts

METALS ABSTRACTS INDEX

ALLOYS INDEX; REVIEW OF METAL LITERATURE
METALCREEP

Current
Creep, stress and high temperature tensile properties for steels and aluminum alloys/

Property data
ASTM (The American Society

STN 
DATABASE AND DATES COVERED
DESCRIPTION/

PRINCIPAL SOURCES
PRODUCER AND

HARD COPY COUNTERPART
VENDOR AND/OR

DATABASE INQUIRIES

\section{METEOROLOGICAL AND GEOASTROPHYSICAL ABSTRACTS (MGA) \\ 1972-}

Worldwide literature of meteorological and geoastro-

physical research/

Journals, monographs, proceedings
American Meteorological Society

L

\section{METEOROLOGICAL AND GEOASTROPHYSICAL ABSTRACTS}

\section{MG FINANCIALSTOCK STATISTICS}

Current
Financial and stock trading information on public companies/

Reports, press releases, newswire services
Media General Financial Services,

L

(




\section{MONEYCLIPS}

Oct. 1989-
Information on business and

political affairs in the Middle East/

Newspapers, reports
Moneyclips, Ltd. (U.K.)

DS

Moody's Investor's Services,

L

Financial and business information

Incorporated on more than 3900 major corporations and institutions in 100 countries/

Financial data
MOODY'S INTERNATIONAL NEWS REPORTS

\section{MOODY'S CORPORATE NEWS-}

U.S.

1983-
Financial and business information on 13,000 publicly held U.S. corporations/
Moody's Investor's Services, Incorporated
Various Moody's News Reports
Financial data
Moody's Investors Services,

L

Descriptive and financial information on the most important publicly held U.S. companies/
Incorporated

\section{PROFILES}

Current

Financial data

MOSCOW NEWS

1992-
MOTOR INDUSTRY RESEARCH ASSOCIATION

July 1980-
Full text newspaper on current affairs in Russia/

Newspaper
Moskovskiye Novosti JSC

(Russia)

MOSCOW NEWS
Literature on all aspects of automobile engineering/

Newspapers, journals, proceedings, standards
The Motor Industry Research

Association (U.K.)
DS

DS

Canadian Centre for Occupational

STN

Occupational safety and health data for over 65,000 Canadian and U.S. products used in

Canadian workplaces/

Material safety data sheets

\section{Current}

Full text of industrial and business research of the United Kingdom and other European markets/
Marketing Strategies for Industry, DS 
NAPRALERT

$1650-$
Bibliographic and factual data on natural products/
Program for Collaborative Research

STN

University of Illinois at Chicago

Books, reports, journals, newsletters, patents

Index to articles in major newspapers/

Newspapers

(n)
Information Access Company

DS, L

NATIONAL NEWSPAPER INDEX 1979-
NATIONAL NEWSPAPER INDEX (COM)

\section{NCJRS (NATIONAL CRIMINAL JUSTICE REFERENCE SERVICE) 1972-}

International literature of criminal justice and law enforcement/
National Criminal Justice

Reference Service
L

Journals, reports

Monitors the progress of all drugs and biologics undergoing clinical development for use in the United States/

Telephone interviews, reports, journals, press releases, SEC filings
F-D-C Reports, Incorporated

DS, L

NDA

Database of Internet resources/

OCLC, Incorporated

FI

Worldwide web pages, discussion groups, FTP sites, Gopher servers, electronic publications

NETFIRST

Current

Daily newspaper of same name (in German) and includes monthly publications NZZ FOLIO and SWISS REVIEW OF WORLD AFFAIRS/

Newspaper
Verlag für die Neue Zuercher

Zeitung (Switzerland)
DS
Full text of the NEW ENGLAND JOURNAL OF MEDICINE

NEW ENGLAND JOURNAL OF MEDICINE
NEUE ZUERCHER ZEITUNG;

NZZ FOLIO; SWISS REVIEW

OF WORLD AFFAIRS
THE NEW ENGLAND JOURNAL OF MEDICINE 1985-
Massachusetts Medical Society

DS, L 
DATABASE AND DATES

COVERED

DESCRIPTION

PRINCIPAL SOURCES
PRODUCER AND

HARD COPY COUNTERPART

VENDOR AND/OR

DATABASE INQUIRIES
NEW YORK TIMES

1969-
Full text news and editorial information from the NEW YORK TIMES/

Newspaper

Complete text of three newspapers/

Newspapers
New York Times

DS, L, M
NEW ZEALAND NEWSPAPERS

1995-
Independent Newspapers, Ltd.

(New Zealand)

THE PRESS; THE DOMINION; SUNDAY STAR-TIMES

\section{NEWSPAPER ABSTRACTS}

1984
Index to articles from 19 major regional, national, and international newspapers/

Newspapers
UMI

FI, L
L 
NIST THERMODYNAMIC PROPERTIES OF REFRIGERANTS AND REFRIGERANT MIXTURES (REFPROP)

Version 4.0
Thermodynamic and transport properties of 38 pure refrigerants and refrigerant mixtures/
National Institute of Standards and Technology (NIST)
National Institute of Standards and Technology (NIST) and auger spectroscopy of organic and inorganic compounds/

Spectral data

\section{NIST X-RAY PHOTOELECTRON SPECTROSCOPY DATABASE Version 1.0}

Refrigerants

\section{NIST STRUCTURES AND PROPERTIES DATABASE AND ESTIMATION PROGRAM Version 1.2}

Thermochemical data from the ion energetics and chemical kinetics databases and the JANAF thermochemical data/

Chemical property data
National Institute of Standards and Technology (NIST)
$*$
NISTCERAM
$1972-1990$
Evaluated thermal and mechanical property data for silicon carbides and silicon nitrides/

Property data
National Institute of Standards

STN and Technology (NIST); Gas

Research Institute

\section{NISTFLUIDS \\ 1986}

Thermophysical and transport properties of twelve organic fluids/

Property data

Recommended values for selected thermodynamic properties for inorganic and simple organic substances/

Property values

\section{NISTTHERMO 1962-1982}

National Institute of Standards and Technology (NIST)

NBS TECHNICAL NOTE 1097
National Institute of Standards

STN
STN and Technology (NIST)

\section{NIST TABLES OF CHEMICAL THERMODYNAMIC PROPER- TIES/DATA FILES OF THE THERMODYNAMIC RESEARCH CENTER}

\section{NME EXPRESS}

1993-
Information on new molecular entities revealed for the first time in the literature/

Journals, congresses, company communications
Prous Science Publishers (Spain)

DS, L 
NTIS

1964
Government-sponsored research and development including sciences, technology, and regulatory matters/

Technical reports
National Technical Information Service

WEEKLY GOVERNMENT REPORTS, GOVERNMENT REPORTS ANNOUNCEMENTS
DS, L, NVL, STN*

U.S. Department of Energy;

L
Comprehensive international information on nuclear science technology/

Journals, reports, proceedings, books, patents, thesis
National Technical Information

Service

NUCLEAR SCIENCE ABSTRACTS

NURSING AND ALLIED
HEALTH
1983-

NURSING AND ALLIED

1983-
Broad coverage of the literature of nursing, allied health and health care/

Journals
CINAHL Information Systems

DS

\section{CUMULATIVE INDEX TO NURSING AND ALLIED HEALTH LITERATURE}

OAG ELECTRONIC EDITION

Current
Flight information and fares for North American travel/

Travel information
Official Airline Guides, Incorporated
L

National Institute for Occupational L safety and health field/
Safety and Health (NIOSH); National

Technical Information Service 1973-

Journals, reports
OCEANIC ABSTRACTS 1964

\begin{tabular}{|c|c|}
\hline $\begin{array}{l}\text { Worldwide literature on marine- } \\
\text { related subjects/ }\end{array}$ & Cambridge Scientific Abstracts \\
\hline $\begin{array}{l}\text { Journals, proceedings, books, } \\
\text { reports }\end{array}$ & OCEANIC ABSTRACTS \\
\hline
\end{tabular}

THE OFFICIAL REGISTER OF CZECH AND SLOVAK ORGANIZATIONS

Current
Profiles of all licensed legal entities in the Czech Republic and Slovakia/
Albertina Global Data, Incorporated (Czech Republic)
Official government information 
OCLC

1968-
Descriptive information on books and serials added to the Library of Congress and other libraries throughout the country/

Books, serials
OCLC, Incorporated

O

\section{OHS MSDS}

1984-
Material Safety Data Sheets (MSDS) for thousands of the most commonly used chemicals and chemical mixtures/

Material Safety Data Sheets
MDL Information Systems, Incorporated
L, STN*
Deutscher Addressbuch-Verlag

DS

Information on 57,500 German companies and their products/ für Wirtschaft und Verkehr $\mathrm{GmbH}$

(Germany)

\section{THE ONLINE CATALOG 1960}

Online catalog listing of the books, journals, proceedings, and reports which are in the National Institute of Standards and Technology's (NIST) Research Information Center (RIC) Collection/

Books, journals, proceedings, reports
National Institute of Standards

Library

Literature on all aspects of packaging/

Journals, books, reports, proceedings, standards, patents, legislation
Fraunhofer Institut für Lebensmitteltechnologie und Verpackung

PACKAGING SCIENCE AND TECHNOLOGY ABSTRACTS

\section{AGING SCIENCE AND \\ $1982-$}

Comprehensive coverage of all fields of social sciences, including political science, banking, public administration, etc. $/$

Journals, monographs, pamphlets, government publications
Public Affairs Information Service

DS, FI, L
AFFAIRS INFORMATION SERVICE) 1972-
International literature of the pulp, paper, and board manufacturing industries/

Journals, patents, proceedings
Institute of Paper Science and

L, STN
$1967-$

ERCHEM

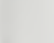




\section{PAPERS}

Coverage varies
Full text of various newspapers/

Newspapers

Index of papers presented at

conferences/

Conferences

Individual newspaper publishers

L

Various newspaper

OCLC, Incorporated

FI

1993-

Worldwide scientific and technical literature/

1973
German patents in science and technology, patent applications and utility models/
Institut de l' Information

Scientifique et Technique

(France)

BIBLIOGRAPHIE INTERNATIONALE
PATDPA

1968reports, books, patents
Journals, proceedings, theses,
Deutsches Patentamt (Germany)

STN
Patents
PATOSDE (PATENT-ONLINESYSTEM DEUTSCHLAND) 1968-
German Patent Office's patent applications, granted patents and utility models in the areas of science and technology/

\section{Patents}

PATOSEP (PATENT-ONLINESYSTEM EUROPA)

1978-
Extracts from patent applications and granted patents published

by the European Patent Office/

Patents
Wila Verlag (Germany)

STN
STN
DS, L 


\section{PDLCOM}

Current
25,000 test records on chemical and environmental compatibility of plastics/
Plastics Design Library

STN

Test data

Detailed descriptions of specific defense programs and their costs/

Forecast International/DMS

L
PEDS: DEFENSE PROGRAM

SUMMARIES

1989-
Program descriptions

Cover-to-cover indexing and abstracting with some full text

UMI

FI, L

reference publications/

\section{Periodicals}

PESTICIDE FACT FILE

Current
Factual data compilation on pesticides/

Data
British Crop Protection Council

(U.K.)

PESTICIDES MANUAL; AGROCHEMICALS HANDBOOK
L

Occupational Health Services,

STN
Material safety data sheets (MSDS) for chemicals used in the manufacture of pesticides and other agricultural chemical products/

Material safety data sheets

Comprehensive file of degreegranting, post-secondary colleges and universities in the United States and Canadal

Admission's Office data
Peterson's Guides

L
DATABASE

Current year
Information on graduate and professional programs offered by accredited colleges and universities in the United States and Canadal

Survey data
PETERSON'S ANNUAL GUIDES/GRADUATE STUDY
GUIDE TO FOUR-YEAR

COLLEGES; GUIDE TO

TWO-YEAR COLLEGES
L
PETERSON'S GRADLINE
Current
Peterson's Guides 
PNI (PHARMACEUTICAL NEWS INDEX)

1974
Current news about pharmaceuticals, cosmetics, medical devices/

Newsletters
UMI

L, STN

FDC REPORTS; DRUG

RESEARCH REPORTS; PMA NEWSLETTER; WASHINGTON DRUG AND DEVICE LETTER, etc.

Worldwide coverage of the literature of pollution and related topics/

Journals, technical reports, newspapers, government publications
POLLUTION ABSTRACTS
Comprehensive treatise of polymer science and engineering/

Encyclopedia
John Wiley and Sons, Incorporated

L

Current edition

\section{ENCYCLOPEDIA OF POLYMER SCIENCE AND ENGINEERING}

\section{POPULATION DEMOGRAPHICS} 1990 census
Statistical data on U.S. population, households, income, education, and occupations/

U.S. census information, demographic statistics
Market Statistics

L

PR Newswire Association, Incorporated

Complete text of news releases mainly business and financial

News releases
PR NEWSWIRE

May 1987-
An index of conference publications/

Conferences
OCLC, Incorporated

FI 1993-

Literature in the areas of business,

UMI

NVL
L
Coverage varies human resources, telecommunications, information systems, etc./

Journals, thesis, newspapers, magazines 
DATABASE AND DATES COVERED
DESCRIPTION/ PRINCIPAL SOURCES
PRODUCER AND

HARD COPY COUNTERPART
VENDOR AND/OR

DATABASE INQUIRIES
PSYCHINFO

1967-
Worldwide literature of psychology and the behavioral sciences/

Journals, reports, monographs

Full text of public opinion surveys conducted in the U.S./

Surveys

American Psychological Association

DS, FI, L

PUBLIC OPINION ONLINE

1936-
Information on the U.S. book publishing industry/
Roper Center for Public Opinion

Research
L
PUBLISHERS, DISTRIBUTORS AND WHOLESALERS

Current
R. R. Bowker

L

\begin{abstract}
Curtent

\section{QUEST ECONOMICS DATABASE 1992-}

THOLSALERS

Directory information

Directory information

PUBLISHERS, DISTRIBUTORS

AND WHOLESALERS OF THE

UNITED STATES
Full text compilation of British economic forecasts, commentary and analysis/

Forecasts, analyses
Janet Matthews Information

Services (U.K.)
DS
File of literary, political and
Oxford University Press (U.K.)
L
Quotations
THE OXFORD DICTIONARY OF QUOTATIONS \\ QUOTATIONS DATABASE \\ Biblical times-1979}

RAPRA Technology, Ltd. DS, L, STN $\begin{array}{lll}\begin{array}{l}\text { RAPRA ABSTRACTS } \\ 1972-\end{array} & \begin{array}{l}\text { Index to the world's polymer } \\ \text { literature/ }\end{array} & \begin{array}{l}\text { RAPRA Technology, Lt } \\ \text { (U.K.) }\end{array} \\ & \begin{array}{l}\text { Journals, proceedings, books, } \\ \text { reports, patents }\end{array} & \text { RAPRA ABSTRACTS }\end{array}$

$\begin{array}{lll}\begin{array}{l}\text { RAPRA ABSTRACTS } \\ 1972-\end{array} & \begin{array}{l}\text { Index to the world's polymer } \\ \text { literature/ }\end{array} & \begin{array}{l}\text { RAPRA Technology, Lt } \\ \text { (U.K.) }\end{array} \\ & \begin{array}{l}\text { Journals, proceedings, books, } \\ \text { reports, patents }\end{array} & \text { RAPRA ABSTRACTS }\end{array}$

$\begin{array}{lll}\begin{array}{l}\text { RAPRA ABSTRACTS } \\ 1972-\end{array} & \begin{array}{l}\text { Index to the world's polymer } \\ \text { literature/ }\end{array} & \begin{array}{l}\text { RAPRA Technology, Lt } \\ \text { (U.K.) }\end{array} \\ & \begin{array}{l}\text { Journals, proceedings, books, } \\ \text { reports, patents }\end{array} & \text { RAPRA ABSTRACTS }\end{array}$

$\begin{array}{lll}\begin{array}{l}\text { RAPRA ABSTRACTS } \\ 1972-\end{array} & \begin{array}{l}\text { Index to the world's polymer } \\ \text { literature/ }\end{array} & \begin{array}{l}\text { RAPRA Technology, Lt } \\ \text { (U.K.) }\end{array} \\ & \begin{array}{l}\text { Journals, proceedings, books, } \\ \text { reports, patents }\end{array} & \text { RAPRA ABSTRACTS }\end{array}$

$\begin{array}{lll}\begin{array}{l}\text { RAPRA ABSTRACTS } \\ 1972-\end{array} & \begin{array}{l}\text { Index to the world's polymer } \\ \text { literature/ }\end{array} & \begin{array}{l}\text { RAPRA Technology, Lt } \\ \text { (U.K.) }\end{array} \\ & \begin{array}{l}\text { Journals, proceedings, books, } \\ \text { reports, patents }\end{array} & \text { RAPRA ABSTRACTS }\end{array}$

$\begin{array}{lll}\begin{array}{l}\text { RAPRA ABSTRACTS } \\ 1972-\end{array} & \begin{array}{l}\text { Index to the world's polymer } \\ \text { literature/ }\end{array} & \begin{array}{l}\text { RAPRA Technology, Lt } \\ \text { (U.K.) }\end{array} \\ & \begin{array}{l}\text { Journals, proceedings, books, } \\ \text { reports, patents }\end{array} & \text { RAPRA ABSTRACTS }\end{array}$

\begin{abstract}
REACTIONS DATABASE 1983-
\end{abstract}

Coverage and analysis of all clinically relevant adverse drug use experiences/

Journals

Listing of bibliographic records for works cataloged by the Library of Congress/
Adis International, Ltd.

(New Zealand)

REACTIONS WEEKLY

ISM Library Information Services

L

REMARC (RETROSPECTIVE
MACHINE READABLE
CATALOGING)
1897-1980

(Canada)
DS

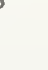




\section{RESEARCH CENTERS AND SER VICES DIRECTORY \\ Current edition}

Worldwide comprehensive source of detailed information on over 26,000 research organizations/

Questionnaires, telephone calls
Gale Research, Incorporated

L

\section{RESEARCH CENTERS DIRECTORY INTERNATIONAL RESEARCH CENTERS DIRECTORY; GOVERN- MENT RESEARCH DIRECTORY; RESEARCH SER VICES DIRECTORY}

\section{REUTERS}

1987 -
Access to current information on business and international news/

News stories
Reuters U.S., Incorporated

L
Literature in German on regional planning, town planning, housing, building construction and civil engineering/

Journals, books, proceedings, reports, non-conventional literature
Information Center for Regional STN STAEDTEBAU WOHNUNGSWESEN BAUWESEN) 1976-
Planning and Building Construction of the Fraunhofer Society (Germany)
Chemical toxicity data for 90,000 substances/ EFFECTS OF CHEMICAL SUBSTANCES) 1971-
National Institute for Occupational DS, L, STN Safety and Health (NIOSH); National Technical Information Service

Journals, reports, data

\section{REGISTRY OF TOXIC EFFECTS OF CHEMICAL SUBSTANCES}

\section{RUSSIAN AND CIS NEWS} 1990-
Current news, in-depth business and economic reports and legislative coverage of the new laws governing Russia and the CIS/

Reports, newspapers, journals, laws
IRIS-USA, Incorporated

DS
Listing of journals, journal articles, and libraries in all fields of science

and technology from the Russian Federation/

Journals, libraries
DATABASE

1991- 
SAE AUTOMOTIVE STANDARDS

Current
Standards, specifications, recommended practices, and reports of the Society of Automotive Engineers/

Standards, specifications, reports, recommended practices
SAE (Society of Automotive

DS
Worldwide literature gathered from industry, government, and academic sectors on self-propelled vehicles/

Journals, proceedings

Information on development project opportunities in the third world/

Journals

Multidisciplinary index to the literature of science and technology/

Journals

Financial profiles of over 3.5 million French companies/

Financial information from official sources
SAE (Society of Automotive Engineers) International

DS, L, STN
SAE QUARTERLY ABSTRACTS

Development Business Scan-a-Bid

DS
SCISEARCH (SCIENCE CITATION INDEX)

1974

SCRL FRENCH COMPANIES FINANCIAL PROFILES

Current
Information on all partial, completed, or rumored transactions that involve a change in ownership of at least five percent of the target's equity ownership/

Newspapers, wires, news releases, SEC reports, proxy statements, bank surveys
DEVELOPMENT BUSINESS

Institute for Scientific Information

DS, L, NVL, STN*

\section{SDC WORLDWIDE MERGERS}

1981-
Securities Data Company

DS, L

\footnotetext{
* Available in CD-ROM format from the producer from 1984
} 
SDC'S JOINT VENTURES AND ALLIANCES

1990
Agreements where two or more entities combine resources to form a new business/
Securities Data Company

L

Joint venture information

Directory information on about 70,000 Italian businesses involved in import and/or export on a regular basis/

Directory information
INFOCAMERE (Italy)

DS

SDOE/ITI
Current
SEC ONLINE

July 1987-
Synopsis of significant adverse drug reactions and interactions/

Reports
Full text database of reports filed by public companies with the U.S. Securities and Exchange

Commission/

SEC documents
Elsevier Science B.V.

(The Netherlands)
L

SEC Online, Incorporated

DS, L

SEDBASE

1996
Lists products in German and to which they are produced for companies in Germany, Austria, Switzerland, and the Netherlands/

Product information Directory information on all legal types of companies/ the DIN standards according

DITR (Germany)

DS

Current

Official sources

NORMTEILPRODUKTE

Sema Group InfoData AB

DS

(Sweden)

\section{COMPANIES}

Current
Serials in Swiss libraries/

SERIALS IN SWISS LIBRARIES

Current
Serials
Academic Suisse des Sciences

DS 
DATABASE AND DATES COVERED
DESCRIPTION/ PRINCIPAL SOURCES
PRODUCER AND

HARD COPY COUNTERPART
VENDOR AND/OR

DATABASE INQUIRIES
Descriptive information about medical serials/
National Library of Medicine

DS

Serials held by major U.S. medical libraries

SESAME

1975-
Current and completed energy

research and development

projects, demonstration projects,

and hydrocarbon technology

projects supported by the

Commission of the European

Communities or member states/

Current and completed projects
Commission of the European

Communities (Belgium)
STN
Non-conventional grey literature in the pure and applied sciences and technology/
European Association for Grey

Literature Exploitation

(Luxembourg)

Reports, dissertations, proceedings, books

SIGLE

1980
Full text articles exploring social, scientific, historic, economic,

political, and global issues/
SIRS, Incorporated

FI

SIRS R
1988-

Newspapers, magazines, journals, reports

Worldwide literature of the social sciences and humanities/

Journals
Institute for Scientific Information

DS, L
SOCIAL SCISEARCH

$1972-$
Literature on banking, economics, monetary problems, financial markets, etc./

Journals

\section{SOCIAL SCIENCES CITATION} INDEX

\section{SOCIETE GENERALE DE BANQUE 1979-}

Societé Generale de Banque

DS
Business Information Services

(Belgium) SOCIOLOGICAL ABSTRACTS
1963-
Worldwide literature in sociology and related disciplines/

Journals, monographs, theses, proceedings
Sociological Abstracts, Incorporated

DS, L 
SOFTBASE: REVIEWS, COMPANIES, AND PRODUCTS

1983-
Descriptions of business software packages for micro and minicomputers/

Software
Information Sources, Incorporated

DS, L
SOLE

Sept. 1984
Full text of II SOLE 24 ORE, Italy's leading financial daily newspaper/

Newspaper
24 ORE New Media (Italy)

DS

II SOLE 24 ORE
Literature on solid state physics, chemistry and engineering/

Journals, proceedings, reports
SOLIDSTATE

1981-
German language literature on the social sciences and their applications/

Journals, monographs

\section{SOUTH AMERICAN BUSINESS INFORMATION}

June 1996-
International newswire service covering the South American market
Informationzentrum

Sozialwissenschaften

(Germany)
Cambridge Scientific Abstracts

News

\section{Complete text of SOUTH CHINA MORNING POST/}

Newspaper
South China Morning Post (Hong Kong)
STN
DS, L

\section{2-}

\section{SOUTH CHINA MORNING POST}

SPEARHEAD

1985-
Guide to the European communities legislation/

Department of Trade and Industry (U.K.)
L

.

European community sources

Comprehensive reports covering 32 categories of specialty chemical industry segments/
SRI Consulting

L

\section{PROGRAM}

Nov. 1987-

\section{Reports}

DS

.


DATABASE AID DATES

COVERED

SPECINFO

Current
DESCRIPTION/

PRINCIPAL SOURCES
PRODUCER AND

HARD COPY COUNTERPART
VENDOR AND/OR

DATABASE INQUIRIES
Contains nmr and ir spectra for carbon, fluorine, phosphorus, nitrogen and oxygen/

Spectral data

Information on European community policies, initiatives and legislation/

Newsletters, periodicals, press releases, legal documentation
Chemical Concepts GmbH

(Germany)
STN

Consultancy Europe Associates,

DS

\section{DATABASE}

1987-
Worldwide coverage of the
American Institute of Physics

DS, L
L

\section{LA STAMPA \\ $1982-$}

Full text in Italian of LA STAMPA, one of Italy's leading daily newspapers/

La Stampa

In-depth strategic and financial information on more than 11,000 publicly held corporations/ literature of physics, as well as astronomy, astrophysics, and geophysics/
Journals, proceedings of AIP
(AIP)

\section{CURRENT PHYSICS INDEX}
Literature in the areas of sports, recreation, sports medicine, and physical education/
Sport Information Resource Centre (Canada)
SPORT
$1949-$
Journals, books, theses
SPORT AND RECREATION
INDEX
INFOR
$1975-$

STANDARD AND POOR'S CORPORATE DESCRIPTIONS PLUS NEWS

Current
La Stampa (Italy)

DS

Reports, press releases, newspapers

\section{STANDARD AND POOR'S}

DAILY NEWS

July 1985-
Information on companies including financial statements, sales, mergers/

Newspapers, reports, news releases, ticker services
Standard and Poor's Corporation

L
L

CUMULATIVE NEWS, DAILY NEWS 
STANDARD AND POOR'S REGISTER-BIOGRAPHICAL Current
Personal and professional data on business executives/

Biographical data
Standard and Poor's Corporation

L

STANDARD AND POOR'S REGISTER OF CORPORATIONS, DIRECTORS, AND EXECUTIVES
STANDARD AND POOR'S REGISTER-CORPORATE

Current
Business and financial information on more than 8,000 publicly-held

U.S. corporations/
Standard and Poor's Corporation

L

Reports, press releases

Full text of one of Germany's leading newspapers/

Newspaper
Sueddeutsche Zeitung (Germany)

DS
Full text of the World Bank and IDB Monthly Operational Summaries/

Operational summaries
Development Business Scan-A-Bid

DS SUMMARY
PROJECTS

Current

\section{SUEDDEUTSCHE ZEITUNG}

MONTHLY OPERATIONAL SUMMARIES OF THE WORLD BANK; QUARTERLY OPERATIONAL SUMMARY OF THE AFRICAN DEVELOPMENT BANK
SURFACE COATINGS ABSTRACTS 1976-
Worldwide coverage of the literature on all aspects of coatings applied to materials/

Journals, proceedings, books, patents
Paint Research Association (U.K.)

L

WORLD SURFACE COATINGS ABSTRACTS
TAX NOTES TODAY

1986-
Analytical summaries with the full text of all important legislative, regulatory, judicial and policy documents regarding federal taxation/

News stories, legislation, regulations, cases
Tax Analysts

L 
TECHNICAL STANDARDS

1918-
German-language standards/

Standards
DIN (Germany)

DS
DIN-KATALOG FÜR

TECHNISCHE REGELN

\section{TECHNIMETRICS EXECUTIVE} DIRECTORY

Current
Listing of business executives from public and private organizations/
Technimetrics, Incorporated

DS, L

Surveys, telephone contacts, business publications

TECHNIMETRICS SHARE/WORLD Current
Data on worldwide investment share ownership/

SEC filings, public documentation from mutual funds
Technimetrics, Incorporated

DS

Kernforschungszentrum Karlsruhe

STN
Worldwide projects and publications on the potential economic, environmental, and social impacts of the introduction of new or modified technologies/

Journals, surveys, books, reports
Profiles of 45,000 Japanese corporations/
Teikoku Databank America, Incorporated
DS, L
TEIKOKU DATABANK: JAPANESE COMPANIES

Current
Directory information

Directory of French companies/

Association TELEFIRM (France)

DS

\section{TELEFIRM}

Current

\section{Business data}

TENDERS ELECTRONIC DAILY Mar. 1992-
Details of invitations to tender for public supply and public works contracts/

Journal
Office for Official Publications of the European Communities (Belgium)

THE OFFICIAL JOURNAL OF THE EUROPEAN COMMUNITIES, SUPPLEMENT S
DS 
TEXTILE TECHNOLOGY DIGEST 1978-
International literature of the textile industry/

Journals, reports, books, theses, patents
Institute of Textile Technology

L
TEXTILE TECHNOLOGY DIGEST
TEXTLINE GLOBAL NEWS

1980-
Reuter's news from hundreds of international publications/

Newsletters, magazines, trade journals, newswires
Reuters, Ltd.

DS, L
Information on what is made in the United States, who makes it and where it is made/

Product and company information
Thomas Publishing Company, Incorporated

THOMAS REGISTER OF AMERICAN MANUFACTURERS
L Current edition
Comprehensive worldwide bank directory/
Thomson Financial Publishing

L

THOMSON/POLK BANKING

DATABASE

Current

Directory information

Catalog of the holdings of the Central Special Library for

Technology and Science

(Technische Informationsbibliothek)/

Journals, books, reports, proceedings, theses
Universitaetsbibliothek und TIB

STN
All journal holdings
Full text of Britain's oldest national daily newspaper, THE TIMES OF LONDON/

Newspaper

\section{(Germany)}

\section{TIMES/SUNDAY TIMES (LONDON) \\ June 1988-}

Worldwide literature on animal and human toxicity studies, effects of environmental chemicals and pollutants, adverse drug reactions, etc./

Journals, reports
Times Newspapers, Ltd. (U.K.)

L
TOXLINE

1965-
National Library of Medicine

DS, L, STN
TOXICITY BIBLIOGRAPHY; PESTICIDES ABSTRACTS; CHEMICAL-BIOLOGICAL ACTIVITIES; etc. 
TRADE AND INDUSTRY DATA.BASE $1981-$
Some full text of trade, industry, and commerce related information/

Journals, newspapers, books, reports
Information Access Company

DS, L
Journals, newspapers, books, reports

$\begin{array}{ll}\text { TRADELINE AND TRADELINE } & \text { Provides current and historical } \\ \text { INTERNATIONAL } & \text { security pricing, dividend, } \\ \text { Coverage varies } & \text { capitalization and descriptive } \\ & \text { information for over } 145,000 \\ & \text { United States and Canadian } \\ & \text { securities, over } 30,000 \text { inter- } \\ & \text { national securities and over } \\ & 1,600 \text { market indices/ }\end{array}$

Financial data

L

\begin{tabular}{|c|c|c|c|}
\hline \multirow{2}{*}{$\begin{array}{l}\text { TRADEMARKSCAN AUSTRIA } \\
\text { Current (active) } \\
\text { 1989- (inactive) }\end{array}$} & $\begin{array}{l}\text { Trademark registrations filed with } \\
\text { Oesterreichisches Patentamt }\end{array}$ & Compu-Mark N.V. (Belgium) & $\mathrm{L}$ \\
\hline & Trademarks & - & \\
\hline \multirow{2}{*}{$\begin{array}{l}\text { TRADEMARKSCAN BENELUX } \\
\text { Current (active) } \\
1989 \text { - (inactive) }\end{array}$} & $\begin{array}{l}\text { Trademark registrations filed with } \\
\text { Benelux-Merkenbureau/ }\end{array}$ & Compu-Mark N.V. (Belgium) & $\mathrm{L}$ \\
\hline & Trademarks & - & \\
\hline \multirow[t]{2}{*}{$\begin{array}{l}\text { TRADEMARKSCAN CANADA } \\
\text { Current (active) } \\
1978 \text { - (inactive) }\end{array}$} & $\begin{array}{l}\text { Information on trademark } \\
\text { registrations and applications } \\
\text { in Canada/ }\end{array}$ & Compu-Mark N.V. (Belgium) & $\mathrm{L}$ \\
\hline & Trademarks & - & \\
\hline \multirow[t]{2}{*}{$\begin{array}{l}\text { TRADEMARKSCAN DENMARK } \\
\text { Current (active) } \\
\text { 1992- (inactive) }\end{array}$} & $\begin{array}{l}\text { Trademark applications and } \\
\text { registrations filed with } \\
\text { Patentdirektoratet }\end{array}$ & Compu-Mark N.V. (Belgium) & $\mathrm{L}$ \\
\hline & Trademarks & - & \\
\hline \multirow[t]{2}{*}{$\begin{array}{l}\text { TRADEMARKSCAN-EUROPEAN } \\
\text { COMMUNITY } \\
\text { April 1996- }\end{array}$} & $\begin{array}{l}\text { Information on all active } \\
\text { applications and registrations } \\
\text { filed with the trademark } \\
\text { registry/ }\end{array}$ & Compu-Mark N.V. (Belgium) & $\mathrm{L}$ \\
\hline & Trademarks & - & \\
\hline
\end{tabular}




\section{TRADEMARKSCAN FRANCE}

Current (active)

1989- (inactive)
Trademark applications and registrations filed with Institut

National de la Propriete Industrielle/

Trademarks
Compu-Mark N.V. (Belgium)

$\mathbf{L}$
Trademark applications and registrations filed with

Deutsches Patenamt/
Compu-Mark N.V. (Belgium)

L

\section{Current (active)}

1989- (inactive)

Trademarks

TRADEMARKSCAN INTER-

\section{NATIONAL REGISTER}

Current (active)

1989- (inactive)
Trademark applications and registrations filed with the

World Intellectual Property Organization (WIPO)/

Trademarks
Compu-Mark N.V. (Belgium)

L
Trademark applications and registrations filed with the Ufficio Italiano Brevetti e Marchi/

Trademarks
Compu-Mark N.V. (Belgium)

L

\section{Current (active)}

1989- (inactive)
Trademarks filed with Amt für Volkswirtschaft Geistiges Eigentum/
Compu-Mark N.V. (Belgium)

L

\section{TRADEMARK
Current (active)}

1989- (inactive)

Trademarks

Trademarks filed with Propriété Industrielle Littéraire et Artistique/
Compu-Mark N.V. (Belgium)

L

TRADEMARKSCAN MONACO

Current (active)

1989- (inactive)

Trademarks

Trademark applications and registrations filed with Bundesamt für

\section{Current (active)}

1989- (inactive) geistiges Eigentam/

Trademarks
TRADEMARKSCAN-U.K.

Current (active)

1989- (inactive)
British trademarks and service marks/
Compu-Mark N.V. (Belgium)

L 
TRADEMARKSCAN-U.S. FEDERAL

Current (active)

1984- (inactive)
Information on all active registered and pending trademarks on file at the U.S. Patent and Trademark Office/
Thomson and Thomson

L

Trademarks

Company and product information for trademarks registered in the states and Puerto Rico/

Trademarks
TRADEMARK
Current (active)
1986- (inactive)
Comprehensive source of the world's official government import and export figures/

Trade statistics
Thomson and Thomson

L
TRADSTAT

Current
Numeric file containing evaluated thermodynamic data on 7,000 compounds/

Thermodynamic data

Worldwide literature of tribology/

Journals, books, standards, reports, proceedings, thesis, non-conventional literature
Thermodynamic Research Center, Texas A\&M University

Tradstat, Ltd. (U.K.)

DS
France's leading business daily/

Newspaper

\section{TRC THERMODYNAMIC TABLES}

Bundesanstalt für Materialforschung STN und -pruefung (Germany)
STN

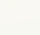

\section{TRIBO (TRIBOLOGY INDEX)
1972- \\ TRCTHERMO \\ Current}

LA TRIBUNE DB 1995-
Comprehensive information on highway, maritime, railroad, and air transportation/

Journals, ongoing research projects, reports
La Tribune Desfosses (France)

DS
TRIS (TRANSPORTATION RESEARCH INFORMATION SERVICES) 1968-
U.S. Department of Transportation, L Transportation Research Board NAS/NRC

HRIS ABSTRACTS; MRIS ABSTRACTS 
TRW BUSINESS CREDIT PROFILES

Current
Contains the payment history, bankruptcy, tax and legal history, UCC filings and banking relationships for over 2,500,000 companies/

Credit profiles

Experian

L

U.S. Environmental Protection

L

Compilation of chemical substances manufactured, imported

Chemical substances

\section{purposes in the United States/} or processed for commercial

Agency (EPA)

\section{9-}

TOXIC SUBSTANCES CONTROL ACT (TSCA) CHEMICAL SUBSTANCE INVENTORY
TULSA-PETROLEUM ABSTR.ACTS 1965-
Limited access (two hours/year) file to the worldwide petroleum literature/

Patents, journals, reports

The Food and Drug Administration's rules and regulations/

Rules, regulations
PETROLEUM ABSTRACTS

L, STN

PETROLEUM ABSTRACTS
21 CFR ONLINE

Current
DIOGENES

DS

CODE OF FEDERAL REGULATIONS
TV \& RADIO TRANSCRIPTS

DAILY

Current
Verbatim transcripts of programming from $\mathrm{ABC}$ news, MSNBC desktop video and national public radio/
Federal Document Clearing House

L

Transcripts

Environmental research database on current and completed research and development projects in Austria, Switzerland and Germany/

Research projects

Comprehensive directory of the Tradstat, Ltd. (U.K.)

DS

\section{4} names and addresses of importers of specific products into the United Kingdom/

Directory information 
DATABASE AVD DATES

COVERED
DESCRIPTION/

PRINCIPAL SOURCES
PRODUCER AND

HARD COPY COUNTERPART
VENDOR AND/OR

DATABASE INQUIRIES
UKRAINIAN COMPANIES

Current
Directory of manufacturing companies registered in the Ukraine/
BELSI Information Agency of

Concern "Spark" (Ukraine)
DS

Directory information

\section{ULIDAT}

1976-

Bibliographic database in German

Umweltbundesamt (Germany)

DS, STN

dealing with environmental

problems of German speaking

countries/

Journals, reports, monographs

Worldwide information on

periodicals, serials, annuals, etc./

R. R. Bowker

L

ULRICH'S INTERNATIONAL PERIODICALS DIRECTORY

Current
Periodicals
ULRICH'S INTERNATIONAL

PERIODICALS DIRECTORY;

IRREGULAR SERIALS AND

ANNUALS
UMU/DATATIMES

Current
Full text international business and financial news/

Reports, newspapers, magazines, newsletters
UMI/DataTimes $\quad$ DA, FI
Index to periodicals provided by contributing libraries worldwide/

Periodicals
The UnCover Company

L, NVL

September 1988-

Information on pharmacologically active substances and products that were in active development but were not listed in any standard reference work/

Manufacturer information

Full text of news stories carried on the United Press International wirel
Pharmaco Medical Documentation, DS, L Incorporated
UNLISTE
$1984-$

UPI NEWS

April 1983-

News items

\section{UNLISTED DRUGS}

United Press International,

L Incorporated

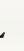

, FI

\begin{tabular}{|c|c|c|c|}
\hline $\begin{array}{l}\text { UNCOVER } \\
\text { September 1988- }\end{array}$ & $\begin{array}{l}\text { Index to periodicals provided by } \\
\text { contributing libraries worldwide/ } \\
\text { Periodicals }\end{array}$ & The UnCover Company & L, NVL \\
\hline $\begin{array}{l}\text { UNLISTED DRUGS } \\
\text { 1984 }\end{array}$ & $\begin{array}{l}\text { Information on pharmacologically } \\
\text { active substances and products } \\
\text { that were in active development } \\
\text { but were not listed in any } \\
\text { standard reference work/ } \\
\text { Manufacturer information }\end{array}$ & UNLISTED DRUGS & DS, L \\
\hline $\begin{array}{l}\text { UPI NEWS } \\
\text { April 1983- }\end{array}$ & $\begin{array}{l}\text { Full text of news stories carried } \\
\text { on the United Press International } \\
\text { wire/ } \\
\text { News items }\end{array}$ & $\begin{array}{l}\text { United Press International, } \\
\text { Incorporated }\end{array}$ & L \\
\hline
\end{tabular}




\section{U.S. COPYRIGHTS}

1978-
Registration details for all active copyright and mask-work registrations on file at the U.S. copyright office/
The Dialog Corporation;

U.S. Copyright Office
L

\section{Copyright data}

\section{U.S. PATENTS FULLTEXT} 1971-
Complete text of U.S. patents issued by the U.S. Patent and Trademark Office/

Patents
U.S. Patent and Trademark Office

L, STN

Literature on all aspects of the environment and related issues/

Umweltbundesamt (Germany)

DS 1976-

Journals, reports, monographs, grey literature

\section{UMWELTRECHTS-DATENBANK- ENVIRONMENTAL LAW Current \\ All aspects of environmental law in Germany and the European \\ Union/ \\ Legislation}

Umweltbundesamt (Germany)

DS
The U.S. Pharmacopeial

Convention, Incorporated
STN
1953-

Drug data
USP DI VOLUME 1, DRUG Current
Medically accepted uses for products/ generic and brand name drug

The United States Pharmacopeia

L

Monographs
USP DICTIONARY OF USAN AND INTERNATIONAL DRUG NAMES

Current
Authoritative drug dictionary/

U.S. Pharmacopeia
$\mathbf{L}$
Drug names
VADEMECUM

Current
Information in German on teaching and research institutions in Germany/

Directory information
Raabe Verlag; FIZ Karlsruhe STN
(Germany)

VADEMECUM DEUTSCHER LEHRUND FORSCHUNGSSTAETTEN 


\section{VTB (VERFAHRENSTECHNISCHE} BERICHTE)

1966-
Worldwide literature on chemical engineering in Germany/
BASF AG; Bayer AG (Germany)

STN

Journals, reports, books

Abstracts of articles published in the Eastern 3-star edition of THE WALL STREET JOURNAL

THE WALL STREET JOURNAL
New York Times

DS, L

\section{ABSTRACTS}

WALL STREET JOURNAL

$1973-$
Index to publications of the American Water Works Association and AWWA Research Foundation/

Reports, proceedings, books, journals
American Water Works Association

L
Information on ownership of 10,400 companies located in Germany/

Company information

\section{WER GEHÖRT ZU WEM}

Current
Listing of mechanical engineering products manufactured and offered for sale by about 4,400 companies in Germany/
Hoppenstedt Wirtschaftsverlag GmbH (Germany)
DS

\section{WHO MAKES MACHINERY \\ AND PLANT \\ Current}

JOURNAL AWWA

Commerzbank AG (Germany)

$-$

\section{WHO OWNS WHOM}

Current
International company ownership/

Company information
Dun \& Bradst reet, Ltd. (U.K.)

DS

\begin{tabular}{lll} 
& Company information & \\
$\begin{array}{l}\text { WHO SUPPLIES WHAT } \\
\text { Current }\end{array}$ & $\begin{array}{l}\text { Information on } 51,000 \text { German } \\
\text { companies and their products/ }\end{array}$ & $\begin{array}{l}\text { Bezugsquellennachweis für den } \\
\text { Einkauf "Wer liefert was?" } \\
\text { GmbH (Germany) }\end{array}$ \\
& - & \\
\hline
\end{tabular}

\section{WHO SUPPLIES WHAT}

Current
Information on 51,000 German

Einkauf "Wer liefert was?"

GmbH (Germany) 
WHO'S WHO EDITION EUROPEAN BUSINESS AND INDUSTRY

Current
Biographical information about managers in Europe's 7,000 largest companies/

Personal interviews
WHO'S WHO Edition GmbH

(Germany)
DS
Literature on engineering, aeronautics, chemistry, computer technology, earth sciences, energy and environment, mathematics, metallurgy, and physics/

Periodicals
H. W. Wilson Company

FI, L
AND TECHNOLOGY INDEX 1983-
International biological and

agricultural literature/

Journals, book reviews, chapters in annual reviews

Full text of general business periodicals and trade journals/

FULL TEXT

July 1982-

\begin{abstract}
WILSON BIOLOGICAL \& AGRICULTURAL INDEX 1983-
\end{abstract}

\section{APPLIED SCIENCE AND} TECHNOLOGY INDEX
H. W. Wilson Company

FI, L

Journals

BUSINESS PERIODICALS INDEX

BIOLOGICAL \& AGRICULTURAL INDEX

H. W. Wilson Company

$\mathrm{L}$

Literature covering all aspects of the contemporary business world/

Periodicals
H. W. Wilson Company

FI
INDEX

1983-
BUSINESS PERIODICALS INDEX

\section{WILSON GENERAL SCIENCE} INDEX/FULLTEXT

1984
Literature in the physical, life, and health sciences/
H. W. Wilson Company

FI, L
Periodicals

Index to the popular periodical literature/

Periodicals 
International literature of the social sciences/

H. W. Wilson Company

L
WILSON SOCIAL SCIENCES

ABSTRACTS

$1983-$
Periodicals

Single source of information on arts and entertainment, U.S. cities and states, people in the news, nations of the world, sports, the environment, vital statistics, science and technology, computers, taxes, etc.

\section{SOCIAL SCIENCES INDEX}

K-III Reference Corporation

FI

WORLD ALMANAC AND

BOOK OF FACTS 1996

Comprehensive global news from The Dialog Corporation three of the world's leading

information companies/

Newspapers, magazines, newswires

\section{WORLD REPORTER}

May 1997-
World literature of textiles and

the textile industry/

Journals, patents, standards, books, reports
Elsevier Science B.V. (U.K.)

L
WORLD TEXTILES

1970
Translations of the literature from all languages in all fields of science and technology/

Translations

Listing of books and other materials in libraries worldwide/

Books, journals, audiovisuals, newspapers, maps
WORLD TEXTILE ABSTRACTS

ITC (Netherlands); CNRS (France)

L
WORLDCAT

1000
WORLD TRANSLATIONS INDEX 1979-
Financial reports on companies worldwide/

Reports, newspapers, wire services
W/D Partners

FI

\section{WORLDSCOPE}

Current 
WORLDWIDE TAX DAILY 1987-
Worldwide tax news and developments/

Press releases, rulings, court opinions, treaties, agreements, congressional materials
Tax Analysts

L
Derwent Information, Ltd. (U.K.)
L, STN

Comprehensive international information relating to patents and patent specifications/

Patents

CENTRAL PATENTS INDEX; WORLD PATENTS INDEX
WRA (WATER RESOURCES ABSTRACTS)

1968-
Literature on water-related aspects of the life, physical, and social sciences/

Monographs, journals, reports
Cambridge Scientific Abstracts

L

\section{SELECTED WATER RESOURCES ABSTRACTS}

\section{XNHUA NEWS}

July 1996-
News from the People's Republic of Chinal
Comtex Scientific Corporation

L

News

Directories of the officers and management of major U.S. corporations and financial

institutions/
Directory information
Leadership Directories, Incorporated

L

\section{AND FINANCIAL}

Current
YELLOW BOOK: CORPORATE YELLOW BOOK: FINANCIAL
YELLOW BOOKS: LAW FIRMS Current
Directory of the largest U.S. law firms/

Directory information

Library catalog of holdings of periodical scientific literature for about 3500 German libraries/

Journals, serials, newspapers, proceedings
Leadership Directories, Incorporated

L

YELLOW BOOKS: LAW FIRMS

Deutsches Bibliothekinstitut
16 th century-
(Germany) 
DATABASE AND DATES

COVERED

ZOOLOGICAL RECORD ONLINE

1978-
DESCRIPTION/

PRINCIPAL SOURCES

Coverage of the world's zoologi-

cal literature with emphasis on

systematic/taxonomic information/

Serials, theses, proceedings, journals
PRODUCER AND

HARD COPY COUNTERPART

VENDOR AND/OR

DATABASE INQUIRIES

BIOSIS

L

ZOOLOGICAL RECORD 
The NIST Research Library subscribes to a variety of databases on CD-ROM. You may use these databases without charge.

CD-ROM/ YEARS COVERED

ANALYTICAL ABSTRACTS

1980
DESCRIPTION

Royal Society of Chemistry's

comprehensive literature on

analytical chemistry

Worldwide biotechnology

literature
HARD COPY

EQUIVALENT

ANALYTICAL ABSTRACTS

BIOTECHNOLOGY CITATION

INDEX
1994

CA (CHEMICAL ABSTRACTS)

12TH COLLECTIVE INDEX

1987-1991

COMPACT CAMBRIDGE LIFE

SCIENCES

1986-1994
Index to worldwide chemical and chemical engineering literature
CHEMICAL ABSTRACTS

COLLECTIVE INDEX

1987-1991
COMPUTER SELECT

Current 12 months
Literature of the life sciences, including the biological, medical and agricultural sciences
19 abstract journals published by

Cambridge Scientific Abstracts
Full text of computer magazines covering computer technology, industry, and consumer news
Various computer periodicals
INSPEC ONDISC

1992-
World's literature on physics, electronics and computing
PHYSICS ABSTRACTS;

ELECTRICAL AND

ELECTRONIC ABSTRACTS; COMPUTER AND CONTROL ABSTRACTS; INFORMATION TECHNOLOGY

Worldwide literature of materials science and engineering
MATERIALS SCIENCE CITATION INDEX
MATER
INDEX

1994

\footnotetext{
*Limited to NIST Staff use
} 
CD-ROM/

YEARS COVERED

MATHSCI DISC

1980-
DESCRIPTION

Worldwide mathematical literature

companies

U.S. Government-sponsored

research and development

prepared by federal agencies,

their contractors and grantees

Material Safety Data Sheets

(MSDS) for hazardous/toxic

substances
HARD COPY

EQUIVALENT

MATHEMATICAL REVIEWS; CURRENT MATHEMATICAL PUBLICATIONS

MOODY'S COMPANY DATA

REPORTS

GOVERNMENT REPORTS

ANNOUNCEMENTS AND

INDEX
OHS MSDS ON DISC

Current
Worldwide scientific and technical literature
MATERIAL SAFETY DATA

SHEETS
SCIENCE CITATION INDEX

COMPACT DISC

1985-
SCIENCE CITATION INDEX 
Aerospace and Aeronautical Engineering

Agriculture and Agricultural Engineering

Architecture and Design

Arts and Humanities
-AEROSPACE DATABASE
COMPENDEX
DELURA
FLIGHTLINE
IAC AEROSPACE/DEFENSE MARKETS \& TECHNOLOGY INSPEC

JANE'S DEFENSE AND AEROSPACE NEWS/ANALYSIS NTIS

SAE AUTOMOTIVE STANDARDS

SAE GLOBAL MOBILITY

SCISEARCH

-AGRICOLA

AGRIS INTERNATIONAL

BIOSIS PREVIEWS

CAB ABSTRACTS

CHEMICAL ABSTRACTS

COMPENDEX

CRIS/USDA

DERWENT CROP PROTECTION FILE

ENERGY SCIENCE AND TECHNOLOGY

FOOD SCIENCE AND TECHNOLOGY ABSTRACTS

FOODLINE

FOODLINE: CURRENT FOOD LEGISLATION

FOODLINE: INTERNATIONAL FOOD MARKET DATA

FOODS ADLIBRA

MAGAZINE INDEX

NTIS

PAPERCHEM

PESTICIDE FACT FILE

PESTLINE

POLLUTION ABSTRACTS

SCISEARCH

WATERNET

WILSON BIOLOGICAL \& AGRICULTURAL INDEX

WRA

-ARCHITECTURE DATABASE

ARTBIBLIOGRAPHIES MODERN

COMPENDEX

ENERGY SCIENCE AND TECHNOLOGY

SOCIAL SCISEARCH

-ART LITERATURE INTERNATIONAL ARTBIBLIOGRAPHIES MODERN ARTS AND HUMANITIES SEARCH BIBLIOGRAPHY OF THE HISTORY OF ART CAB ABSTRACTS

HUMANITIES ABSTRACTS FULL TEXT

MAGAZINE INDEX

MAGILL'S SURVEY OF CINEMA 
Audiovisual Media

Awards

Bioengineering/Biotechnology

Biography

Biology

See: Life Sciences, Medicine

Buildings

Business, Economics, Management
-A-V ONLINE

-AWARDS DATABASE

-AGRIBUSINESS U.S.A.

BIOCOMMERCE ABSTRACTS AND DIRECTORY BIOSIS PREVIEWS

BIOTECHNOLOGY ABSTRACTS

BIOTECHNOLOGY CITATION INDEX

CAMBRIDGE SCIENTIFIC ABSTRACTS LIFE SCIENCE

CEBA

CHEMICAL ENGINEERING AND BIOTECHNOLOGY ABSTRACTS COMPENDEX

CURRENT BIOTECHNOLOGY ABSTRACTS

DIALOG SOURCEONE: ENGINEERING

EMBASE

FINANCIAL TIMES BUSINESS REPORTS INDUSTRY

INSPEC

MEDICONF

MEDITEC: BIOMEDICAL ENGINEERING

MEDLINE

-BIOGRAPHY INDEX

BIOGRAPHY MASTER INDEX

BOWKER BIOGRAPHICAL DIRECTORY

MARQUIS WHO'S WHO

STANDARD AND POOR'S REGISTER-BIOGRAPHICAL WHO'S WHO EDITION EUROPEAN BUSINESS AND INDUSTRY

- COMPENDEX

ENERGY SCIENCE AND TECHNOLOGY

FEDERAL RESEARCH IN PROGRESS

ICONDA

NTIS

RSWB

-ABC EUROPE

ABU/INFORM

ACCESS CZECH REPUBLIC BUSINESS BULLETIN

ACCESS DISCLOSURE INDEX

ACCOUNTING \& TAX DATABASE

ADVERTISE

ADVERTISER \& AGENCY RED BOOKS: ADVERTISERS

ADVERTISER \& AGENCY RED BOOKS: AGENCIES

AMERICAN BANKER

AMERICAN BANKER NEWS

AMERICAN BUSINESS DIRECTORY

API ENCOMPASS: NEWS

ASIA INTELLIGENCE WIRE 


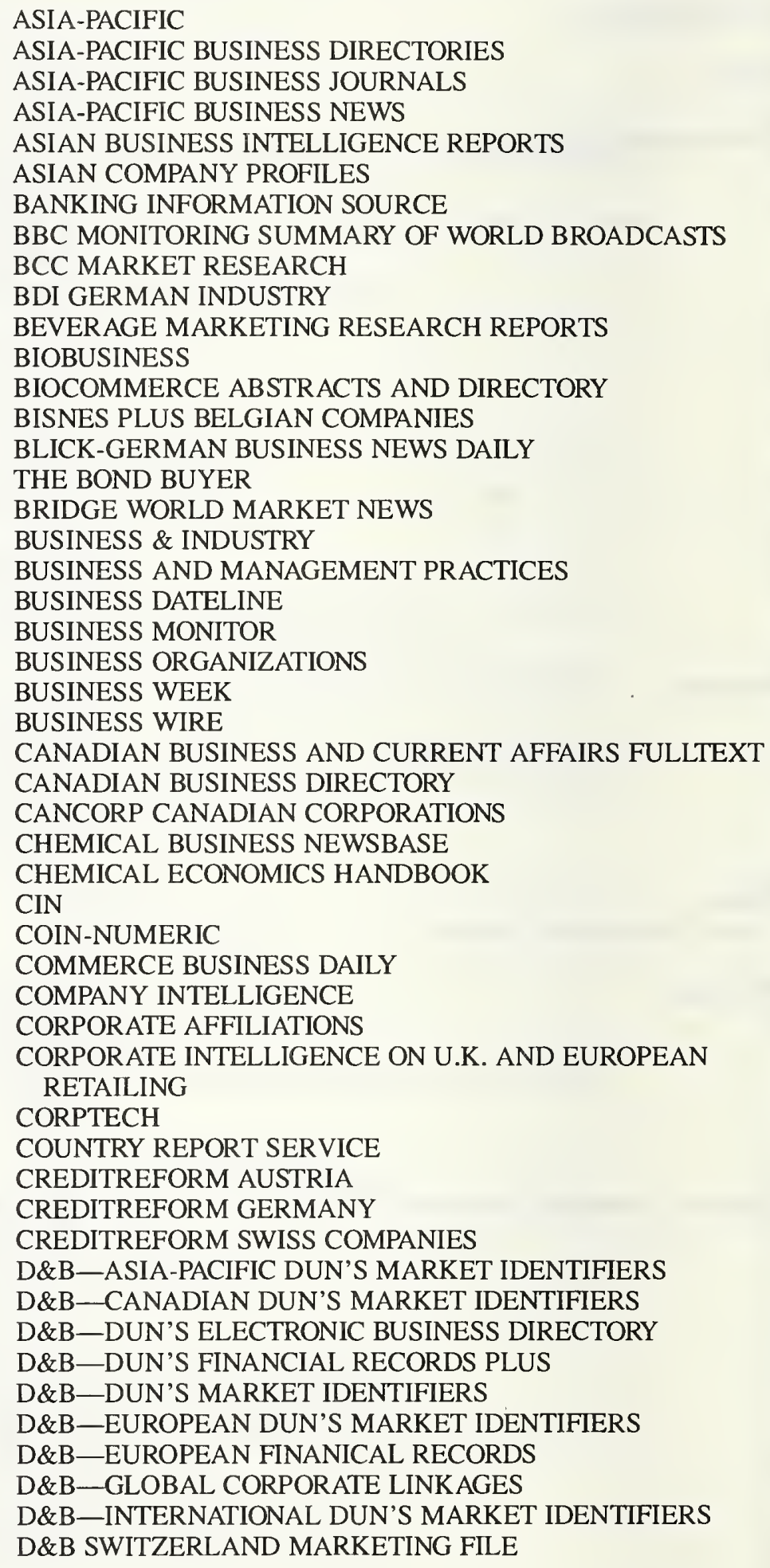




\section{GENERAL SUBJECT INDEX}

DANISH COMPANIES: FULL FINANCIAL DATA

DATAMONITOR MARKET REPORTS

DELPHES EUROPEAN BUSINESS

DIALOG/MONEYCENTER

DIALOG QUOTES AND TRADING

DIRECTORY OF POLISH COMPANIES

DISCLOSURE

DISCLOSURE/SPECTRUM OWNERSHIP

DM HUSET NORWEGIAN COMPANIES

DMS/FI MARKET INTELLIGENCE REPORTS

DOW JONES NEWS/RETRIEVAL

DRTE

DUN \& BRADSTREET AUSTRIA

DUN \& BRADSTREET BELGIUM

DUN \& BRADSTREET DENMARK

DUN \& BRADSTREET EASTERN EUROPE

DUN \& BRADSTREET FRANCE

DUN \& BRADSTREET GERMANY

DUN \& BRADSTREET GREECE

DUN \& BRADSTREET IRELAND

DUN \& BRADSTREET ISRAEL

DUN \& BRADSTREET ITALY

DUN \& BRADSTREET JAPAN

DUN \& BRADSTREET LUXEMBOURG

DUN \& BRADSTREET MIDDLE EAST, AFRICA, AND LATIN

AMERICA

DUN \& BRADSTREET NETHERLANDS

DUN \& BRADSTREET PORTUGAL

DUN \& BRADSTREET SPAIN

DUN \& BRADSTREET SWISS COMPANIES FULL FINANCIAL

DATA

DUN \& BRADSTREET UNITED KINGDOM

EBIS-EMPLOYEE BENEFITS INFOSOURCE

ECONBASE: TIME SERIES AND FORECASTS

ECONOMIC LITERATURE INDEX

ECONOVO

ECOREGISTER

EDGARPLUS

EIU: BUSINESS INTERNATIONAL

EIU: BUSINESS NEWSLETTERS

EIU: COUNTRY ANALYSIS

EIU: COUNTRY RISK AND FORECASTS

EIU: VIEWS WIRE

ESPICOM TELECOMMUNICATIONS/POWER REPORTS

EURO-SELECT

EUROMONEY PUBLICATIONS

EUROMONITOR JOURNALS

EUROMONITOR MARKET DIRECTION

EUROMONITOR MARKET REPORTS

EUROPEX

EXTEL INTERNATIONAL FINANCIAL CARDS

EXTEL INTERNATIONAL NEWS CARDS 
FAKT

FBR ASIAN COMPANY PROFILES

FINANCIAL TIMES BUSINESS REPORTS EASTERN EUROPE

DATABASE

FINANCIAL TIMES BUSINESS REPORTS ENERGY AND ENVIRONMENT

FINANCIAL TIMES BUSINESS REPORTS FINANCIAL

MANAGEMENT AND INSURANCE

FINANCIAL TIMES BUSINESS REPORTS INDUSTRY

FINANCIAL TIMES BUSINESS REPORTS TECHNOLOGY

FINANCIAL TIMES FULLTEXT

DE FINANCIEEL EKONOMISCHE TIJD

FIND/SVP MARKET RESEARCH REPORTS

FINDEX

FIRMIMPORT/FIRMEXPORT

FOODLINE: INTERNATIONAL FOOD MARKET DATA

FOODS ADLIBRA

FOUNDATION DIRECTORY

FOUNDATION GRANTS INDEX

FREEDONIA MARKET RESEARCH

FRENCH COMPANIES-FULL FINANCIAL INFORMATION

FROST \& SULLIVAN MARKET RESEARCH

FUJI-KEIZAI MARKET RESEARCH

THE GERMAN INDUSTRY

GLOBALBASE

GRANTS

HARVARD BUSINESS REVIEW/ONLINE

HOPPENSTEDT AUSTRIA

HOPPENSTEDT BENELUX

HOPPENSTEDT DIRECTORY OF GERMAN COMPANIES

HSELINE

IAC AEROSPACE/DEFENSE MARKETS \& TECHNOLOGY

IAC BUSINESS A.R.T.S.

IAC F\&S INDEX

IAC GLOBALBASE

IAC INDUSTRY EXPRESS

IAC MARKETING AND ADVERTISING REFERENCE SERVICE

IAC NEW PRODUCT ANNOUNCEMENTS

IAC NEWSEARCH

IAC NEWSLETTER DATABASE

IAC PHARMABIOMED BUSINESS JOURNALS

IAC PROMPT

ICC BRITISH COMPANY ANNUAL REPORTS

ICC BRITISH COMPANY DIRECTORY

ICC BRITISH COMPANY FINANCIAL DATASHEETS

ICC INTERNATIONAL BUSINESS RESEARCH

ICC KEY NOTE MARKET ANALYSIS

ICC STOCKBROKER RESEARCH

IMSWORLD PHARMACEUTICAL COMPANY PROFILES

INDUSTRY TRENDS AND ANALYSIS

INFO LATINO AMERICA 


\section{GENERAL SUBJECT INDEX}

INFOCHECK UK COMPANY FINANCIAL DATASHEETS
INFOTRADE BELGIUM COMPANY DATABASE
INITIAL PUBLIC OFFERINGS
INTERNATIONAL BUSINESS DIRECTORY INTERNATIONAL BUSINESS OPPORTUNITIES SERVICES INTERNATIONAL MARKET RESEARCH INFORMATION INTERNATIONAL RISK AND PAYMENT REVIEW INVESTEXT

IRISH BUSINESS INFORMATION

ITALIAN COMPANY PROFILES

JAPAN ECONOMIC NEWSWIRE PLUS

JAPAN NEWS WIRE

JERUSALEM POST ELECTRONIC EDITION

JORDANWATCH

JOURNAL OF COMMERCE

JUPITER MARKET RESEARCH

KEY BRITISH ENTERPRISES FINANCIAL PERFORMANCE KOMPASS ASIA/PACIFIC

KOMPASS CANADA

KOMPASS EASTERN EUROPE

KOMPASS EUROPE

KOMPASS MIDDLE EAST/AFRICA/MEDITERRANEAN

KOMPASS UK

KOMPASS USA

KR FINANCE AND BANKING NEWSLETTERS

KREDITFAKTA COMPANY FINANCIAL DATABASE

KREDITSCHUTZVERBAND: AUSTRIAN COMPANIES

LAFFERTY BANKING, INSURANCE, AND PROFESSIONAL SERVICES INTELLIGENCE

M\&A FILINGS

MCGRAW-HILL PUBLICATIONS ONLINE

MAGAZINE INDEX

MANAGEMENT AND MARKETING ABSTRACTS

MANAGEMENT CONTENTS

MANAGEMENT INFOWIRTSCHAFT

MARKET \& BUSINESS DEVELOPMENT

MARKET STRUCTURE AND TRENDS IN ITALY

MARKETLINE MARKET REPORTS

MARKETSEARCH: INTERNATIONAL DIRECTORY OF

PUBLISHED MARKET RESEARCH

MG FINANCIAL/STOCK STATISTICS

MILLER FREEMAN INDUSTRY AND PRODUCT NEWS

MONDO ECONOMICO, L'IMPRESA

MONEYCLIPS

MOODY'S COMPANY DATA

MOODY'S CORPORATE NEWS-INTERNATIONAL

MOODY'S CORPORATE NEWS-US

MOODY'S CORPORATE PROFILES

MSI REPORTS

NEW YORK TIMES

NIELSEN MARKET STATISTICS/CANADA 
THE OFFICIAL REGISTER OF CZECH AND SLOVAK ORGANIZATIONS

$1 \times 1$ GERMAN BUYERS' GUIDE

PAIS INTERNATIONAL

PHARMA MARKETING SERVICE

PHARMACONTACTS

PIERS IMPORTS

PIERS EXPORTS

PIERS EXPORTS (MEXICO)

PIRA

PNI

PROQUEST DIRECT

QUEST ECONOMICS DATABASE

REUTERS

RUSSIAN AND CIS NEWS

SCRL FRENCH COMPANIES FINANCIAL PROFILES

SDC WORLDWIDE MERGERS \& ACQUISITIONS

SDC'S JOINT VENTURES AND ALLIANCES

SDOE/ITIE

SEC ONLINE

SEIBT STANDARD PARTS

SEMA GROUP SWEDISH COMPANIES

SOCIAL SCISEARCH

SOCIETE GENERALE DE BANKE

SOFTBASE: REVIEWS, COMPANIES, AND PRODUCTS

SOLE

STANDARD AND POOR'S CORPORATE DESCRIPTIONS

STANDARD AND POOR'S CORPORATE DESCRIPTIONS PLUS NEWS

STANDARD AND POOR'S DAILY NEWS

SUMMARY OF PROPOSED PROJECTS

TECHNIMETRICS EXECUTIVE DIRECTORY

TECHNIMETRICS SHARE/WORLD

TEIKOKU DATABANK: JAPANESE COMPANIES

TELEFIRM

TENDERS ELECTRONIC DAILY

TEXTLINE GLOBAL NEWS

THOMAS REGISTER ONLINE

THOMSON/POLK BANKING DATABASE

TRADE AND INDUSTRY DATABASE

TRADE NAMES DATABASE

TRADELINE AND TRADELINE INTERNATIONAL

TRADSTAT

LA TRIBUNE DB

TRENDS, TENDANCES

TRW BUSINESS CREDIT PROFILES

UK IMPORTERS

UKRAINIAN COMPANIES

UMI/DATATIMES

WER GEHÖRT ZU WEM

WHO SUPPLIES WHAT

WHO OWNS WHOM 
Business, Economics, Management (cont.)

Chemistry and Chemical Engineering
WHO'S WHO EDITION EUROPEAN BUSINESS AND INDUSTRY WILSON BUSINESS ABSTRACTS FULLTEXT WILSON BUSINESS PERIODICALS INDEX WORLDSCOPE

YELLOW BOOKS: CORPORATE AND FINANCIAL

-AEROSPACE DATABASE AGRICOLA ALUMINUM ASSOCIATION STANDARDS AND DATA ALUMINUM FRACTURE TOUGHNESS DATABASE ALUMINUM INDUSTRY ABSTRACTS ANALYTICAL ABSTRACTS API ENCOMPASS: NEWS APILIT APIPAT ASFA ASMDATA

BEILSTEIN

CAPLUS

CASREACT

CEBA

CEN

CERAMIC ABSTRACTS

CHAPMAN AND HALL CHEMICAL DATABASE

CHEM SOURCES CHEMICAL DIRECTORY

CHEM SOURCES COMPANY DIRECTORY

CHEMCATS

CHEMICAL ABSTRACTS

CHEMICAL BUSINESS NEWSBASE

CHEMICAL ECONOMICS HANDBOOK

CHEMICAL ENGINEERING AND BIOTECHNOLOGY ABSTRACTS CHEMICAL SAFETY NEWSBASE

CHEMINFORMRX

CHEMLIST

CHEMNAME

CHEMPLANT PLUS

CHEMREACT

CHEMSAFE

CHEMSEARCH

CHEMSTATS

CHEMTOX ONLINE

CIN

CJACS

CJAOAC

CJELSEVIER

CJRSC

$\mathrm{CJVCH}$

CJWILEY

CLAIMS/COMPOUND REGISTRY

CLAIMS/UNITERM

COMPENDEX

COPPERDATA 


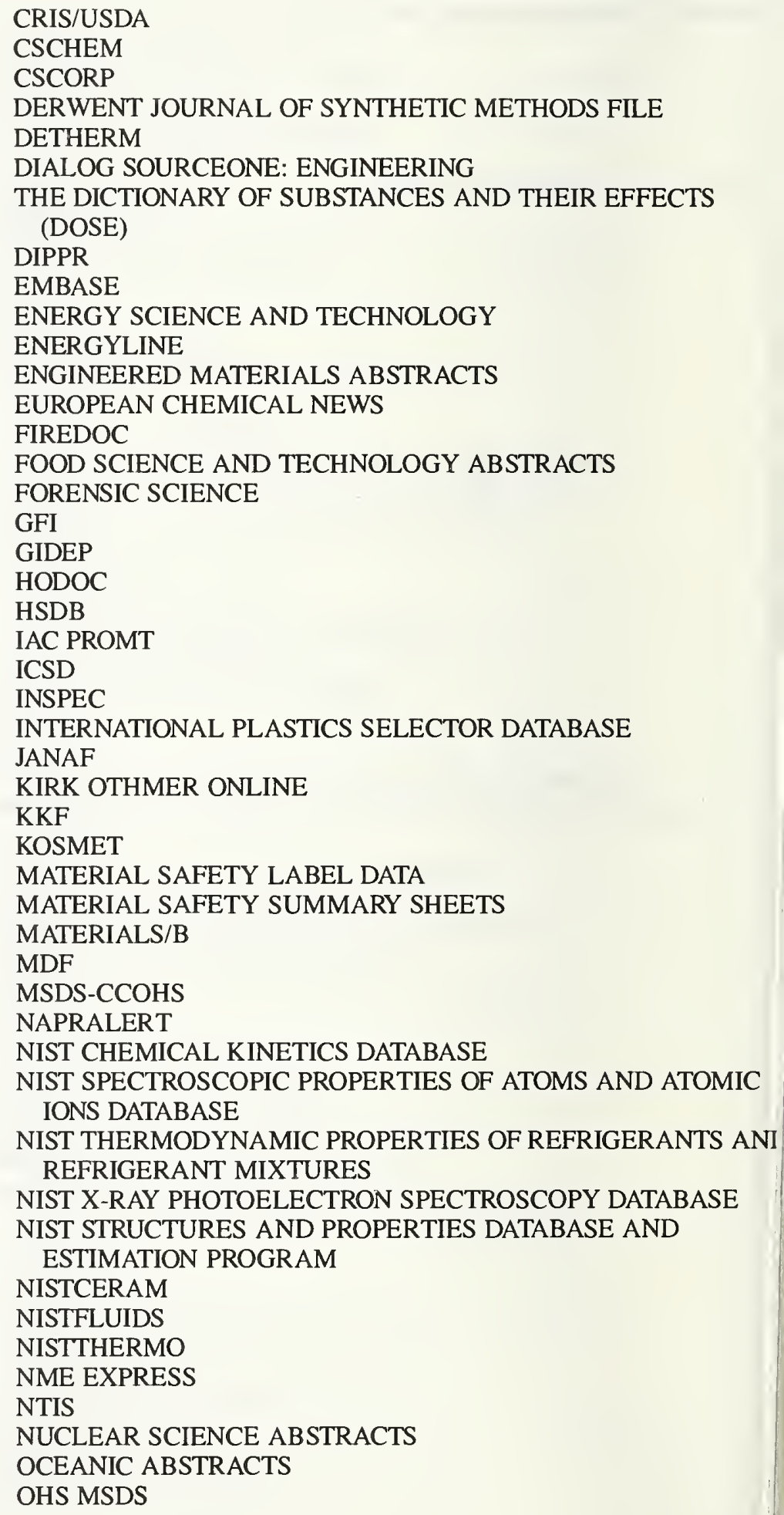


GENERAL SUBJECT INDEX

SUBJECT

Chemistry and Chemical Engineering (cont.)
DATABASE NAME

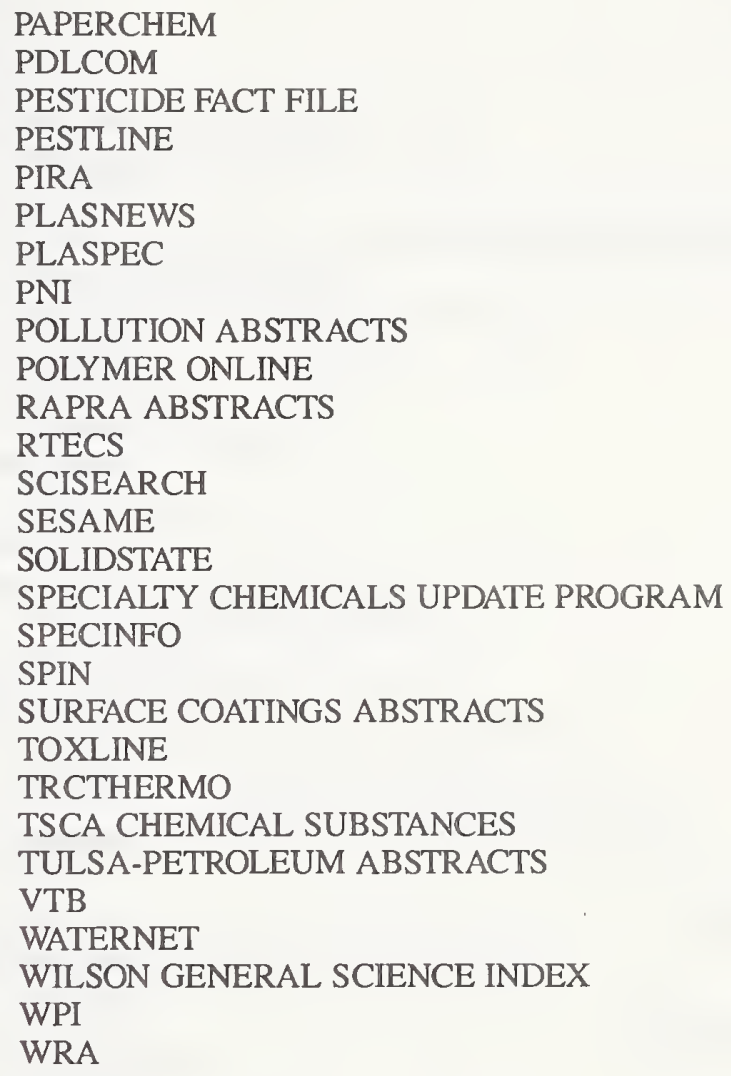


SUBJECT

Computer Science

Copyright

Cosmetics

Consumer Information

Current Research Projects

Earth and Space

See also: Aerospace and Aeronautical

Engineering Mining and Metallurgy
DATABASE NAME

-ABIINFORM
CMP COMPUTER FULLTEXT
COMPENDEX
COMPUAB
COMPUSCIENCE
THE COMPUTER DATABASE
COMPUTER NEWS FULLTEXT
COMPUTER SELECT
DATAPRO REPORTS AND ANALYSIS
FUJI-KEIZAI MARKET RESEARCH
IAC NEWSEARCH
INSPEC
ISIS SOFTWARE DATABASE
LISA
MICROCOMPUTER ABSTRACTS
MICROCOMPUTER SOFTWARE GUIDE
NTIS
SCISEARCH

SOFTBASE: REVIEWS, COMPANIES, AND PRODUCTS

—U.S. COPYRIGHTS

-KOSMET

- CONSUMER REPORTS

CONSUMERS INDEX

- CRIS/USDA

EPD

FEDERAL RESEARCH IN PROGRESS

FORIS

FORKAT

JAPANESE GOVERNMENT AND PUBLIC RESEARCH IN PROGRESS

SESAME

SUMMARY OF PROPOSED PROJECTS

TRIS

UFORDAT

-AEROSPACE DATABASE

ASFA

ENERGY SCIENCE AND TECHNOLOGY

GEOARCHIVE

GEOBASE

GEOREF

INSPEC

METEOROLOGICAL AND GEOASTROPHYSICAL ABSTRACTS OCEANIC ABSTRACTS

SCISEARCH

SPIN

WATERNET

WRA 


\section{GENERAL SUBJECT INDEX}

DATABASE NAME

Economics

See: Business, Economics, Management

Education

-BRITISH EDUCATION INDEX

EDUCATION INDEX

ERIC

LINGUISTICS AND LANGUAGE BEHAVIOR ABSTRACTS

PAIS INTERNATIONAL

PETERSON'S COLLEGE DATABASE

PETERSON'S GRADLINE

PSYCHINFO

SOCIAL SCISEARCH

SPORT

VADEMECUM

Electronics and Electrical Engineering

See also: Civil Engineering

Mechanical Engineering

-AEROSPACE DATABASE

CMP COMPUTER FULLTEXT

COMPENDEX

THE COMPUTER DATABASE

DIALOG SOURCEONE: ENGINEERING

ELCOM

ELECTRO/ELECTRONICS BUYERS' GUIDE

ENERGY SCIENCE AND TECHNOLOGY

EPD

GIDEP

IEEE/IEE PUBLICATIONS ONDISC

INSPEC

NTIS

SCISEARCH

SPIN

TRIS

Energy

-AEROSPACE INDEX

API ENCOMPASS: NEWS

CHEMICAL ABSTRACTS

ENERGIE

ENERGY SCIENCE AND TECHNOLOGY

ENERGYLINE

ENVIROLINE

ENVIRONMENTAL BIBLIOGRAPHY

EPD

FINANCIAL TIMES BUSINESS REPORTS ENERGY AND ENVIRONMENT

GEOARCHIVE

GEOREF

INSPEC

NTIS

PAIS INTERNATIONAL

PAPERCHEM

POLLUTION ABSTRACTS

SCISEARCH

SESAME 
Energy (cont.)

Engineering

See: Special Discipline of Engineering e.g., Civil Engineering, Mechanical Engineering, etc.

Environment

Food Science

See also: Agriculture and Agricultural Engineering
WATERNET

WPI

-AGRICOLA

ASFA

BIOSIS PREVIEWS

CHEMICAL ABSTRACTS

CHEMTOX ONLINE

COMPENDEX

CONFERENCE PAPERS INDEX

DHMT

EMBASE

ENERGY SCIENCE AND TECHNOLOGY

ENERGYLINE

ENVIROLINE

ENVIRONMENT

ENVIRONMENTAL BIBLIOGRAPHY

FINANCIAL TIMES BUSINESS REPORTS ENERGY AND ENVIRONMENT

GEOARCHIVE

GEOBASE

GEOREF

MAGAZINE INDEX

MEDLINE

METEOROLOGICAL AND GEOASTROPHYSICAL ABSTRACTS

NTIS

OCEANIC ABSTRACTS

PAPERCHEM

PDLCOM

POLLUTION ABSTRACTS

SCISEARCH

SOCIAL SCISEARCH

TRIS

UFORDAT

ULIDAT

UMWELTLITERATURDATENBANK

UMWELTRECHTS-DATENBANK-ENVIRONMENTAL LAW

WATERNET

WRA

-AGRICOLA

BIOSIS PREVIEWS

CHEMICAL ABSTRACTS

FOOD SCIENCE AND TECHNOLOGY ABSTRACTS

FOODLINE

FOODLINE: CURRENT FOOD LEGISLATION

FOODLINE: INTERNATIONAL FOOD MARKET DATA 


\section{GENERAL SUBJECT INDEX}

SUBJECT

Food Science (cont.)

Forensic Science

General Science and Technology/Miscellaneous
DATABASE NAME

FOODS ADLIBRA

PACKAGING SCIENCE AND TECHNOLOGY ABSTRACTS

SCISEARCH

-FORENSIC SCIENCE

-ABSTRACTS IN NEW TECHNOLOGIES AND ENGINEERING ARTICLEFIRST

ASI

BIBLIODATA

BOOK REVIEW DIGEST

BOOK REVIEW INDEX

BOOKS IN PRINT

BRANDS AND THEIR COMPANIES

BRITANNICA ONLINE

BRITISH BOOKS IN PRINT

CAMBRIDGE SCIENTIFIC ABSTRACTS

CLAIMS/PATENTS

CONF

CONFERENCE PAPERS INDEX

CONTENTSFIRST

CRSP

CURRENT CONTENTS SEARCH

D\&B DUN'S ELECTRONIC BUSINESS DIRECTORY

DIALOG SOURCEONE: ENGINEERING

DIRECTORY OF PUBLISHED PROCEEDINGS

DISSERTATION ABSTRACTS ONLINE

DMS/FI CONTRACT AWARDS

DROLS

EBSCO MAGAZINES

ENCYCLOPEDIA OF ASSOCIATIONS

EUROPEAN RESEARCH \& DEVELOPMENT DATABASE

EVENTLINE

FACTSEARCH

FHGPUBLICA

FI DEFENSE MARKET INTELLIGENCE REPORTS

FORKAT

FTN

GALE DATABASE OF PUBLICATIONS AND BROADCAST MEDIA

GALE DIRECTORY OF ONLINE, PORTABLE, AND INTERNET DATABASES

GENERAL PRACTITIONER

GENERAL SCIENCE ABSTRACTS/FULLTEXT

GIDEP

GPO MONTHLY CATALOG

GPO PUBLICATIONS REFERENCE FILE

INFOR

INSIDE CONFERENCES

ISTP

JANE'S DEFENSE AND AEROSPACE NEWS/ANALYSIS

JICST-EPLUS 
General Science and Technology/Miscellaneous (cont.)
KR DEFENSE NEWSLETTERS

LC MARC

M\&A TRADESHOW DATABASE

MCGRAW-HILL PUBLICATIONS ONLINE

MAGAZINE INDEX

MATERIALS SCIENCE CITATION INDEX

NATIONAL NEWSPAPER INDEX

NEW YORK TIMES

NTIS

OCLC

THE ONLINE CATALOG

PAPERSFIRST

PASCAL

PEDS: DEFENSE PROGRAM SUMMARIES

PERIODICAL ABSTRACTS PLUSTEXT

PROCEEDINGSFIRST

PUBLIC OPINION ONLINE

PUBLISHERS, DISTRIBUTORS AND WHOLESALERS

REMARC

RUSSIAN SCIENTIFIC NEWS DATABASE

RESEARCH CENTERS AND SERVICES DIRECTORY

SCISEARCH

SERIALS IN SWISS LIBRARIES

SIGLE

SIRS RESEARCHER

TAX NOTES TODAY

TECHNOLOGY ASSESSMENT

TIBKAT

TV \& RADIO TRANSCRIPTS DAILY

ULRICH'S INTERNATIONAL PERIODICALS DIRECTORY

UNCOVER

WILSON APPLIED SCIENCE AND TECHNOLOGY INDEX

WILSON GENERAL SCIENCE INDEX/FULLTEXT

WILSON READERS' GUIDE ABSTRACTS FULL TEXT

WORLD ALMANAC

WORLDCAT

WORLDWIDE TAX DAILY

ZDB (ZEITSCHRIFT DATENBANK)

Geology

See: Earth and Space Mining and Metallurgy

Government Reports

\author{
-AEROSPACE DATABASE \\ FIREDOC \\ GIDEP \\ GPO MONTHLY CATALOG \\ GPO PUBLICATIONS REFERENCE FILE \\ NTIS \\ OCCUPATIONAL SAFETY AND HEALTH \\ PAIS INTERNATIONAL \\ TRIS
}




\section{GENERAL SUBJECT INDEX}

SUBJECT

Grants

History

Information Science

Insurance

Internet Resources

Law and Legislative Processes
DATABASE NAME

-FOUNDATION DIRECTORY

FOUNDATION GRANTS INDEX

GRANTS

-AMERICA: HISTORY AND LIFE

ARTBIBLIOGRAPHIES MODERN

HISTLINE

HISTORICAL ABSTRACTS

-ABI/INFORM

AMERICAN LIBRARY DIRECTORY

COMPUAB

ERIC

INFODATA

INFORMATION SCIENCE ABSTRACTS

INSPEC

LIBRARY LITERATURE

LISA

NTIS

SCISEARCH

SOCIAL SCISEARCH

-FINANCIAL TIMES BUSINESS REPORTS FINANCIAL MANAGEMENT AND INSURANCE INSURANCE INFORMATION ONLINE INSURANCE PERIODICALS INDEX

-NETFIRST

-ABI/INFORM

CELEX

CONGRESSIONAL RECORD

COURT PETITIONS AND COMPLAINTS

CRIMINAL JUSTICE PERIODICAL INDEX

FEDERAL ACQUISITION REGULATIONS

FEDERAL NEWS SERVICE

FEDER AL REGISTER

IAC LEGAL RESOURCE INDEX

IAC NEWSEARCH

INDEX TO LEGAL PERIODICALS \& BOOKS

LEXIS

MANAGEMENT CONTENTS

NCJRS

PAIS INTERNATIONAL

RUSSIAN AND CIS NEWS

SOCIAL SCISEARCH

SPEARHEAD

SPICER'S CENTRE FOR EUROPE DATABASE

TAX NOTES TODAY

21CFR ONLINE

UMWELTRECHTS-DATENBANK-ENVIRONMENTAL LAW

WRA

YELLOW BOOKS: LAW FIRMS 
Life Sciences (cont.)Life Sciences See also: Medicine
Literature

Management

See: Business, Economics, Management

Materials Science
-AGRICOLA

ASFA

BIOBUSINESS

BIOCOMMERCE ABSTRACTS AND DIRECTORY

BIOLOGY DIGEST

BIOSIS PREVIEWS

CAB ABSTRACTS

CAMBRIDGE SCIENTIFIC ABSTRACTS LIFE SCIENCE

CANCERLINE

CATLINE

CHEMICAL ABSTRACTS

CONFERENCE PAPERS INDEX

CURRENT BIOTECHNOLOGY ABSTRACTS

DGENE

EMBASE

ENERGY SCIENCE AND TECHNOLOGY

ENVIRONMENTAL BIBLIOGRAPHY

GENBANK

HEALTH

IMMUNOCLONE DATABASE

MEDITEC: BIOMEDICAL ENGINEERING

MEDLINE

NTIS

OCEANIC ABSTRACTS

PNI

POLLUTION ABSTRACTS

SCISEARCH

SWISS LIBRARIES BIOMEDICAL JOURNALS

TOXLINE

WATERNET

WILSON BIOLOGICAL \& AGRICULTURAL INDEX

WILSON GENERAL SCIENCE INDEX

WRA

ZOOLOGICAL RECORD ONLINE

-ARTS AND HUMANITIES SEARCH

BLLDB

QUOTATIONS DATABASE

WILSON HUMANITIES INDEX

-AEROSPACE DATABASE

CEN

CERAMIC ABSTRACTS

COMPENDEX

CONFERENCE PAPERS INDEX

CURRENT CONTENTS SEARCH

ENERGIE

ENGINEERED MATERIALS ABSTRACTS 


\section{GENERAL SUBJECT INDEX}

SUBJECT

Materials Science (cont.)

Mathematics

Mechanical Engineering

See also: Electronics and Electrical Engineering

Medicine

See also: Life Sciences
DATABASE NAME

IAC NEWSLETTER DATABASE

IHS INTERNATIONAL STANDARDS AND SPECIFICATIONS

INSPEC

MATERIALS/B

MATERIALS SCIENCE CITATION INDEX

MECHANICAL ENGINEERING ABSTRACTS

METADEX

PACKAGING SCIENCE AND TECHNOLOGY ABSTRACTS

PAPERCHEM

PASCAL

PLASPEC

POLYMER ONLINE

TEXTILE TECHNOLOGY DIGEST

TRIBO

WORLD TEXTILES

-DISSERTATION ABSTRACTS ONLINE

INSPEC

MATH

MATHEMATICAL DIDACTICS

MATHSCI

NTIS

SCISEARCH

-AEROSPACE DATABASE

AGRICOLA

AUTOMOTIVE ENGINEERING

AUTOMOTIVE INFORMATION AND NEWS SERVICE

COMPENDEX

DIALOG SOURCEONE: ENGINEERING

DKF VEHICLE TEST REPORTS

ENERGY SCIENCE AND TECHNOLOGY

FLUIDEX

GIDEP

INSPEC

MECHANICAL ENGINEERING ABSTRACTS

MOTOR INDUSTRY RESEARCH ASSOCIATION

NTIS

PAPERCHEM

SAE AUTOMOTIVE STANDARDS

SAE GLOBAL MOBILITY

SCISEARCH

TRIS

VOLKSWAGENWERK

WHO MAKES MACHINERY AND PLANT

WPI

-ADIS NEWSLETTERS

ADIS R\&D INSIGHT

AERZTE ZEITUNG

AGELINE 


\section{GENERAL SUBJECT INDEX}

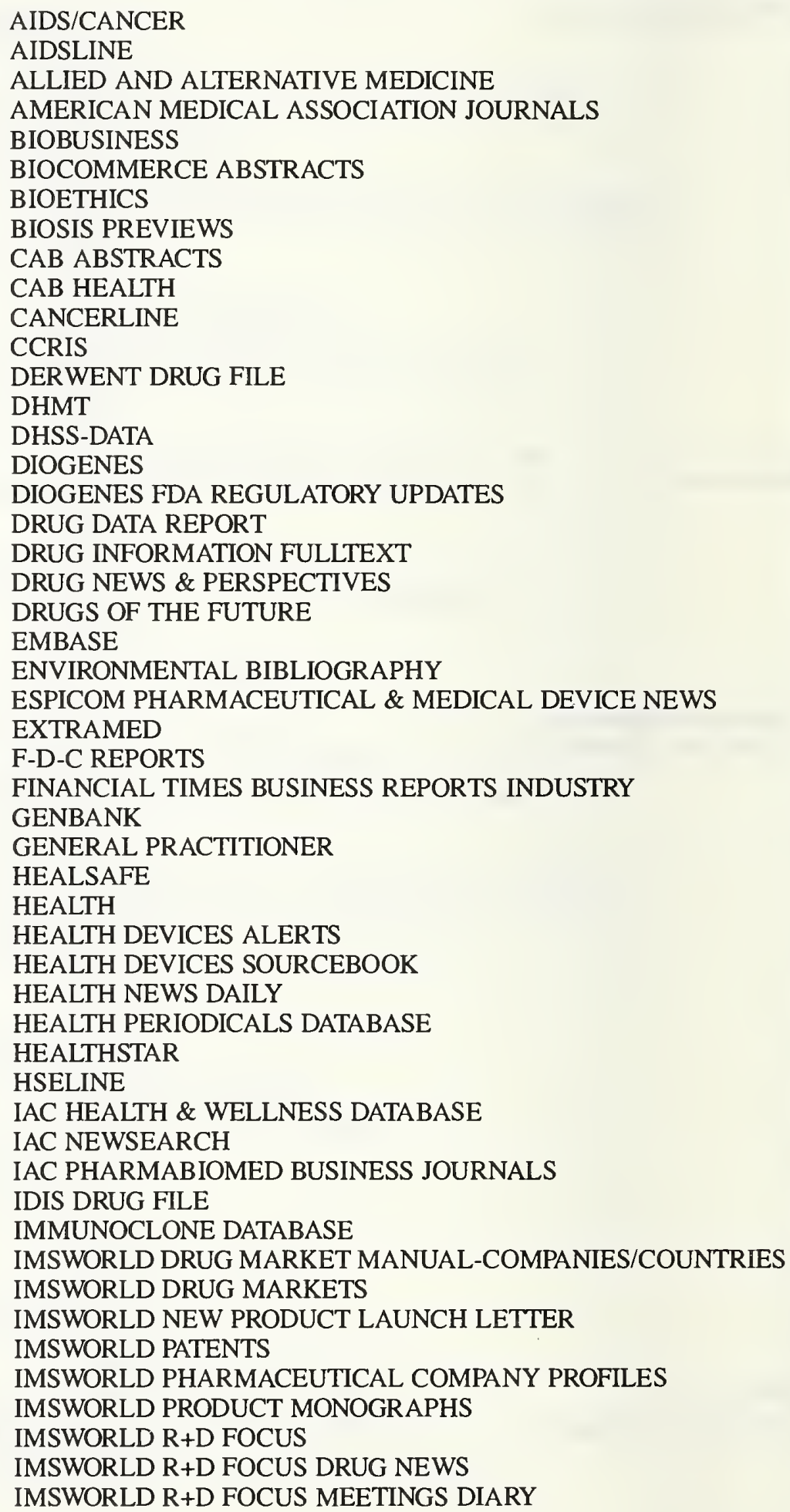




\section{GENERAL SUBJECT INDEX}

\section{SUBJECT}

Medicine (cont.)
DATABASE NAME

INCIDENCE AND PREVALENCE DATABASE

INPHARMA

INTERNATIONAL PHARMACEUTICAL ABSTRACTS

LANCET

LMS DRUG ALERTS

MANUAL, ALTERNATIVE, AND NATURAL THERAPY

MARKETLETTER DATABASE

MARTINDALE PHARMACOPEIA

MDIS COUNTRY HEALTHCARE

MDX HEALTH DIGEST

MEDICONF

MEDITEC: BIOMEDICAL ENGINEERING

MEDLINE

MENTAL HEALTH ABSTRACTS

MERCK INDEX ONLINE

NAPRALERT

NDA PIPELINE

NEW ENGLAND JOURNAL OF MEDICINE

NTIS

NURSING AND ALLIED HEALTH

OCCUPATIONAL SAFETY AND HEALTH

PHARMA MARKETING SERVICE

PHARMACOECONOMICS \& OUTCOMES NEWS

PHARMACONTACTS

PHARMAPROJECTS

PHARMLINE

PNI

PSYCHINFO

REACTIONS DATABASE

SCISEARCH

SEDBASE

SERLINE

SPORT

TOXLINE

TSCATS

21CFR ONLINE

UNLISTED DRUGS

USAN

USP DI VOLUME 1, DRUG

USP DICTIONARY OF USAN AND INTERNATIONAL DRUG NAMES

WILSON GENERAL SCIENCE INDEX

—BUYERS' GUIDE—MEASUREMENT AND CONTROL COMPENDEX

DITR-ZETRIFIZIERUNGSTELLEN

FLUIDEX

GIDEP

IEEE/IEE PUBLICATIONS ONDISC

IHS INTERNATIONAL STANDARDS AND SPECIFICATIONS INSPEC

NTIS 
Metrology and Standardization (cont.)

Mining and Metallurgy

Music

News
SAE AUTOMOTIVE STANDARDS

SCISEARCH

TECHNICAL STANDARDS

-ALUMINUM ASSOCIATION STANDARDS AND DATA ALUMINUM FRACTURE TOUGHNESS DATABASE

ALUMINUM INDUSTRY ABSTRACTS

APILIT

APIPAT

ASMDATA

CHEMICAL ABSTRACTS

COMPENDEX

COPPERDATA

ENERGY SCIENCE AND TECHNOLOGY

ENERGYLINE

ENVIRONMENTAL BIBLIOGRAPHY

GEOARCHIVE

GEOMECHANICS ABSTRACTS

GEOREF

INSPEC

MATERIALS/B

MDF

METADEX

METALCREEP

NTIS

OCEANIC ABSTRACTS

SCISEARCH

SURFACE COATINGS ABSTRACTS

WELDASEARCH

WPI

—WILSON HUMANITIES INDEX

-AFRICA NEWS

AGENCE FRANCE-PRESSE ENGLISH WIRE

AGENCE FRANCE-PRESSE INTERNATIONAL FRENCH WIRE

AMERICA: HISTORY AND LIFE

AMERICAN BANKER

AMERICAN BANKER NEWS

AP NEWS

API ENCOMPASS: NEWS

ASIA INTELLIGENCE WIRE

ASIA PACIFIC BUSINESS NEWS

AUTOMOTIVE INFORMATION AND NEWS SERVICE

BALTIC NEWS SERVICE

BBC MONITORING SUMMARY OF WORLD BROADCASTS

BIOCOMMERCE ABSTRACTS AND DIRECTORY

BLICK-GERMAN BUSINESS NEWS DAILY

BNA DAILY NEWS FROM WASHINGTON

THE BOND BUYER

BUSINESS WIRE 
GENERAL SUBJECT INDEX

SUBJECT

News (cont.)
DATABASE NAME

CABLE, SATELLITE \& TV NEWS

CANADA NEWSWIRE

CANADIAN BUSINESS AND CURRENT AFFAIRS

CANADIAN NEWSPAPERS

CIN

COMPUTER NEWS FULLTEXT

DIALOG HEADLINES

DOW JONES NEWS/RETRIEVAL

EARLY EDITION-CANADA

EARLY EDITION-US

EUROPEAN CHEMICAL NEWS

FEDERAL NEWS SERVICE

FINANCIAL TIMES FULLTEXT

DE FINANCIEEL EKONOMISCHE TIJD

FRANKFURTER ALLGEMEINE ZEITUNG

HEALTH NEWS DAILY

IAC GLOBALBASE

IAC NEWSWIRE ASAP

INDEPENDENT (LONDON)

INFO LATINO AMERICA

ITAR/TASS NEWS

JAPAN NEWS WIRE

JERUSALEM POST ELECTRONIC EDITION

JPNEWS

LATIN AMERICAN NEWS

MAGAZINE INDEX

LE MONDE

MOSCOW NEWS

NATIONAL NEWSPAPER INDEX

NEUE ZUERCHER ZEITUNG

NEW YORK TIMES

NEW ZEALAND NEWSPAPERS

NEWSPAPER ABSTRACTS

NEWSPAPER ABSTRACTS DAILY

NEXIS

PAPERS

PHARMACOECONOMICS \& OUTCOMES NEWS

PR NEWSWIRE

REUTERS

RUSSIAN AND CIS NEWS

SOLE

SOUTH CHINA MORNING POST

LA STAMPA

SOUTH AMERICAN BUSINESS INFORMATION

SUEDDEUTSCHE ZEITUNG

TEXTLINE

TIMES/SUNDAY TIMES (LONDON)

LA TRIBUNE DB

TV \& RADIO TRANSCRIPTS DAILY

UMI/DATATIMES

UPI NEWS 
News (cont.)

Nuclear Science

Patents
WALL STREET JOURNAL ABSTRACTS WORLD REPORTER XINHUA NEWS

CHEMICAL ABSTRACTS
COMPENDEX
ENERGY SCIENCE AND ENERGY SCIENCE AND TECHNOLOGY ENERGYLINE GIDEP INIS INSPEC NTIS NUCLEAR SCIENCE ABSTRACTS POLLUTION ABSTRACTS SCISEARCH SPIN

-APIPAT

CHINESE PATENT ABSTRACTS CLAIMS/CITATION CLAIMS/COMPOUND REGISTRY CLAIMS/REASSIGNMENT \& REEXAMINATION CLAIMS/REFERENCE

CLAIMS/U.S. PATENTS CLAIMS/UNITERM CURRENT PATENTS FAST ALERT DERWENT PATENTS CITATION INDEX DGENE

DRUG PATENTS INTERNATIONAL EUROPATFUL EUROPEAN PATENTS FULLTEXT IMSWORLD PATENTS

INPADOC

JAPIO

PATDPA

PATOSDE

PATOSEP

PATOSWO

TEXTLINE GLOBAL NEWS

TRADEMARKSCAN AUSTRIA

TRADEMARKSCAN BELELUX

TRADEMARKSCAN CANADA

TRADEMARKSCAN DENMARK

TRADEMARKSCAN-EUROPEAN COMMUNITY

TRADEMARKSCAN FRANCE

TRADEMARKSCAN GERMANY

TRADEMARKSCAN INTERNATIONAL REGISTER

TRADEMARKSCAN ITALY

TRADEMARKSCAN LIECHTENSTEIN

TRADEMARKSCAN MONACO

TRADEMARKSCAN SWITZERLAND 


\section{GENERAL SUBJECT INDEX}

SUBJECT

Patents (cont.)

Philosophy

Physics

Psychology

Public Administration

Religion
DATABASE NAME

TRADEMARKSCAN-U.K.

TRADEMARKSCAN-U.S. FEDERAL

TRADEMARKSCAN-U.S. STATE

U.S. PATENTS FULLTEXT

WPI

-PHILOSOPHER'S INDEX

SOCIAL SCISEARCH

WILSON HUMANITIES INDEX

-AEROSPACE DATABASE

CHEMICAL ABSTRACTS

COMPENDEX

DELURA

ENERGY SCIENCE AND TECHNOLOGY

INPHYS

INSPEC

MATERIALS SCIENCE CITATION INDEX

NTIS

NUCLEAR SCIENCE ABSTRACTS

PINET

SCISEARCH

SOLIDSTATE

SPIN

TRIBO

WILSON GENERAL SCIENCE INDEX

WORLD ALUMINUM ABSTRACTS

-EMBASE

LINGUISTICS AND LANGUAGE BEHAVIOR ABSTRACTS

MENTAL HEALTH ABSTRACTS

PSYCHINFO

SOCIAL SCISEARCH

SOCIOLOGICAL ABSTRACTS

-ABI/INFORM

BBC MONITORING SUMMARY OF WORLD BROADCASTS

BNA DAILY NEWS FROM WASHINGTON

CONGRESSIONAL RECORD

COUNTRY REPORT SERVICE

FEDERAL NEWS SERVICE

MANAGEMENT CONTENTS

MONEYCLIPS

PAIS INTERNATIONAL

PUBLIC OPINION ONLINE

SCAN-A-BID

SOCIAL SCISEARCH

-BIBLE

WILSON HUMANITIES INDEX 
Safety

Social Sciences

Sports

Statistics

Telecommunications

Textiles

Toxicology
- CHEMICAL SAFETY NEWSBASE

CHEMSAFE

HEALSAFE

HSDB

HSELINE

MSDS-CCOHS

OCCUPATIONAL SAFETY AND HEALTH

OHS MSDS

PESTLINE

-AGELINE

ASSIA: APPLIED SOCIAL SCIENCES INDEX AND ABSTRACTS

CRIMINAL JUSTICE PERIODICAL INDEX

DRUG

EBIS-EMPLOYEE BENEFITS INFOSOURCE

FAMILY RESOURCES

FORIS

HISTORICAL ABSTRACTS

INFO LATINO AMERICA

LINGUISTICS AND LANGUAGE BEHAVIOR ABSTRACTS

NCJRS

PAIS INTERNATIONAL

POPULATION DEMOGRAPHICS

RSWB

SOCIAL SCISEARCH

SOCIOLOGICAL ABSTRACTS

SOLIS

SPORT

WILSON SOCIAL SCIENCES ABSTRACTS

-SPORT

-ASI

-CABLE, SATELLITE \& TV NEWS

ESPICOM TELECOMMUNICATIONS/POWER REPORTS KR TELECOMMUNICATIONS NEWSLETTERS

- CHEMICAL ABSTRACTS

PAPERCHEM

TEXTILE TECHNOLOGY DIGEST

WORLD TEXTILES

WPI

- CHEMICAL ABSTRACTS

CHEMICAL SAFETY NEWSBASE

DHMT

EMBASE

HSDB

INTERNATIONAL PHARMACEUTICAL ABSTRACTS

MSDS-CCOHS 


\section{GENERAL SUBJECT INDEX}

SUBJECT

Toxicology (cont.)

Translations

Transportation and Utilities
DATABASE NAME

OHS MSDS

POLLUTION ABSTRACTS

RTECS

TOXLINE

-WORLD TRANSLATIONS INDEX

-COMPENDEX

CONFERENCE PAPERS INDEX

ENERGY SCIENCE AND TECHNOLOGY

EPD

OAG ELECTRONIC EDITION

OCEANIC ABSTRACTS

PAIS INTERNATIONAL

POLLUTION ABSTRACTS

SAE GLOBAL MOBILITY

SOCIAL SCISEARCH

TRIS

VOLKSWAGENWERK

WPI

-BIOSIS PREVIEWS

ZOOLOGICAL RECORD 
Abstract Bulletin of the Institute of Paper Science and Technology

Abstracted Business Information/Inform

Abstracts in Biocommerce

Accounting \& Tax Index

ACM Guide to Computing Literature

Agricultural On-Line Access

AGRINDEX

Agrochemicals Handbook

AHL

Algology, Mycology and Protozoology

American Banker

American Doctoral Dissertations

American Men and Women of Science

American Statistics Index

American Theological Library Association Religion

Amino-Acids, Peptides and Proteins

Analytica Chimica Acta

Angewandte Chemie

Animal Behavior Abstracts

Annual Report and Accounts

API Literature Abstracts

Applied Catalysis

Applied Science and Technology Index

Aquatic Sciences and Fisheries Abstracts

Architectural Periodicals Index

Architectural Books Catalogue

The Associated Press

Automotive Abstracts

Bacteriology Abstracts

Barron's

BHRA Fluid Engineering Abstracts

Bibliographie Internationale

Bibliography and Index of Geology

Bibliography and Index of Geology Exclusive of North America

Bibliography and Index of North American Geology

Bibliography of Agriculture

Bibliography of Bioethics

Bibliography of Linguistic Literature Database

Bibliography of the History of Medicine

Bibliography of Thesis in Geology

Biochemistry Abstracts

Biological Abstracts

Biological \& Agricultural Index

Biotechnology Research Abstracts

BMFT Support Catalog

\author{
PAPERCHEM
}

\author{
ABI/INFORM \\ BIOCOMMERCE ABSTRACTS AND DIRECTORY \\ ACCOUNTING \& TAX DATABASE \\ COMPUSCIENCE \\ MATHSCI \\ AGRICOLA \\ AGRIS INTERNATIONAL \\ PESTICIDE FACT FILE \\ AMERICA: HISTORY AND LIFE \\ CAMBRIDGE SCIENTIFIC ABSTRACTS LIFE SCIENCE \\ BANKER \\ DISSERTATION ABSTRACTS ONLINE \\ BOWKER BIOGRAPHICAL DIRECTORY \\ ASI \\ RELIGION INDEX \\ CAMBRIDGE SCIENTIFIC ABSTRACTS LIFE SCIENCE \\ CJELSEVIER \\ $\mathrm{CJVCH}$ \\ CAMBRIDGE SCIENTIFIC ABSTRACTS LIFE SCIENCE \\ ICC BRITISH COMPANY ANNUAL REPORTS \\ APILIT \\ CJELSEVIER \\ WILSON APPLIED SCIENCE AND TECHNOLOGY \\ INDEX \\ ASFA \\ ARCHITECTURE DATABASE \\ ARCHITECTURE DATABASE \\ AP NEWS \\ SAE GLOBAL MOBILITY
}

CAMBRIDGE SCIENTIFIC ABSTRACTS LIFE SCIENCE DOW JONES NEWS/RETRIEVAL

FLUIDEX

PASCAL

GEOREF

GEOREF

GEOREF

AGRICOLA

BIOETHICS

BLLDB

HISTLINE

GEOREF

CAMBRIDGE SCIENTIFIC ABSTRACTS LIFE SCIENCE BIOSIS PREVIEWS

WILSON BIOLOGICAL \& AGRICULTURAL INDEX

CAMBRIDGE SCIENTIFIC ABSTRACTS LIFE SCIENCE FORKAT 
Bundesanzeiger

Business Periodicals Index

CA Chemical Name Dictionary

Calcified Tissue Abstracts

Calgary Herald

Cancer Literature

Cancer Therapy Abstracts

Carbohydrate Research

Carcinogenesis Abstracts

CASIA

CDI

CHEM Sources International

CHEM Sources USA

Chemical Abstracts Chemical Name Directory

Chemical and Engineering News

Chemical Carcinogenesis Research Information System

Chemical Dictionary On-Line

Chemical Evaluation Search and Retrieval System

Chemical Hazard Response Information System

Chemical Industry Notes

Chemoreception Abstracts

City and State Directories in Print

Code of Federal Regulations

Commonwealth Agricultural Bureaux Abstracts

Compound Term List Molecular Formula Order

Compound Term List Name/Number Order

Comprehensive Dissertation Index

Computer and Control Abstracts

Computer and Information Systems Abstracts Journal

Computerized Engineering Index

Computerworld

Computing Reviews

Corporate Technology Directory

CPI

CRC Handbook of Data on Organic Compounds

Current Index to Journals in Education

Current Index to Statistics

Current Law Index

Current Physics Index

Current Research Information System

Current Technology Index

Cyberhound's Guide to Internet Databases

\author{
ECONOVO \\ ECOREGISTER \\ WILSON BUSINESS ABSTRACTS FULLTEXT \\ WILSON BUSINESS PERIODICALS INDEX
}

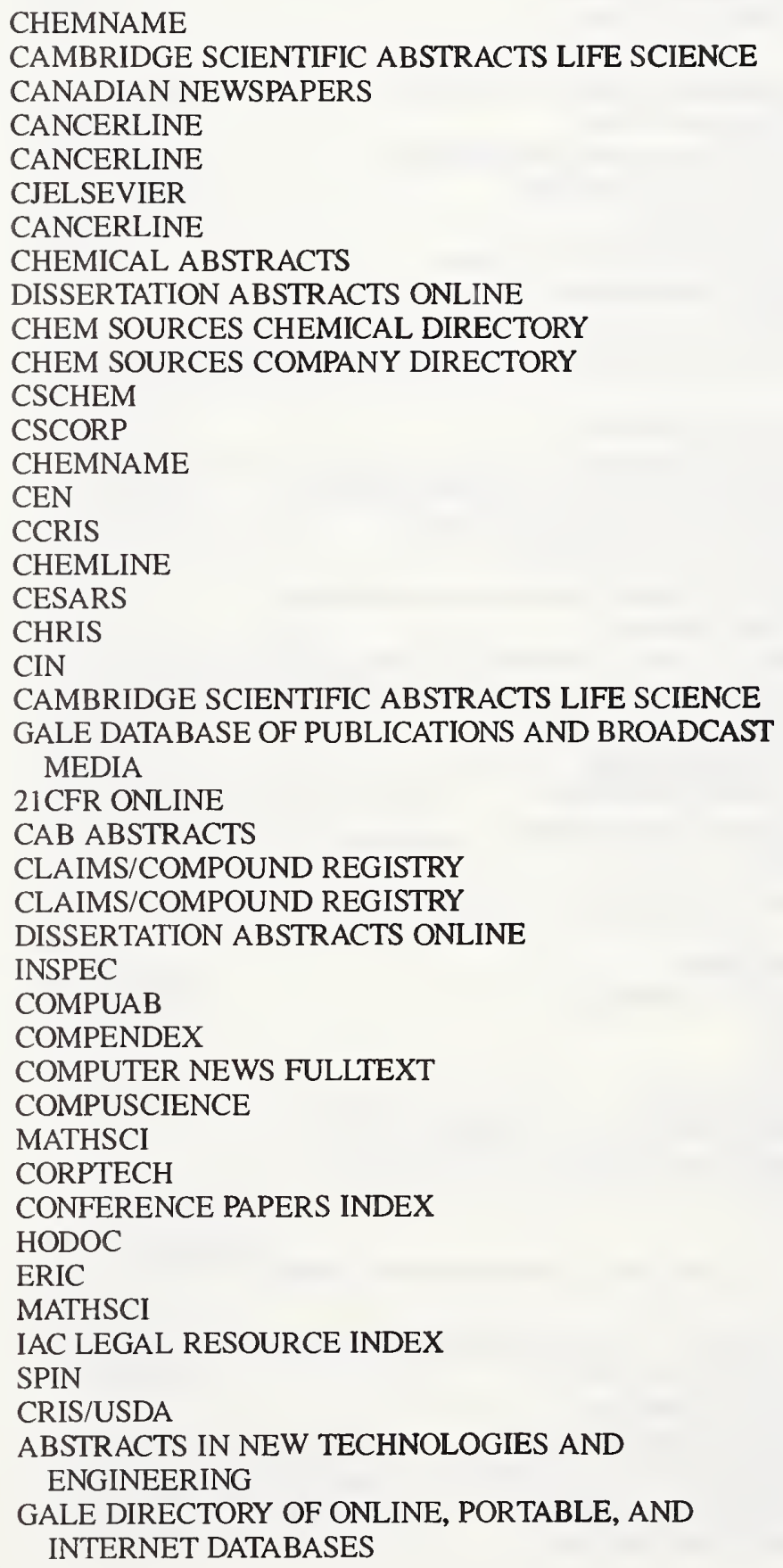

CHEMNAME

CAMBRIDGE SCIENTIFIC ABSTRACTS LIFE SCIENCE

CANADIAN NEWSPAPERS

CANCERLINE

CANCERLINE

CJELSEVIER

CANCERLINE

CHEMICAL ABSTRACTS

DISSERTATION ABSTRACTS ONLINE

CHEM SOURCES CHEMICAL DIRECTORY

CHEM SOURCES COMPANY DIRECTORY

CSCHEM

CSCORP

CHEMNAME

CEN

CCRIS

CHEMLINE

CESARS

CHRIS

CIN

CAMBRIDGE SCIENTIFIC ABSTRACTS LIFE SCIENCE

GALE DATABASE OF PUBLICATIONS AND BROADCAST

MEDIA

21CFR ONLINE

CAB ABSTRACTS

CLAIMS/COMPOUND REGISTRY

CLAIMS/COMPOUND REGISTRY

DISSERTATION ABSTRACTS ONLINE

INSPEC

COMPUAB

COMPENDEX

COMPUTER NEWS FULLTEXT

COMPUSCIENCE

MATHSCI

CORPTECH

CONFERENCE PAPERS INDEX

HODOC

ERIC

MATHSCI

IAC LEGAL RESOURCE INDEX

SPIN

CRIS/USDA

ABSTRACTS IN NEW TECHNOLOGIES AND

ENGINEERING

GALE DIRECTORY OF ONLINE, PORTABLE, AND INTERNET DATABASES 
Dechema Thermophysical Property Data Bank

Defense RDT+E On-Line System

Defense Technical Information Center

Design Institute for Physical Property Data

Development Business

Directories in Print

Dissertation Abstracts International

Dissertation Index

DKF-Literaturinformations Dienst

DOE Energy Data Base

The Dominion

Drug Info/Alcohol Use-Abuse

Drug Literature Index

DTIC

Dun's Guide to Israel

\section{Ecological Abstracts}

Ecology Abstracts

Educational Resources Information Center

Electrical and Electronic Abstracts

Electric Power Database

Electronics and Communications Abstracts

Energy Abstracts

Energy Abstracts for Policy Analysis

Energy Information Abstracts

Energy Research Abstracts

Engineering Index

Entomology Abstracts

Environment Abstracts

EPB

Exerpta Medica

F\&S Index

Faculty Alert Bulletin

FD

FGI

Financial Post

FIND/SVP Reports and Studies Index

Foundation News

FSTA

GALE Directory of Publications and Broadcast Media

The Gazette

General Science Index

Genetics Abstracts

Geographical Abstracts

Geological Abstracts Service

Geological Reference File

Geophysical Abstracts

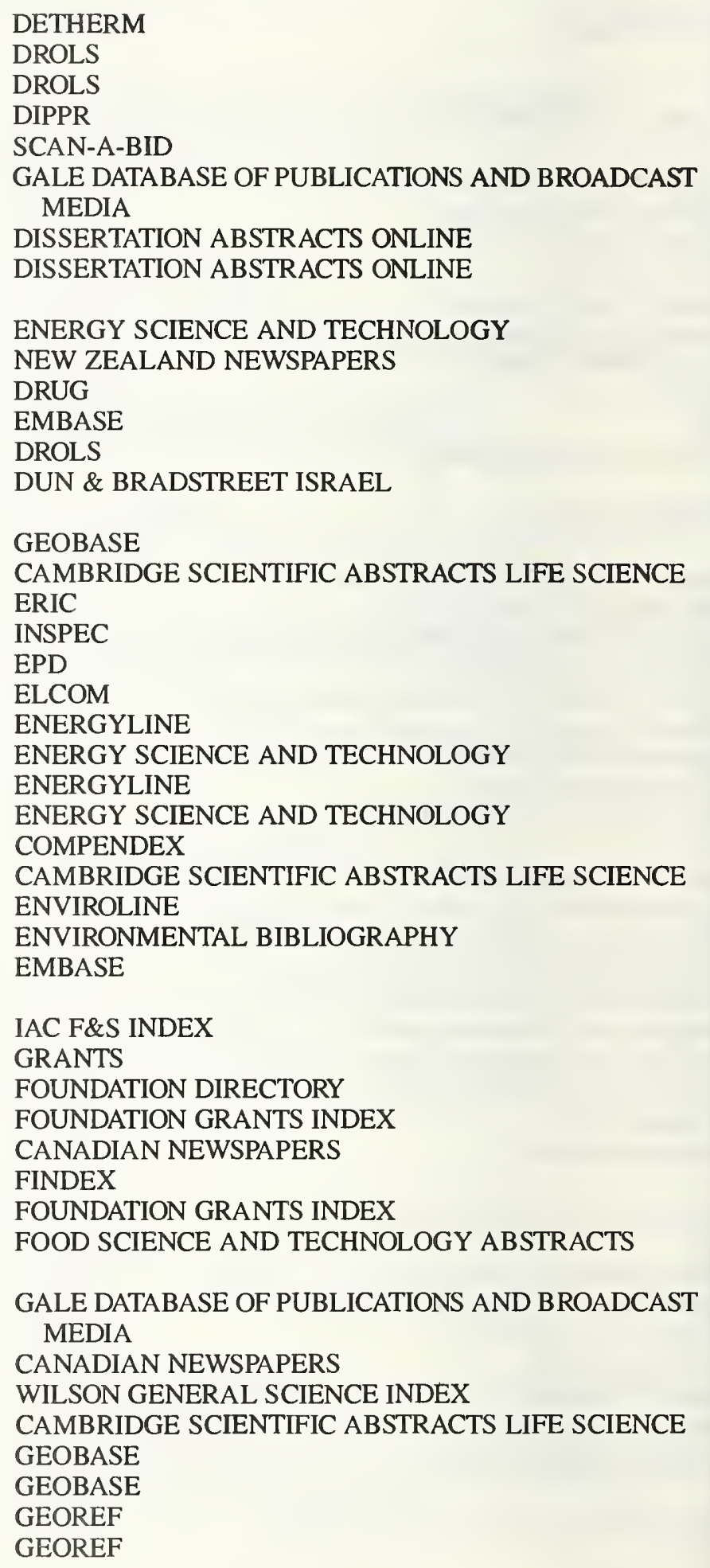




\section{CROSS REFERENCE INDEX}

German National Bibliography

Government--Industry Data Exchange Program

Government Reports Announcements

Government Research Directory

GP-General Practitioner

GRA

Grant Information System

Health and Safety Sciences Abstracts

Health Planning and Administration

History of Medicine On-Line

Hospital and Health Administration Index

Hospital Literature Index

HRIS Abstracts

Immunology Abstracts

L'Impresa

Index Medicus

Index to Statistics and Probability

Industrial and Applied Microbiology

Inform

Information Bank

Information Technology

Inorganic Crystal Structure Database

Inpharma

International Aerospace Abstracts

International Brands and Their Companies

International Development Abstracts

International Research Centers Directory

International Reviews on Mathematical Education

IPA

Jane's Defense Weekly

Japar Patent Information Organization

Journal AWWA

Journal of Organometallic Chemistry

Journal of the Association of Official Analytical Chemists

Keynote Reports

Language and Language Behavior Abstracts

Leisure, Recreation and Tourism Abstracts

Library and Information Science Abstracts

Library of Congress

LLBA

Market Research Europe

Market Research Great Britian

Market Research International
DATABASE NAME
BIBLIODATA

GIDEP

NTIS

RESEARCH CENTERS AND SERVICES DIRECTORY

GENERAL PRACTITIONER

NTIS

GRANTS

HEALSAFE
HEALTH
HISTLINE
HEALTHSTAR
HEALTH
TRIS

CAMBRIDGE SCIENTIFIC ABSTRACTS LIFE SCIENCE MONDO ECONOMICO, L'IMPRESA

MEDLINE

MATHSCI

CAMBRIDGE SCIENTIFIC ABSTRACTS LIFE SCIENCE

ABI/INFORM

NEW YORK TIMES

INSPEC

ICSD

ADIS NEWSLETTERS

AEROSPACE DATABASE

TRADE NAMES DATABASE

GEOBASE

RESEARCH CENTERS AND SERVICES DIRECTORY

MATHEMATICAL DIDACTICS

INTERNATIONAL PHARMACEUTICAL ABSTRACTS

JANE'S DEFENSE AND AEROSPACE NEWS/ANALYSIS

JAPIO

WATERNET

CJELSEVIER

CJAOAC

ICC KEY NOTE MARKET ANALYSIS

LINGUISTICS AND LANGUAGE BEHAVIOR

ABSTRACTS

CAB ABSTRACTS

LISA

LC MARC

LINGUISTICS AND LANGUAGE BEHAVIOR

ABSTRACTS

EUROMONITOR JOURNALS

EUROMONITOR JOURNALS

EUROMONITOR JOURNALS 


\section{CROSS REFERENCE INDEX}

\section{DATABASE OR HARD COPY}

Mathematical Reviews

MDCA News

\section{MEDECONOMICS}

Medistat News

MEDLARS On-Line

Metals Abstracts/Alloys Index

MGA

Microbiology Abstracts

Million Dollar Directory

MIMS Magazine

Mineralogical Abstracts

Monthly Catalog of U.S. Government Publications

Monthly Operational Summaries of the World Bank

MRIS Abstracts

National Criminal Justice Reference Service

National Technical Information Service

NBS Technical Note 1097

Nederlands ABC Voor Handel en Industrie

Network World

Newsletter in Print

\section{Nonferrous Alert}

Normteilprodukte

El Norte

Nucleic Acids

\section{Oesterreich 2000}

The Official Journal of the European Communities, Supplement $S$

The Ottawa Citizen

Oxford Dictionary of Quotations

\section{PA}

Packaging Abstracts

Paper and Board Abstracts

PATELL

Patent Abstracts of Japan

PCA News

Pesticides Manual

Peterson's Annual Guides/Graduate Study

Petroleum Abstracts

Petroleum/Energy Business News Index

Pharma Marketing News

Pharmaceutical News Index

Pharmocoeconomics \& Outcomes News

Physics Abstracts

Physics Briefs/Physikalische Berichte

Physics Information Network

\section{DATABASE NAME}

\author{
MATHSCI \\ ESPICOM PHARMACEUTICAL \& MEDICAL DEVICE \\ NEWS \\ GENERAL PRACTITIONER \\ ESPICOM PHARMACEUTICAL \& MEDICAL DEVICE \\ NEWS \\ MEDLINE \\ METADEX \\ METEOROLOGICAL AND GEOASTROPHYSICAL \\ ABSTRACTS \\ CAMBRIDGE SCIENTIFIC ABSTRACTS LIFE SCIENCE \\ D\&B-DUN'S MARKET IDENTIFIERS \\ GENERAL PRACTITIONER \\ GEOBASE \\ GPO MONTHLY CATALOG \\ SUMMARY OF PROPOSED PROJECTS \\ TRIS
}

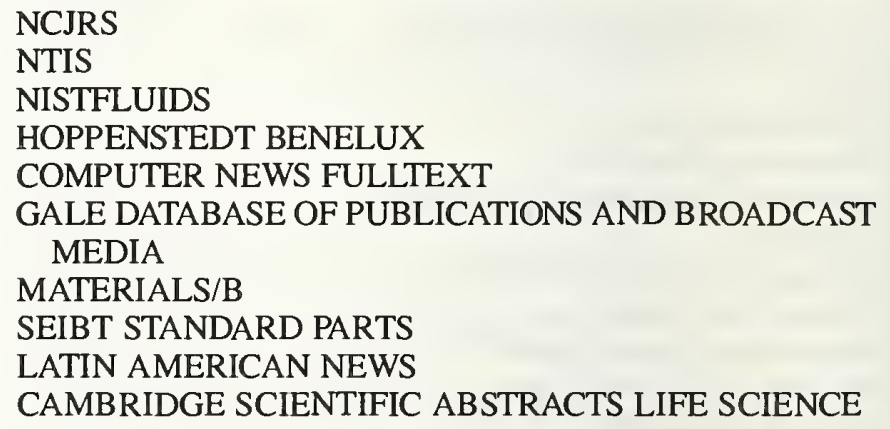

NCJRS

NTIS

NISTFLUIDS

HOPPENSTEDT BENELUX

COMPUTER NEWS FULLTEXT

GALE DATABASE OF PUBLICATIONS AND BROADCAST MEDIA

MATERIALS/B

SEIBT STANDARD PARTS

LATIN AMERICAN NEWS

CAMBRIDGE SCIENTIFIC ABSTRACTS LIFE SCIENCE

HOPPENSTEDT AUSTRIA

TENDERS ELECTRONIC DAILY

CANADIAN NEWSPAPERS

QUOTATIONS DATABASE

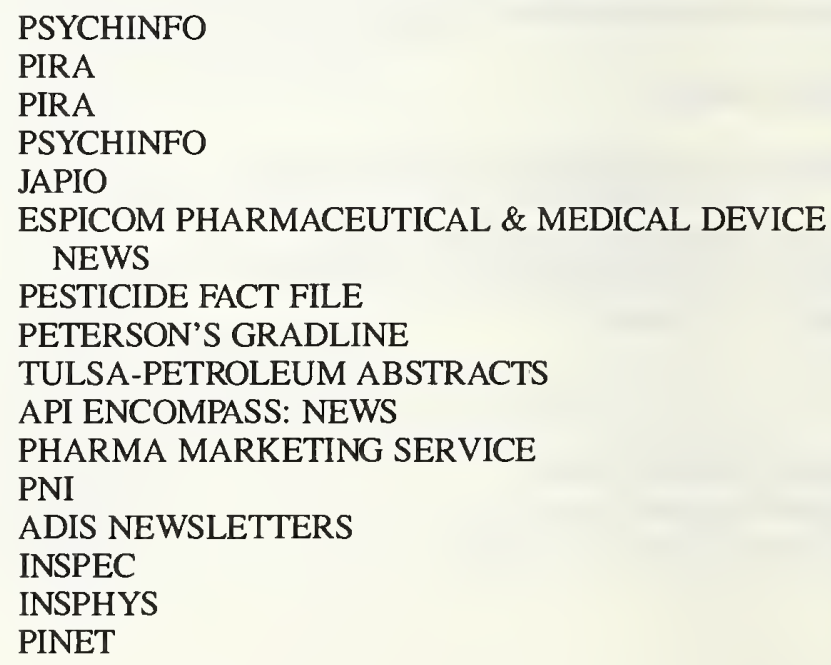




\section{CROSS REFERENCE INDEX}

Polymer/Ceramics/Composites Alert

The Press

Psychological Abstracts

Public Affairs Information Service

Quarterly Operational Summary of the African

Development Bank

\section{R+D Focus}

Reactions

Reactions Weekly

Readers' Guide to Periodical Literature

Reading Abstracts

Reforma

REFPROP

Registry of Toxic Effects of Chemical Substances

Research Centers Directory

Research in Education

Research Services Directory

Retail Monitor International

Retrospective Machine Readable Cataloging

Review of Metal Literature

RILA

SAE Quarterly Abstracts

Science Abstracts

Science Citation Index

Scientific and Technical Aerospace Reports

Searchable Physics Information Notices

Selected Water Resources Abstracts

Serials On-Line

Social Sciences Citation Index

Social Sciences Abstracts

Society of Automotive Engineers

Sport and Recreation Index

Steels Alert

Sunday Star-Times

SWRA

Technical Abstract Bulletin

Technical Reports in Computer Science

The Times of London

The Toronto Star

Toxic Substances Control Act (TSCA) Initial Inventory

Toxicology Abstracts

Toxicology Information On-Line

Transportation Research Information Services

\author{
MATERIALS/B \\ NEW ZEALAND NEWSPAPERS \\ PSYCHINFO \\ PAIS
}

SUMMARY OF PROPOSED PROJECTS

\author{
IMSWORLD R+D FOCUS \\ ADIS NEWSLETTERS \\ REACTIONS DATABASE \\ WILSON READERS' GUIDE TO PERIODICAL \\ LITERATURE \\ LINGUISTICS AND LANGUAGE BEHAVIOR \\ ABSTRACTS \\ LATIN AMERICAN NEWS \\ NIST THERMODYNAMIC PROPERTIES OF \\ REFRIGERANTS AND REFRIGERANT MIXTURES \\ RTECS \\ RESEARCH CENTERS AND SERVICES DIRECTORY \\ ERIC
RESEARCH CENTERS AND SERVICES DIRECTORY
EUROMONITOR JOURNALS
REMARC
METADEX \\ ART LITERATURE INTERNATIONAL
}

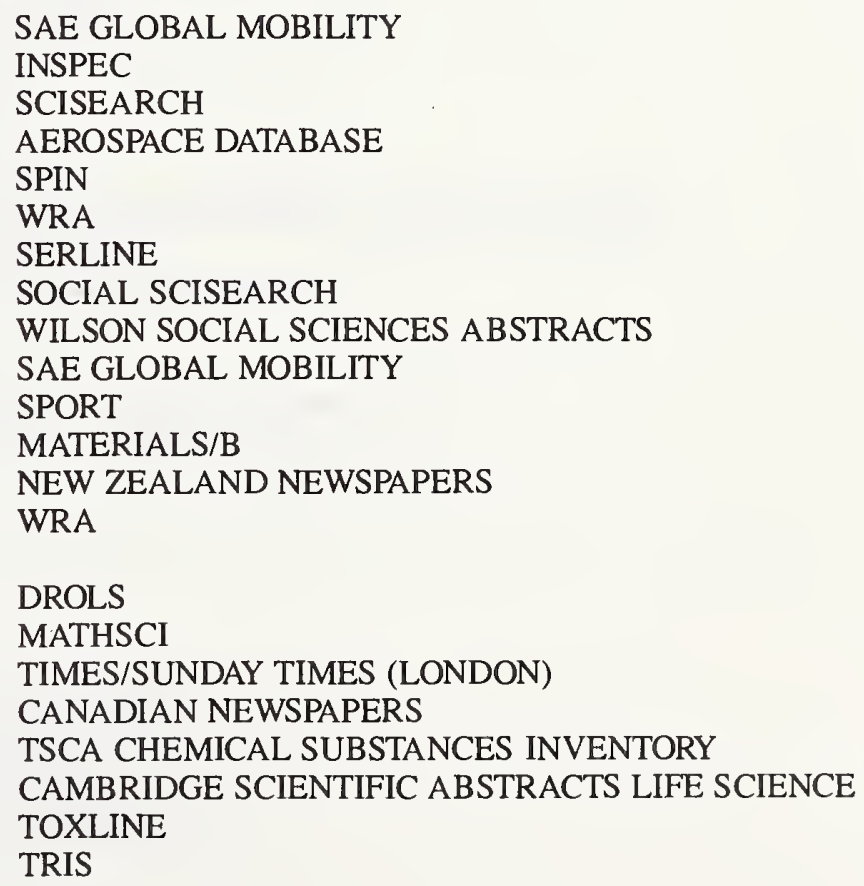

DROLS

MATHSCI

TIMES/SUNDAY TIMES (LONDON)

CANADIAN NEWSPAPERS

TSCA CHEMICAL SUBSTANCES INVENTORY

CAMBRIDGE SCIENTIFIC ABSTRACTS LIFE SCIENCE

TOXLINE

TRIS 


\section{CROSS REFERENCE INDEX}

\section{DATABASE OR HARD COPY}

\section{UFOKAT}

U.S. Patent Alert

U.S. Patent Master Classification File

U.S. Patent Official Gazette

The Vancouver Sun

Virology and AIDS Abstracts

Wall Street Journal

Water Resources Abstracts

Who's Who in American Art

Who's Who in American Politics

World Drug Market Manual-Countries

World Patent Index

World Surface Coatings Abstracts

World Textile Abstracts

WTA

Zentralblatt für Mathematik
SEE

DATABASE NAME

UFORDAT

USPA

USCLASS

CLAIMS/U.S. PATENTS

CANADIAN NEWSPAPERS

CAMBRIDGE SCIENTIFIC ABSTRACTS LIFE SCIENCE

DOW JONES NEWS/RETRIEVAL

WRA

BOWKER BIOGRAPHICAL DIRECTORY

BOWKER BIOGRAPHICAL DIRECTORY

IMSWORLD DRUG MARKETS

WPI

SURFACE COATINGS ABSTRACTS

WORLD TEXTILES

WORLD TEXTILES

MATH 


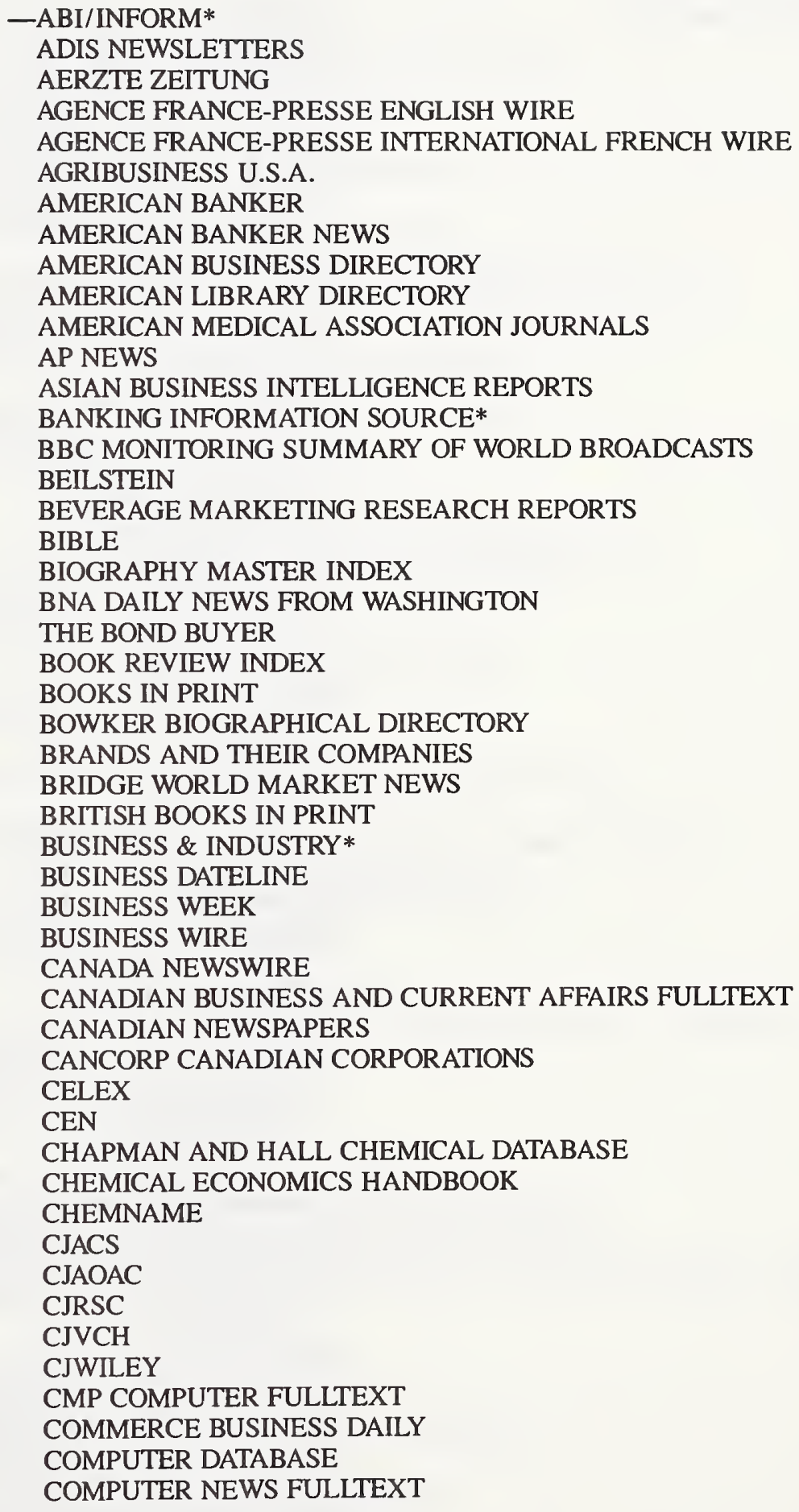

*Some full text titles 
Full Text Data Bases (cont.)

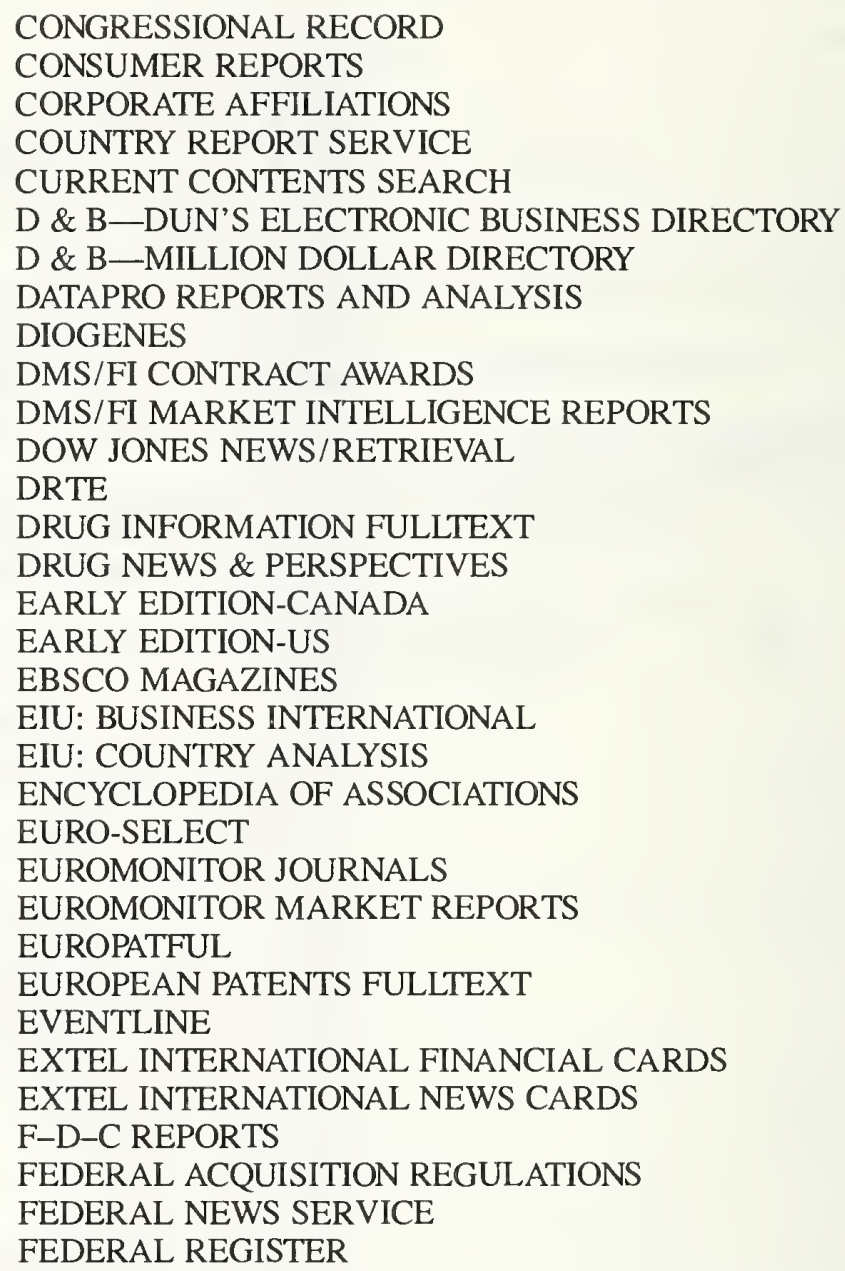


Full Text Data Bases (cont.)

\section{GENERAL PRACTITIONER \\ GENERAL SCIENCE ABSTRACTS/FULLTEXT \\ GRANTS \\ HARVARD BUSINESS REVIEW \\ HEALTH DEVICES ALERTS \\ HEALTH DEVICES SOURCEBOOK \\ HEALTH NEWS DAILY \\ HEALTH PERIODICALS DATABASE}

HOPPENSTEDT DIRECTORY OF GERMAN COMPANIES

HUMANITIES ABSTRACTS FULL TEXT

IAC BUSINESS A.R.T.S.*

IAC HEALTH \& WELLNESS DATABASE*

IAC INDUSTRY EXPRESS

IAC NEW PRODUCT ANNOUNCEMENTS

IAC NEWSLETTER DATABASE

IAC NEWSWIRE

ICC BRITISH COMPANY DIRECTORY

ICC BRITISH COMPANY FINANCIAL DATA SHEETS

ICC INTERNATIONAL BUSINESS RESEARCH

IEEE/IEE PUBLICATIONS ONDISC

IMSWORLD PATENTS

IMSWORLD R+D FOCUS DRUG NEWS

INDEPENDENT (LONDON)

INPHARMA

INSIDER TRADING MONITOR

INTERNATIONAL RISK AND PAYMENT REVIEW

INVESTEXT

JANE'S DEFENSE AND AEROSPACE NEWS/ANALYSIS

JAPAN ECONOMIC NEWSWIRE PLUS

JERUSALEM POST ELECTRONIC EDITION

JOURNAL OF COMMERCE

JPNEWS

JUPITER MARKET RESEARCH

KIRK OTHMER ENCYCLOPEDIA OF CHEMICAL TECHNOLOGY

KOMPASS ASIA/PACIFIC

KOMPASS CANADA

KOMPASS EUROPE

KOMPASS UK

KR DEFENSE NEWSLETTERS

KR FINANCE AND BANKING NEWSLETTERS

KR TELECOMMUNICATIONS NEWSLETTERS

LAFFERTY BANKING, INSURANCE, AND PROFESSIONAL SERVICES INTELLIGENCE

LANCET

LATIN AMERICAN NEWS

LEXIS

MCGRAW-HILL PUBLICATIONS ONLINE

MAGAZINE INDEX*

MAGILL'S SURVEY OF CINEMA

MANAGEMENT CONTENTS*

*Some full text titles 
MARKET \& BUSINESS DEVELOPMENT MARKETLETTER DATABASE MARKETLINE MARKET REPORTS MARQUIS WHO'S WHO MERCK INDEX ONLINE MILLER FREEMAN INDUSTRY AND PRODUCT NEWS MONDO ECONOMICO, L'IMPRESA MOODY'S CORPORATE NEWS-INTERNATIONAL MOSCOW NEWS

MSI REPORTS

NEUE ZUERCHER ZEITUNG

NEW ENGLAND JOURNAL OF MEDICINE

NEW YORK TIMES

NEW ZEALAND NEWSPAPERS

NEXIS

OAG ELECTRONIC EDITION

OHS MSDS

PAPERS

PERIODICAL ABSTRACTS PLUSTEXT*

PETERSON'S COLLEGE DATABASE

PETERSON'S GRADLINE

PHARMACEUTICAL COMPANY PROFILES

PHARMAPROJECTS

PHIND

POLYMER ONLINE

PR NEWSWIRE

PUBLIC OPINION ONLINE

PUBLISHERS, DISTRIBUTORS AND WHOLESALERS

QUEST ECONOMICS DATABASE

QUOTATIONS DATABASE

REACTIONS DATABASE

RESEARCH CENTERS AND SERVICES DIRECTORY

REUTERS

RTECS

SEC ONLINE

SOLE

SOUTH CHINA MORNING POST

LA STAMPA

STANDARD AND POOR'S NEWS

STANDARD AND POOR'S REGISTER-BIOGRAPHICAL STANDARD AND POOR'S REGISTER-CORPORATE SUEDDEUTSCHE ZEITUNG

SUMMARY OF PROPOSED PROJECTS

TAX NOTES TODAY

TEXTLINE GLOBAL NEWS

THOMAS REGISTER ONLINE

TIMES/SUNDAY TIMES (LONDON)

TRADE AND INDUSTRY DATABASE*

*Some full text titles 


\section{FULL TEXT DATABASES}

SUBJECT

Full Text Data Bases (cont.)
DATABASE NAME

TRADEMARKSCAN-U.S. FEDERAL

TRADEMARKSCAN-U.S. STATE

TRADEMARKSCAN-U.K.

TV \& RADIO TRANSCRIPTS DAILY

21CFR ONLINE

ULRICH'S INTERNATIONAL PERIODICAL DIRECTORY

UMI/DATATIMES

UPI NEWS

WILSON BUSINESS ABSTRACTS FULLTEXT

WILSON GENERAL SCIENCE INDEX/FULLTEXT

WILSON READERS' GUIDE ABSTRACTS FULL TEXT

YELLOW BOOKS: CORPORATE AND FINANCIAL

YELLOW BOOKS: LAW FIRMS

XINHUA NEWS 

Journal of Research of the National Institute of Standards and Technology-Reports NIST research and development in those disciplines of the physical and engineering sciences in which the Institute is active. These include physics, chemistry, engineering, mathematics, and computer sciences. Papers cover a broad range of subjects, with major emphasis on measurement methodology and the basic technology underlying standardization. Also included from time to time are survey articles on topics closely related to the Institute's technical and scientific programs. Issued six times a year.

\section{Nonperiodicals}

Monographs-Major contributions to the technical literature on various subjects related to the Institute's scientific and technical activities.

Handbooks-Recommended codes of engineering and industrial practice (including safety codes) developed in cooperation with interested industries, professional organizations, and regulatory bodies.

Special Publications-Include proceedings of conferences sponsored by NIST, NIST annual reports, and other special publications appropriate to this grouping such as wall charts, pocket cards, and bibliographies.

National Standard Reference Data Series-Provides quantitative data on the physical and chemical properties of materials, compiled from the world's literature and critically evaluated. Developed under a worldwide program coordinated by NIST under the authority of the National Standard Data Act (Public Law 90-396). NOTE: The Journal of Physical and Chemical Reference Data (JPCRD) is published bimonthly for NIST by the American Chemical Society (ACS) and the American Institute of Physics (AIP). Subscriptions, reprints, and supplements are available from ACS, 1155 Sixteenth St., NW, Washington, DC 20056.

Building Science Series-Disseminates technical information developed at the Institute on building materials, components, systems, and whole structures. The series presents research results, test methods, and performance criteria related to the structural and environmental functions and the durability and safety characteristics of building elements and systems.

Technical Notes-Studies or reports which are complete in themselves but restrictive in their treatment of a subject. Analogous to monographs but not so comprehensive in scope or definitive in treatment of the subject area. Often serve as a vehicle for final reports of work performed at NIST under the sponsorship of other government agencies.

Voluntary Product Standards-Developed under procedures published by the Department of Commerce in Part 10, Title 15, of the Code of Federal Regulations. The standards establish nationally recognized requirements for products, and provide all concerned interests with a basis for common understanding of the characteristics of the products. NIST administers this program in support of the efforts of private-sector standardizing organizations.

Order the following NIST publications-FIPS and NISTIRs-from the National Technical Information Service, Springfield, VA 22161.

Federal Information Processing Standards Publications (FIPS PUB)—Publications in this series collectively constitute the Federal Information Processing Standards Register. The Register serves as the official source of information in the Federal Government regarding standards issued by NIST pursuant to the Federal Property and Administrative Services Act of 1949 as amended, Public Law 89-306 (79 Stat. 1127), and as implemented by Executive Order 11717 (38 FR 12315, dated May 11, 1973) and Part 6 of Title 15 CFR (Code of Federal Regulations).

NIST Interagency Reports (NISTIR)-A special series of interim or final reports on work performed by NIST for outside sponsors (both government and nongovernment). In general, initial distribution is handled by the sponsor; public distribution is by the National Technical Information Service, Springfield, VA 22161, in paper copy or microfiche form. 


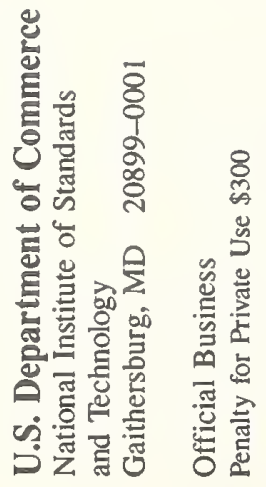

